\title{
FATORES ECOFISIOLÓGICOS AFETANDO O COMPORTAMENTO DE MILHO EM SEMEADURA TARDIA (SAFRINHA) NO BRASIL CENTRAL
}

\author{
FREDERICO OZANAN MACHADO DURÃES
}

Engenheiro Agrônomo

Orientador: Prof. Dr. JOSÉ DIAS COSTA

Tese apresentada à Escola Superior de Agricultura "Luiz de Queiroz", da Universidade de São, Paulo, para obtenção do título de Doutor em Agronomia, Área de Concentração: Fitotecnia.

PIRACICABA

Estado de São Paulo - Brasil

Julho - 1993 
Ficha catalográfica preparada pela Seção de Livros da Divisão de Biblioteca e Documentação - PCLQ/USP

\footnotetext{
Durães, Frederico Ozanan Machado

D947f Fatores ecofisiológicos afetando o comportamento de milho em semeadura tardia (safrinha) no Brasil Central. Piracicaba. 1993.

$91 \mathrm{p}$.

Tese - ESALQ

Biöliografia.

1. Milho - Comportamento 2. Milho - Ecofisiologia I. Escola Superior de Agricultura Luiz de Queiroz, Piracicaba 


\section{FATORES ECOFISIOLÓGICOS AFETANDO O COMPORTAMENTO DE MILHO EM SEMEADURA TARDIA (SAFRINHA) NO BRASIL CENTRAL}

FREDERICO OZANAN MACHADO DURĀES

Aprovada em: 23.08.1993

Comissão Julgadora:

Prof. Dr. Antônio Augusto Lucchesi USP/ESALQ

Prof. Dr. Antônio Luiz Fancelli USP/ESALQ

Prof. Dr. José Dias Costa USP/ESALQ

Dr. Osny Oliveira dos Santos Bacchi USP/CENA

Dr. Paulo César Magalhães EMBRAPA/CNPMS

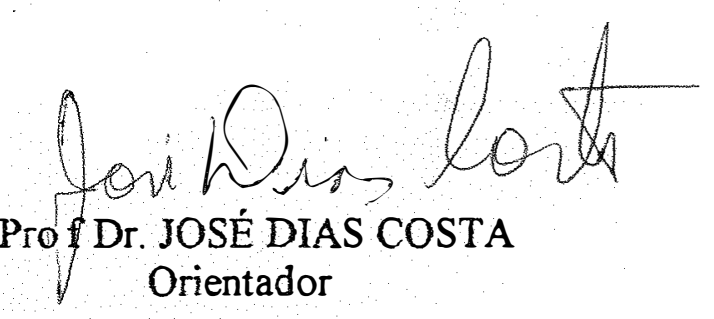


A Denise, Carolina, Frederico

e Viviane (in memoriam)

- esposa e filhos - dedico. 


\section{AGRADECIMENTOS}

- Aos Professores Doutores José Dias Costa e Antônio Luiz Fancelli, pela orientação e amizade.

- Ao colega embrapiano Doutor Paulo César Magalhães, pelo incentivo è amizade e pela sua participação na banca de tese.

- Aos membros da banca examinadora de tese, pelas críticas e sugestões.

- Aos colegas estudantes e funcionários do Departamento de Agricultura da ESALQ, USP, pelo bom convívio.

- Ao pessoal de apoio de campo e laboratório e ao grupo de estagiários do Departamento de Agricultura da ESALQ, USP, pela colaboração nas tarefas de coleta de dados.

- À minha esposa Denise e aos meus filhos Carolina e Frederico, pela presença e amor constantes e pelo estímulo necessário à realização integral deste curso de pósgraduação.

- À Empresa Brasileira de Pesquisa Agropecuária, ao Centro de Pesquisa Agroflorestal da Amazônia e à USP/Escola Superior de Agricultura "Luiz de Queiroz", pela oportunidade e facilidades oferecidas para a realização deste treinamento.

- Ao Centro Nacional de Pesquisa de Milho e Sorgo, da EMBRAPA, pela acolhida e pelas facilidades para análise dos dados e redação final da tese.

- A todos aqueles que colaboraram para a realização deste trabalho. 


\section{SUMÁRIO .}

Página

LISTA DE TABELAS viii

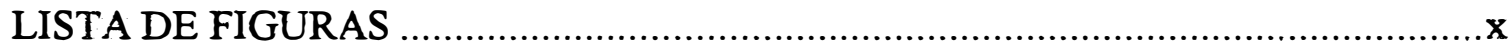

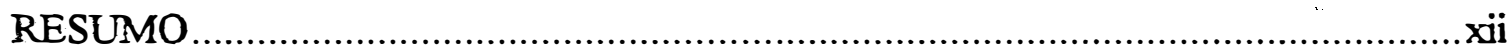

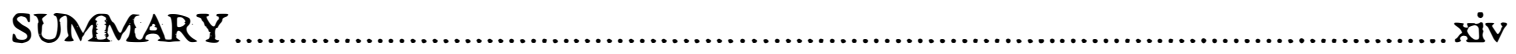

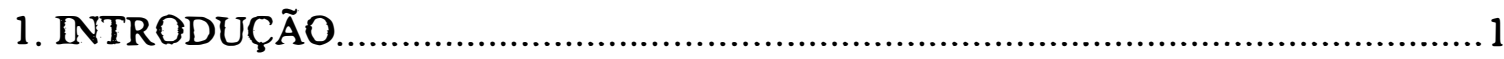

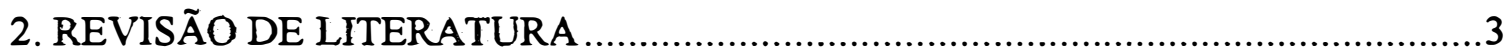

2.1. Fisiologia da produção do milho ...........................................................

2.2. Crescimento, rendimento e componentes do rendimento de cultivares de milho...5

2.3. Alocação diferencial de recursos em milho.................................................8

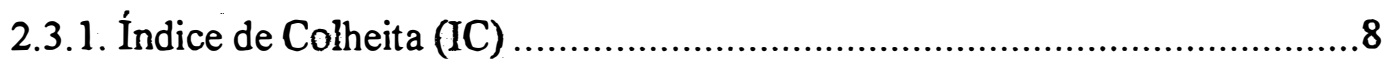

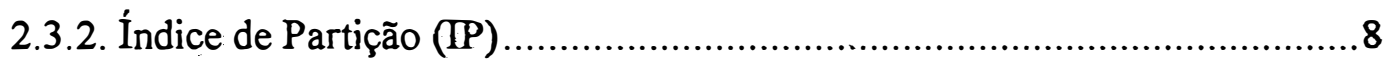

2.3.3. Índice de Esforço Reprodutivo (IER) ........................................... 9

2.4. Limitações do rendimento de grãos em milho tropical ...................................10

2.4. 1. Médias de rendimento regional .................................................. 10

2.4.2. Comparação de máximos rendimentos de grão .................................... 11

2.4.3. Rendimento como uma função da partição de fitomassa ......................... 11

2.4.4. Conceitos fisiológicos para incremento do rendimento de grãos ............. 13

2.4.4.1. Número de grãos ........................................................... 14

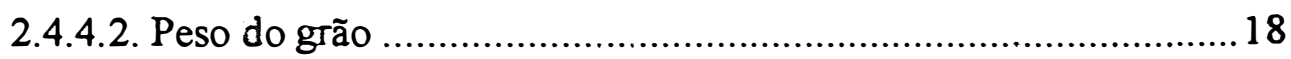

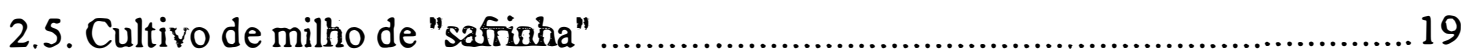

2.6. Somatório de Graus-dia (GD) acumulados no ciclo do milho .......................... 19

2.7. Metodologias em análise de crescimento vegetal ....................................21 


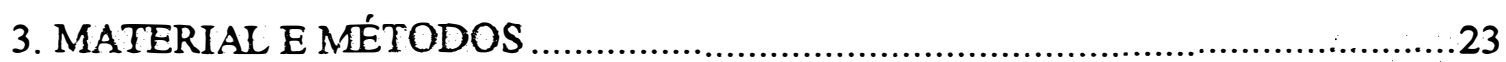

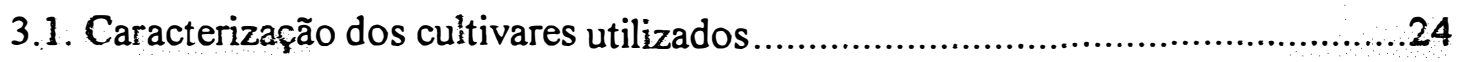

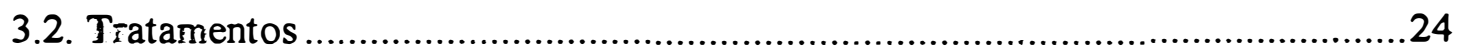

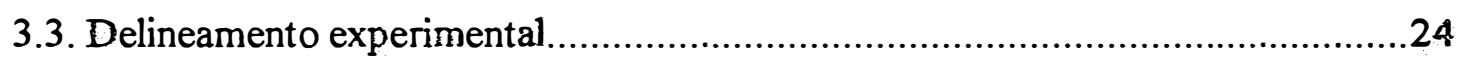

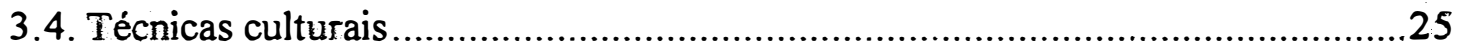

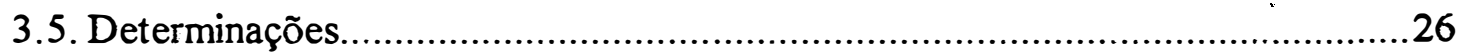

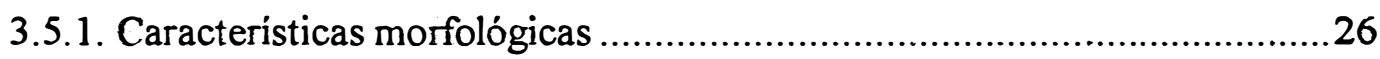

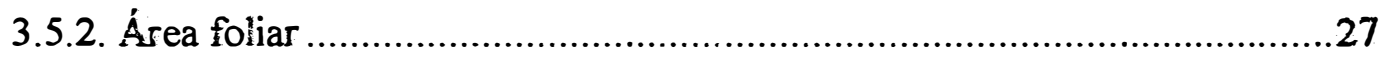

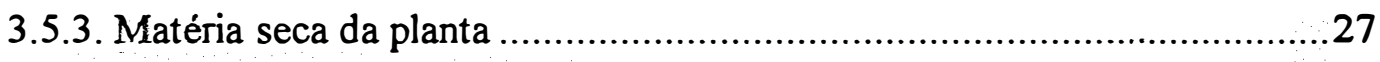

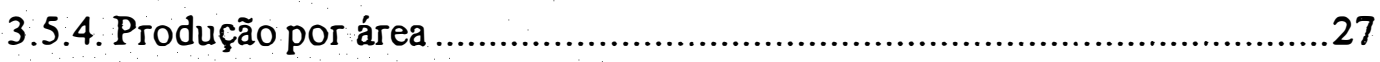

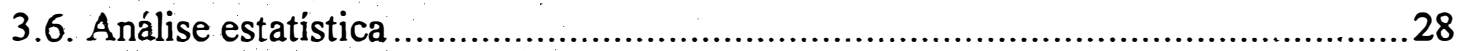

3.7. Obtenção de parâmetros fisiológicos.............................................................28

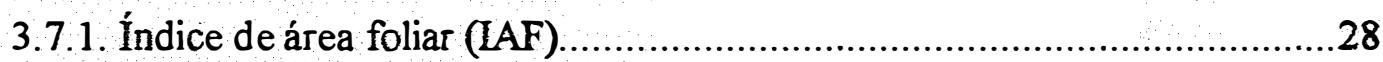

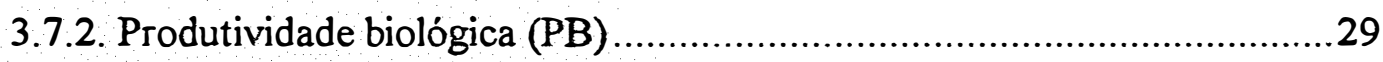

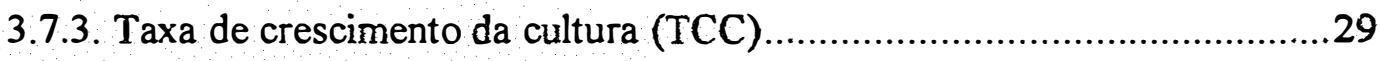

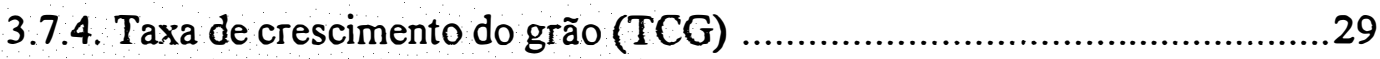

3.8. Obtenção de indices de colheita, de partição e de esforço reprodutivo ..............30

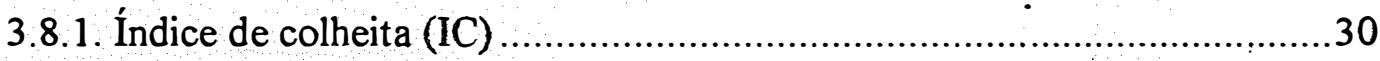

3.8.1.1. Estimativa do Índice de Colheita Genético (ICG) ......................30

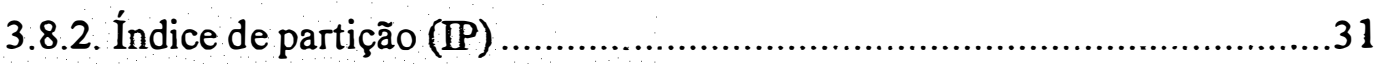

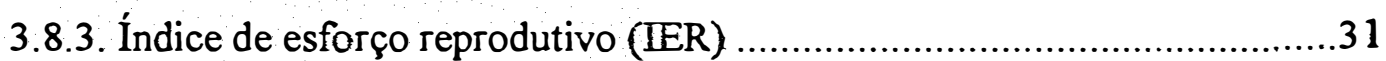

3.8.4. Interrelações do IC, IP e IER e suas relações com rendimento de grãos ..32

3.9. Obtenção de Graus-dia (GD) por subperiodo de desenvolvimento do milho: vegetativo e enchimento de grãos 


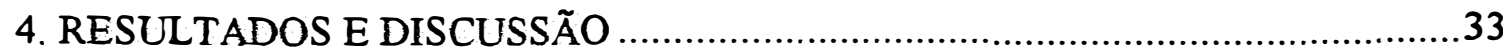

4.1. Matéria seca total da planta e de suas partes ..................................................33

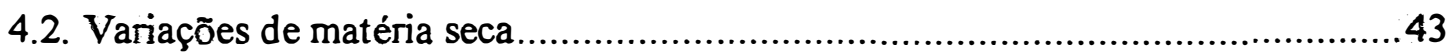

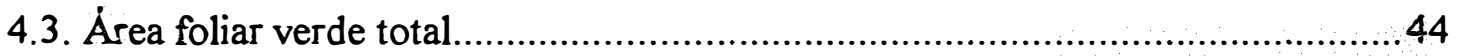

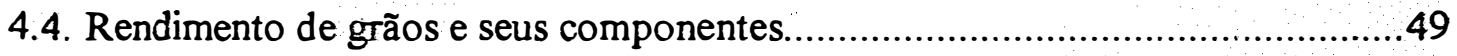

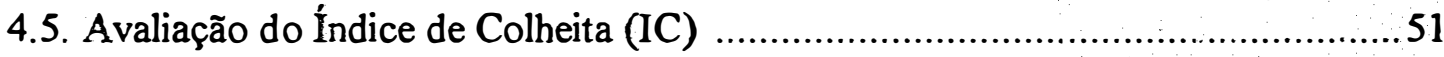

4.5.1. Avaliação do Índice de Colheita Genético (ICG) do milho .....................53

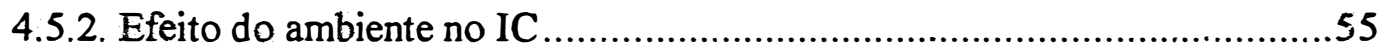

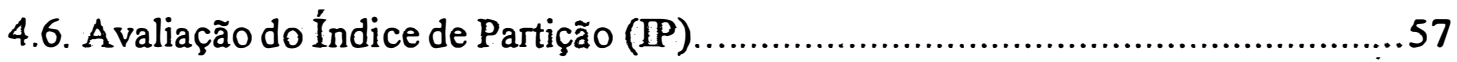

4.7. Avaliação do Índice de Esforço Reprodutivo (IER) ………………………......57

4.8. Interrelações do IC, IP e IER para milho e suas relações com o rendimento de

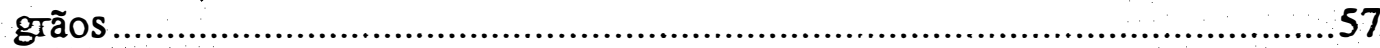

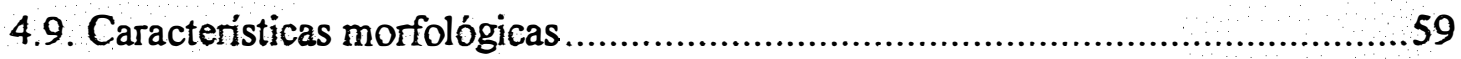

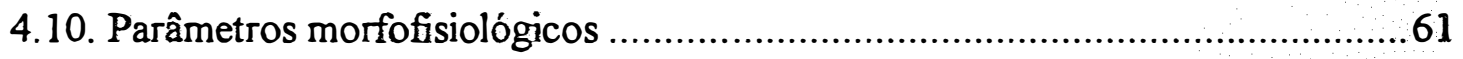

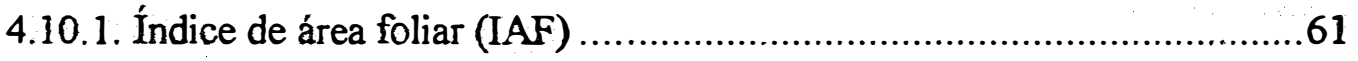

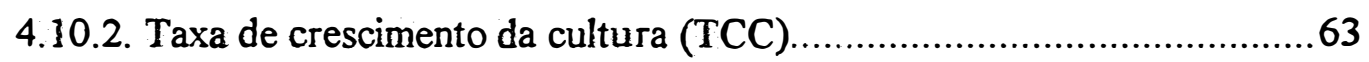

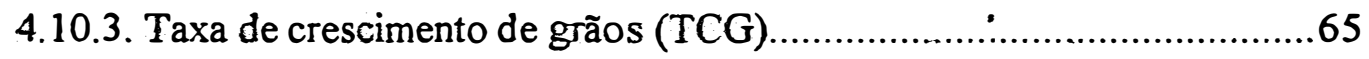

4.11. Graus-dia (GD) acumulados nos periodos vegetativo e enchimento de grãos...66

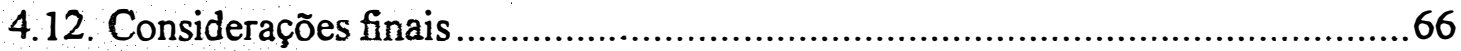

5. CONCLUSÃO

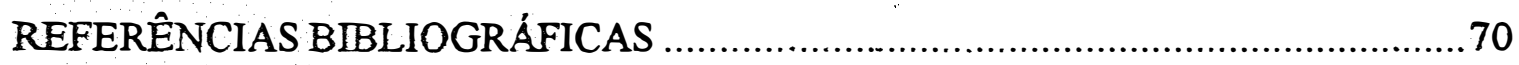

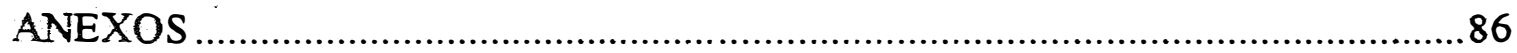




\section{LISTA DE TABELAS}

Página

Tabela 1 - Características dos cultivares de milho de diferentes ciclos............... 24

Tabela 2 - Adubação N, P, K utilizada para milho. Piracicaba, SP - fev./1992....

Tabela 3 - Matéria seca da planta total (MST) e dos grãos (MSG), relativa aos períodos de máximo acúmulo (máx.), no ponto de maturidade fisiológica (PMF), e aos 77 dias após a semeadura (77 DAS) de cultivares de milho de diferentes ciclos ( $\mathrm{cl}=$ Normal, $\mathrm{c} 2=$ Precoce, $\mathrm{c} 3=$ Superprecoce), em três densidades de cultivo de safrinha (d1 $=33,3 \mathrm{mil}, \mathrm{d} 2=55,5 \mathrm{mil}, \mathrm{d} 3=77,7 \mathrm{mil}$ plantas/ha). Piracicaba, SP. 1992

Tabela 4 - Porcentagem de matéria seca em relação ao máximo (g.m $\mathrm{m}^{-2} / \mathrm{g} \cdot \mathrm{m}^{-2}$ máx.) de folhas, durante o ciclo de cultivares de milho ( $\mathrm{cl}=$ Normal, c2 = Precoce, c3= Superprecoce), em três densidades de cultivo de safrinha $(\mathrm{d} 1=33,3 \mathrm{mil}, \mathrm{d} 2=55,5 \mathrm{mil}, \mathrm{d} 3=77,7 \mathrm{mil}$ plantas/ha). Piracicaba, SP. 1992

Tabela 5 - Valores estimados de área foliar verde total (média por planta $\mathrm{cm}^{2}$ ) em cultivares de milho de diferentes ciclos ( $\mathrm{cl}=$ Normal, $\mathrm{c} 2$ $=$ Precoce, $c 3=$ Superprecoce), em três densidades de cultivo de safrinha (d $=33,3 \mathrm{mil}, \mathrm{d} 2=55,5 \mathrm{mil}, \mathrm{d} 3=77,7 \mathrm{mil} \mathrm{plantas} / \mathrm{ha})$.

Piracicaba, SP. 1992.

Tabela 6 - Rendimento de grãos ( $\mathrm{kg} / \mathrm{ha}$ a $13 \%$ umidade), e componentes do rendimento, de cultivares de milho de diferentes ciclos $(\mathrm{cl}=$ Normal, c2 = Precoce, c3 = Superprecoce), em três densidades de cultivo de safrinha (d1 $=33,3$ mil, d2 $=55,5 \mathrm{mil}, \mathrm{d} 3=77,7 \mathrm{mil}$ plantas/ha). Piracicaba, SP. 1992.

Tabela 7 - Valores do Índice de Colheita (IC) de milho

Tabela 8 - Rendimento de grãos (kgha a 13\% de umidade) e valores de Índice de Colheita (IC), Índice de Partição (IP) e Índice de Esforço Reprodutivo (IER) de cultivares de milho de diferentes ciclos $(\mathrm{cl}=$ Normal, $\mathrm{c} 2=$ Precoce, $\mathrm{c} 3=$ Superprecoce), em três densidades de cultivo $(\mathrm{dl}=33,3 \mathrm{mil}, \mathrm{d} 2=55,5 \mathrm{mil}, \mathrm{d} 3=77,7 \mathrm{mil}$ plantas/ha). Piracicaba, SP. 1992. 
Tabela 9 - Altura de planta (AP, cm), número de folhas com limbo foliar completamente expandido (NFLE) e área foliar verde $\left(\mathrm{AF}, \mathrm{cm}^{2}\right.$ ), médias por planta, de cultivares de milho de diferentes ciclos (cl $=$ Normal, $\mathrm{c} 2=$ Precoce, $\mathrm{c} 3=$ Superprecoce), em três densidades de cultivo de safrinha $(\mathrm{d} 1=33,3 \mathrm{mil}, \mathrm{d} 2=55,5 \mathrm{mil}, \mathrm{d} 3=77,7 \mathrm{mil}$ plantas/ha), aos 77 DAS e no PMF. Piracicaba, SP. 1992.

Tabela 10 - Valores estimados de Índice de Área Foliar (IAF) de cultivares de milho de diferentes ciclos $(\mathrm{cl}=$ Normal, $\mathrm{c} 2=$ Precoce, $\mathrm{c} 3=$ Superprecoce), em três densidades de cultivo de safrinha ( $\mathrm{d} 1=$ 33,3 mil, d2 $=55,5 \mathrm{mil}, \mathrm{d} 3=77,7$ mil plantas/ha). Piracicaba, SP. 1992

Tabela 11 - Duração do crescimento e Taxa de crescimento da cultura (TCC) e dos grãos (TCG) de cultivares de milho de diferentes ciclos ( $c 1=$ Normal, $c 2=$ Precoce, $c 3=$ Superprecoce), em três densidades de cultivo de safrinha $(\mathrm{d} 1=33,3 \mathrm{mil}, \mathrm{d} 2=55,5 \mathrm{mil}$, $\mathrm{d} 3=77,7$ mil plantas/ha). Piracicaba, SP. 1992 


\section{LISTA DE FIGURAS}

Página

Figura 1 - Médias de temperatura do ar e precipitação mensal, de Fevereiro a Julho de 1992. Piracicaba, SP

Figura 2a - Acúmulo diferencial de matéria seca em cultivares de milho de diferentes ciclos $(\mathrm{cl}=$ Normal $)$, em três densidades de cultivo de safrinha $(\mathrm{d} 1=33,3 \mathrm{mil}, \mathrm{d} 2=55,5 \mathrm{mil}, \mathrm{d} 3=77,7 \mathrm{mil}$ plantas/ha). Piracicaba, SP. 1992

Figura $2 b$ - Acúmulo diferencial de matéria seca em cultivares de milho de diferentes ciclos ( $c 2=$ Precoce), em três densidades de cultivo de safrinha $(\mathrm{d} 1=33,3 \mathrm{mil}, \mathrm{d} 2=55,5 \mathrm{mil}, \mathrm{d} 3=77,7 \mathrm{mil}$ plantas/ha). Piracicaba, SP. 1992

Figura 2c - Acúmulo diferencial de matéria seca em cultivares de milho de diferentes ciclos $(c 3=$ Superprecoce), em três densidades de cultivo de saffinha $(\mathrm{dl}=33,3 \mathrm{mil}, \mathrm{d} 2=55,5 \mathrm{mil}, \mathrm{d} 3=77,7 \mathrm{mil}$ plantas/ha). Piracicaba, SP. 1992

Figura $3 a$ - Distribuição relativa sazonal de matéria seca $\left(\mathrm{g} / \mathrm{m}^{2}\right)$ em cultivares de milho de diferentes ciclos $(\mathrm{c} 1=$ Normal), em três densidades de cultivo de safrinha ( $\mathrm{dl}=33,3 \mathrm{mil}, \mathrm{d} 2=55,5 \mathrm{mil}, \mathrm{d} 3=77,7$ mil plantas/ha). Piracicaba, SP. 1992.

Figura 3b - Distribuição relativa sazonal de matéria seca $\left(\mathrm{g} / \mathrm{m}^{2}\right)$ em cultivares de milho de diferentes ciclos (c2 = Precoce), em três densidades de cultivo de safrinha $(\mathrm{d} 1=33,3 \mathrm{mil}, \mathrm{d} 2=55,5 \mathrm{mil}, \mathrm{d} 3=77,7$ mil plantas/ha). Piracicaba, SP. 1992.

Figura 3c - Distribuição relativa sazonal de matéria seca $\left(g / \mathrm{m}^{2}\right)$ em eultivares de milho de diferentes ciclos ( 3 = Superprecoce), em três densidades de cultivo de safrinha ( $\mathrm{d} 1=33,3 \mathrm{mil}, \mathrm{d} 2=55,5 \mathrm{mil}$, d3 = 77,7 mil plantas/ha). Piracicaba, SP. 1992

Figura 4a - Relação entre Índice de Área Foliar (IAF) e acúmulo de matéria seca total (MST) e de grãos (MSG), de cultivares de milho de diferentes ciclos $(\mathrm{cl}=$ Normal$)$, em três densidades de cultivo de safrinha $(\mathrm{d} 1=33,3 \mathrm{mil}, \mathrm{d} 2=55,5 \mathrm{mil}, \mathrm{d} 3=77,7 \mathrm{mil}$ plantas/ha). Piracicaba, SP. 1992

Figura 4b - Relação entre Índice de Área Foliar (IAF) e acúmulo de matéria seca total (MST) e grãos (MSG), de cultivares de milho de diferentes ciclos ( $c 2=$ Precoce), em três densidades de cultivo de safrinha $(\mathrm{dl}=33,3 \mathrm{mil}, \mathrm{d} 2=55,5 \mathrm{mil}, \mathrm{d} 3=77,7 \mathrm{mil}$ plantas/ha). Piracicaba, SP. 1992 
Figura 4c - Relação entre Índice de Área Foliar (IAF) e acúmulo de matéria seca total (MST) e de grãos (MSG), de cultivares de milho de diferentes ciclos ( $c 3=$ Superprecoce $)$, em três densidades de cultivo de safrinha $(\mathrm{dl}=33,3 \mathrm{mil}, \mathrm{d} 2=55,5 \mathrm{mil}, \mathrm{d} 3=77,7 \mathrm{mil}$ plantas/ha). Piracicaba, SP. 1992.

Figura 5 - Produções de matéria seca de grãos (MSG) e matéria seca total (MST), em $\mathrm{g} / \mathrm{m}^{2}$, de cultivares de milho de diferentes ciclos (c1 = Normal, $\mathrm{c} 2=$ Precoce, $\mathrm{c} 3=$ Superprecoce), em três densidades de cultivo de saffinha (d1 $=33,3 \mathrm{mil}, \mathrm{d} 2=55,5 \mathrm{mil}$, d3 = 77,7 mil plantas/ha). Piracicaba, SP. 1992. 


\title{
FATORES ECOFISIOLÓGICOS AFETANDO O COMPORTAMENTO DE MILHO EM SEMEADURA TARDIA (SAFRINHA) NO BRASIL CENTRAL
}

\author{
Autor: FREDERICO OZANAN MACHADO DURĀES \\ Orientador: Prof. Dr. JOSÉ DIAS COSTA
}

\section{RESUMO}

Objetivando-se avaliar as relações entre fonte de assimilados e grãodreno, bem como o comportamento de fatores morfofisiológicos que limitam o rendimento de grãos em plantas de milho (Zea mays L.) de diferentes ciclos (Nomal, Precoce e Superprecoce), em semeadura tardia (safiinha), foi conduzido, de fevereiro a julho/1992, na USP/ESALQ/Departamento de Agricultura, em Piracicaba, SP, um experimento com três densidades de cultivo $(\mathrm{d} 1=33,3 \mathrm{mil}, \mathrm{d} 2=55,5 \mathrm{mil}, \mathrm{d} 3=77,7 \mathrm{mil}$ plantas/ha).

Verificou-se a eficiência de cultivares de milho quanto à duração do crescimento e rendimento, nas fases vegetativa e reprodutiva. Esses parâmetros foram associados com o Índice de Colheita (IC, fração dos grãos em relação à matéria seca total da planta), Índice de Partição (IP, taxa de rendimento de grãos para a matéria seca produzida após o florescimento) e Índice de Esforço Reprodutivo (IER, razão entre a energia destinada aos órgãos reprodutivos e a energia total da planta). Os índices IC, IP e IER mostraram-se significativamente importantes na explicação do rendimento.

Os rendimentos de grãos variaram entre os cultivares e entre as densidades e foram significativamente superiores nas maiores densidades de cultivo, para os três cultivares avaliados. Valores máximos de IAF, dentro de cultivar, resultaram em maiores rendimentos de grãos e contribuíram para explicar a variação do acúmulo de matéria seca total e do grão.

Todos os cultivares tiveram o enchimento de grãos incompleto, indicando inadequada oferta de assimilados durante essa fase, principalmente para o cultivar superprecoce. Isto sugere que a oferta foi inferior à capacidade de 
armazenamento na espiga e, nesse caso, além do rendimento de grãos, outros órgãos vegetativos ficaram prejudicados em seu desenvolvimento.

Concluiu-se que as condições ambientais de cultivo de "safrinha" são subótimas para o desenvolvimento do milho, principalmente para os cultivares com características e comportamento de precocidade acentuada. Para esse tipo de cultivo de "safrinha", deve-se dar preferência a materiais que tenham larga capacidade de dreno e que acumulem rapidamente matéria seca em seus órgãos, continuando ainda a acumular, paralelamente ao enchimento de grãos, matéria seca total. A redistribuição de assimilados após o início do período de enchimento de grãos é uma característica desejável. 


\title{
ECOPHYSIOLOGICAL FACTORS AFFECTING MAIZE IN LATE SUMMER PLANTING ("SAFRINHA") IN CENTRAL BRAZIL
}

\author{
Author: FREDERICO OZANAN MACHADO DURĀES \\ Adviser: Prof. Dr. JOSÉ DIAS COSTA
}

\section{SUMMARY}

The objective of this work was to evaluate the source/sink relationships, as well as the effects of morphophysiological factors that limit the grain yield of maize (Zea mays L.) plants of different cycles (normal, early and very early) planted in late summer ("safrinha"). This study was conducted from February thru July/1992 at USP/ESALQ/Agriculture Department in Piracicaba, SP. This trial included three plant populations $(33,3,55,5$ and 77,7 thousand plants/hectare).

Cultivars efficiency related to duration of growth and yield was evaluated, in the vegetative and reproductive phases. These parameters were associated with Harvest Index (HI, ratio of grain dry weight to total above ground dry weight), Partition Index (PI, ratio of grain yield to dry matter produced after flowering) and Reproductive Effort Index (REI, ratio between the energy of reproductive parts to total plant energy). All of indexes were significantly important and helped to explain the grain yield variable.

The grain yield varied among cultivars and populations and the best yields were found in the highest plant population for all cultivars. The LAI maximum values within cultivars resulted in high grain yields and contributed greatly to total dry matter accumulation in the plant and grain.

All the cultivars had the grain filling duration incompleted, which indicates low offer of assimilates during this stage, especially for a very early cultivar. This suggest that source was lower than the capacity of the sink and in this case, besides grain yield, other vegetative parts were injured in its development. 
Environmental conditions for cultivating "safrinha" are not the best for development of maize plant, mainly for genotypes with characteristics of very early cycle. For this type of planting ("saffinha") preference should be given for materials that have great grain capacity and fast dry matter accumulation in its organs. The assimilate redistribution after the beginning of grain filling is also a desirable characteristic. 


\section{INTRODUÇÃO}

A agricultura no Brasil Central tem-se caracterizado pelo cultivo de uma saffa durante o ano, no período de primavera-verão.

No período de entressafra (outono-inverno), a falta de plantio, aliada à ociosidade da infra-estrutura de armazéns, máquinas e equipamentos e mão-de-obra, com reflexos econômicos negativos, tem levado várias regiões a repensarem suas atividades agropecuárias.

As opções de culturas economicamente viáveis e adaptadas para o período de entressafra estão restritas a poucas culturas, como o cultivo de trigo, feijãoda-seca e aveia. Isto é considerado muito pouco para os produtores que possuem um alto capital empregado na exploração da agricultura.

Nos estados do Paraná e São Paulo, a cultura do milho vem se tornando uma alternativa de cultivo para o período de fevereiro a agosto. Mesmo considerando o risco característico das culturas de entressafra, a prática do cultivo do milho em sucessão às culturas de primavera-verão permite a colheita de uma segunda safra no mesmo àno agrícola, protege o solo durante o período de inverno, proporciona melhor utilização da terra, da maquinaria e da mão-de-obra. Propicia, ainda, uma rentabilidade adicional ao produtor rural. A colheita do milho "safininha" coincide com a entressafra de oferta do produto, existindo maiores possibilidades do agricultor conseguir preços mais compensadores para o produto (GERAGE \& BIANCO, 1987; EMPAER Fato Rural, 1993). 
Por se tratar de atividade de maior risco, muitos produtores de milho "safrinha" ainda usam medidas tecnológicas de baixo custo, acarretando baixas produtividades. O plantio de grãos provenientes da segunda geração dos híbridos cultivados na safra normal, o aproveitamento da adubação residual da cultura anterior, e controle mecânico de plantas daninhas são práticas que devem ser substituidas para o aumento de produtividade do milho saffinha. Entretanto, ainda, carece de informações adequadas sobre a recomendação de cultivares de milho preferenciais para cada região, para essa época de semeadura.

Os cultivos de milho de safrinha geralmente rendem menos que em período normal, necessitando melhorias e identificações das respostas fisiológicas limitantes.

Avaliou-se a relação entre fonte de assimilados (folhas) e grão-dreno, buscando-se fatores que limitam o rendimento de grãos em plantas de milho. Procurou-se determinar, entre os cultivares de milho utilizados, se fonte (superficie foliar) ou tamanho do dreno (grão) limitam o rendimento; se há ou não competições entre partes vegetativa e reprodutiva das plantas; se esta é a causa principal que limitou a capacidade de dreno dos cultivares; bem como, comparou-se as respostas fisiológicas entre eles. Verificou-se a eficiência dos cultivares, quanto à duração do crescimento e rendimento, nas fases vegetativa e reprodutiva. Esses parâmetros foram associados com o Índice de Colheita (IC), Índice de Esforço Reprodutivo (IER, razão entre a energia destinada aos órgãos reprodutivos e a energia total da planta), e Índice de Partição (IP, taxa de rendimento de grãos para a matéria seca produzida após o florescimento). 


\section{REVISÃO DE LITERATURA}

\subsection{Fisiologia da produção do milho}

O milho (Zea mays L.) apresenta caracteristicas fisiológicas favoráveis à eficiência de conversão do carbono mineral em compostos orgânicos (WILLIAMS et al., 1965; GIFFORD \& EVANS, 1981).

Os produtos da assimilação do dióxido de carbono atmosférico são constantemente translocados no interior da planta - das folhas e outros tecidos fotossinteticamente ativos (fonte) para locais onde são consumidos ou estocados (dreno), e dos depósitos de armazenagem para zonas de crescimento e frutos (cariopse).

Uma pequena fiação dos carboidratos produzidos pela fotossintese permanecem acumulados nos sítios de sua produção, representados principalmente pelas folhas expandidas. A maior parte é transportada para outras partes da planta, que se constituem em sítios de consumo e, alternativa ou simultâneamente, em sítios de acumulação. Parte dos carboidratos é perdida por respiração, durante o processo de transporte e no próprio órgão de armazenamento.

O transporte dos produtos fotossintetizados obedece a padrões bem estabelecidos, dependendo da morfologia da planta. No milho, o mais intenso sítio de consumo dos produtos de fotossintese ocorre durante a fase reprodutiva, e é representado pelos grãos em processo de rápido crescimento (ALLISON \& WATSON, 1966). 
O eficiente transporte de materiais, produzidos e acumulados nas folhas, em direção aos grãos em formação, é de grande importância para garantir alta produção.

Um caráter importante na determinação da eficiência de produção de grãos é a extensão da área foliar que permanece fisiologicamente ativa após a emergência da espiga. Assim, a produtividade da planta de milho pode ser correlacionada com a duração da área foliar (DAYNARD et al., 1971). Entretanto, variedades de milho podem apresentar diferentes características de produção de grãos em função do tempo ocorrido desde a antese até a fase de senescência das folhas.

A maior eficiência fotossintética das variedades altamente produtivas é decorrência mais pelo incremento da intensidade fotossintética do que pelo aumento da capacidade fotossintética, que está associada com a superficie total dos órgãos que realizam fotossíntese. Produções crescentes estão associadas com a obtenção de valores mais elevados de intensidade fotossintética e a um transporte mais eficiente dos produtos fotoassimilados para o órgão colhido - grãos (TOLLENAAR \& DAYNARD, 1977).

Com base em pesquisa do crescimento compensatório e padrões de partição de carbono, pesquisadores tem sugerido que órgãos-drenio na planta competem por uma oferta limitada de carbono assimilado. Essa idéia é consistente com o entendimento de que assimilados são transportados para órgãos-dreno via uma interconexão dos tubos crivados floemáticos, e então, todos os órgãos-dreno tem acesso a um pool comum de assimilados em órgãos-fonte. Como em outras situações competitivas, entretanto, o fluxo de saída de assimilados deve ser determinado não apenas pela competição direta por recursos, mas também pelos fatores indiretos, tais como aqueles que regulam a taxa de transporte e metabolismo dos tecidos de fonte e de dreno (SETTER, 1986). 


\subsection{Crescimento, rendimento e componentes do rendimento de cultivares de milho}

O rendimento de grãos em cultivos de milho é uma função de inúmeros fatores e processos atuando concorrentemente, quais sejam: interceptação de luz pela cobertura vegetal da cultura, eficiência metabólica das plantas, eficiência de translocação de fotossintatos das folhas para os grãos em crescimento e capacidade do dreno. As relações de fonte e dreno são função de condições ambientais (WILSON et al., 1973; TOLLENAAR, 1977).

A importância relativa desses fatores e processos não é amplamente conhecida para os diferentes cultivares, sobretudo em condições de manejo distintas daquelas nas quais cada cultivar foi selecionada pelo melhoramento genético. Toma-se importante identificá-los, a fim de que os rendimentos de cada cultivar possam ser incrementados, em relação aos seus niveis atuais.

Entender a natureza do acúmulo de matéria seca durante a estação de crescimento, bem como a partição da matéria seca para o grão e outros componentes da planta pode direcionar para o incremento do rendimento de grãos, através do melhoramento (genético e do manejo) de plantas.

Rendimento de grãos de uma cultura pode ser expresso como o produto do rendimento biológico e índice de colheita (DONALD \& HAMBLDN, 1976). Rendimento biológico, comumente medido pelo peso total da matéria seca da planta, é uma medida integrada dos efeitos combinados da fotossintese e respiração durante a estação de crescimento. Fotossíntese, por sua vez, é dependente da extensão da área foliar e da duração da superficie das folhas verdes (LOOMIS \& WLLIAMS, 1963).

Rendimentos de milho tem sido aumentados pela melhoria da eficiência da interceptação de luz (WILLIAMS et al., 1968), pela melhoria da distribuição da luz através de reduzido espaço de fileiras (LAMBERT \& JOHNSON, 1978), e pela melhoria 
da redistribuição de luz para partes mais baixas da copa pela alteração da arquitetura da copa (PEPPER et al., 1977). Tem-se procurado, ainda, alterar componentes do rendimento, tal como aumento da prolificidade - capacidade de dreno (DUVICK, 1974).

Os fatores envolvendo o rendimento de grãos podem ser simultaneamente sumarizados na seguinte equação:

$$
\mathrm{RG} / \mathrm{A}=\mathrm{AF} / \mathrm{A} \times \mathrm{NG} / \mathrm{AF} \times \mathrm{PG}
$$

onde,

$\mathrm{AF} / \mathrm{A}=\mathrm{IAF}$ (mede a eficiência da interceptação de luz)

$\mathrm{NG} / \mathrm{AF}=$ tamanho do dreno

$P G=$ quantidade de fotossintatos armazenados nos grãos

RG $=$ Rendimento de grãos

$\mathrm{A}=$ Área do terreno

$\mathrm{AF}=$ Área Foliar

$\mathrm{NG}=$ Número de grãos

$P G=$ Peso de grãos

IAF $=$ Índice de Área Foliar

$O$ produto do NG/AF e PG é a eficiência de rendimento, que é uma função da eficiência fotossintética na produção de grãos, se toda a matéria seca produzida após antese é translocada para o grão em crescimento (enchimento de grão), ou é uma função da eficiência de translocação, em outros casos. 
DONALD (1962) e DONALD \& HAMBLIM (1976) enfatizaram a utilização do Índice de Colheita (IC, fração dos grãos em relação à matéria seca total da planta) no contexto agronômico e por fitomelhoristas para o aumento do rendimento de culturas. Segundo SNYDER \& CARLSON (1984) a síntese, translocação, partição e acúmulo de produtos fotoassimilados na planta são controlados geneticamente e influenciados por fatores ambientais.

Estudos, como os de STOCKLE \& CAMPBELL (1985) tem mostrado que IC de uma cultura é marcadamente influenciado pela densidade de plantio, disponibilidade de água e nutrientes, e temperatura na estação de crescimento. Isto torna dificil as comparações entre cultivares, para IC. Valores de IC obtidos sob condições ambientais adversas podem mascarar a performance de cultivares em favor de outras, em condições ambientais diferentes.

Face a esses comportamentos de cultivares, PRIHAR \& STEWART (1990) propuseram que as comparações entre cultivares (e entre espécies) poderiam ser baseadas no Índice de Colheita Genético (ICG). A hipótese básica para a prescrição de um procedimento para estimar o ICG de um cultivar é oue IC está diretamente relacionado com a partição de fotoassimilados para o rendimento econômico, e é um parâmetro relacionado à espécie, de acordo com SNYDER \& CARLSON (1984). Assim, comparações entre cultivares poderiam ser baseadas nos IC que se aproximam do ICG sob determinadas condições ambientais. Dependendo da natureza e da extensão da condição ambiental, o IC observado de uma cultura desvia do ICG.

As plantas procuram se adaptar às condições de ambiente, usando estratégias de modificarem suas estruturas vegetativas e/ou reprodutivas, a depender do seu estádio de desenvolvimento. Adversidades ambientais, geralmente, redundam em menor IC. Plantas bem adaptadas poderiam produzir próximo de seu ICG. 


\subsection{Alocaf̧ão diferencial de recursos em milho}

\subsubsection{Indice de Colheita (IC)}

Índice de colheita de cereais é uma medida da eficiência da conversão de fotossintatos no rendimento econômico (DONALD, 1962). Há considerável interesse no uso do índice de colheita como um critério de seleção para a melhoria do rendimento em culturas de cereais. TEHLAN et al. (1979) argumenta que diferenças no padrão de produção de matéria seca pode ser relacionada com o rendimento final. Entretanto, JAIN et al. (1976) questionam se a produção de grãos é uma função da capacidade de produzir grandes quantidades de matéria seca ou, alternativamente, da sua habilidade de dividir a matéria seca entre os órgãos e as outras partes da planta. Um cultivar será eficiente, portanto, quando combinar alta produção de matéria seca com a capacidade de dividi-la entre os componentes econômicos e os demais componentes (FRANCIS et al., 1978; FREY, 1981).

SNYDER \& CARLSON (1984), analisando a seleção para partição de fotossintatos, observaram que o índice de colheita é um importante parâmetro para a medida da produção econômica. Advertem, porém, que seu conhecimento deve estar associado à identificação dos componentes fisiológicos que afetam a produção econômica.

\subsection{2. Índice de Partição (IP)}

Fatores ambientais que limitam a adaptação de cultivares de milho interferem, de forma significativa, no rendimento de grãos. Esse rendimento tende a ser limitado por processos que influenciam a oferta de assimilados no período de enchimento de grãos e/ou processos que controlam o desenvolvimento do dreno-grão. Diferenças de rendimento de grãos entre materiais de milho de diferentes ciclos são, com frequência, 
examinados em termos da diferença entre produção total (palhada e grãos) e a partição dessa matéria seca para o grão (Índice de Colheita). Embora seja um índice de construção prática, não favorece a identificação de respostas fisiológicas limitantes. DURĀES et al. (1993) avaliaram, comparativamente, as diferenças entre padrões de acúmulo e partição de matéria seca de cultivares de milho de diferentes ciclos de cultivo. Foram verificadas as eficiências das cultivares, nas fases vegetativa e reprodutiva, quanto aos fatores fisiológicos de fonte (índice de superficie foliar) e os fatores de conversão (número de grãos por unidade de superficie, peso do grão) - que poderiam limitar os rendimentos. Esses parâmetros foram associados ao índice de colheita e à taxa de rendimento de grãos para a matéria seca produzida após florescimento (Índice de Partição). As características morfofisiológicas que se associaram com o alto rendimento de grãos variaram para os diferentes cultivares. Precocidade conferiu maiores índices de partição.

\subsubsection{Indice de Esforço Reprodutivo (IER)}

Em situações em que os indivíduos de uma comunidade competem por recursos materiais e energéticos, deverão sobreviver aqueles que possuirem características adaptativas superiores (morfológicas, fisiológicas e comportamentais). A habilidade de dividir recursos entre a reprodução, sobrevivência, crescimento e proteção é uma das características adaptativas importantes, definida pelo "princípio de alocação" de CODY (1966). De todos os recursos disponíveis, aqueles destinados à reprodução podem ser quantificados através do Esforço Reprodutivo (ER), definido por HIRSHFIELD \& TINKLE (1975) como a proporção da energia total que um organismo destina à reprodução, num intervalo de tempo específico e biologicamente significativo. 
O Índice de Esforço Reprodutivo (IER) é dado pela razão entre a energia destinada aos órgãos reprodutivos e a energia total da planta.

Esforço reprodutivo pode ser medido pela determinação da fitomassa seca (HARPER \& OGDEN, 1970) ou pelo método da calorimetria (PAINE, 1971). Estudos comparativos entre os dois métodos, realizados por HICKMAN \& PITELKA (1975), levam à conclusão de que não há diferença significativa entre os resultados obtidos, desde que o tecido vegetal analisado não possua elevada proporção de lipídios. Com base nesses resultados e na maior facilidade de execução, o método da fitomassa seca tem sido o mais utilizado para o cálculo do esforço reprodutivo.

\subsection{Limitações do rendimento de grãos em milho tropical}

\subsubsection{Médias de rendimento regional}

Diferenças de rendimento de milho podem refletir o nivel de práticas agronômicas nas regiões. Problemas de fertilidade do solo, doenças de plantas, insetos, plantas daninhas, disponibilidade de umidade, e uma tendência para os extremos no clima em áreas tropicais; além de cultivos de subsistência, em condig̨ões precárias ou em associação com outros cultivos, podem explicar a variação nos rendimentos, em geral baixos.

Aumentos no rendimento podem ocorrer devido à melhor administração agro-econômica dos cultivos; entretanto, em patamares de produtividade mais elevados, os incrementos no rendimento devem passar pelo melhoramento genético, objetivando produtividade e/ou tolerância aos estresses. 


\subsubsection{Comparação de máximos rendimentos de grão}

Em áreas tropicais, a maioria dos altos rendimentos são restritos em áreas intermediárias ou de alta altitude tendo longas estações chuvosas. Segundo FISHER \& PALMER (1983), citando diversos autores, rendimentos de 12 tha tem sido obtidos em latitude $18^{\circ} \mathrm{Sul}$, altitude $1.500 \mathrm{~m}$ (Rodésia-Zimbabwe). Em terras baixas tropicais, rendimentos podem atingir 5 a 8 tha, com boa administração.

Em regiões temperadas, rendimentos máximos em torno de 20 tha são relatados. Rendimentos comerciais de 10 t/ha são comuns (FREY, 1971).

Diferenças no rendimento de grãos não são sempre causadas por diferenças na duração do cultivo, medidas em dias ou em acumulação de unidades de calor. Nas regiões tropicais, onde é menor a variação de temperatura, umidade é fator preponderante. A produção é influenciada pela disponibilidade de água no solo, especialmente na fase que antecede o pendoamento (MUNDSTOCK, 1970).

\subsubsection{Rendimento como uma função da partição de fitomassa}

Diferenças de rendimento de grão entre cultivares pode ser avaliada em termos da diferença entre produção biológica total e a partição dessá matéria seca para o grão (Índice de Colheita e Índice de Partição).

EVANS (1975) relatou que a rota fotossintética de culturas tais como o milho produz vantagens quanto ao crescimento em ambientes tropicais, por causa de mais altos pontos ótimos de temperatura para fotossíntese, a ausência de fotorrespiração e uma favorável taxa de transpiração.

STEWART (1970) concluiu que, pelas inovações agronômicas (incluindo esforços integrados na manipulação de genótipos para vários ambientes tropicais), algumas áreas podem sobrepujar outras em produção através de uso criterioso 
de monocultivo, cultivo múltiplo, ou rotação de culturas. Concluiu ainda, que produção de fitomassa total em ambientes tropicais não é um fator limitante para o rendimento, como apontam GOLDSWORTHY et al. (1974).

YAMAGUCHI (1974) e GOLDSWORTHY et al. (1974) atribuiram o baixo rendimento de grãos, em regiôes tropicais, à deficiente partição da matéria seca para o grão.

Ein áreas tropicais abaixo de $1.000 \mathrm{~m}$ de altitude, a planta de milho acumula considerável matéria seca no colmo, bainhas de folhas, sabugo e brácteas após florescimento. Parte dessa matéria seca é translocada para o grão mais tarde, no período de enchimento de grãos (PALMER et al., 1973). Resultados experimentais relatados por GOLDSWORTHY et al. (1974) apontam que o rendimento de milho é limitado principalmente pelo tamanho do grão-dreno, embora sob algumas perdas ambientais de área foliar (fonte) próximo da maturidade pode reduzir o rendimento de grãos.

Milhos tropicais geralmente tem maturação tardia, porte alto, frondoso, e grande pendão. Eles mostram um nivel maior de dominância apical, baixo índice de colheita, e são menos eficientes em retranslocar para os grãos a matéria seca previamente depositada no colmo. Segundo EVANS (1975), tais caracteristicas devem ter sido importantes para a adaptação do milho aos ambientes tropicais. Materiais de milho de porte alto, apresentando enfolhamento adequado, poderiam competir com plantas de rápido crescimento, e também o efeito da perda de folha por insetos poderia ser minimizado. Reservas de açúcares no colmo pode ser, evolutivamente, resultado da resistência à seca e pode ter sido associada com resistência para podridões da haste. $\mathrm{O}$ crescimento vegetativo do milho em áreas tropicais também pode ser importante quanto à nutrição nitrogenada da cultura. 
Em altitudes supenores a $1.000 \mathrm{~m}$, os cultivares de milho tropical apresentam a duração do crescimento mais longa que em terras baixas tropicais e é limitado ou por baixas temperaturas ou disponibilidade de umidade para plantio (WILSON et al., 1973).

Embora os rendimentos em terras altas tropicais sejam maiores que aqueles em terras baixas tropicais, GOLDSWORTHY \& COLEGROVE (1974) e YAMAGUCHI (1974) concluiram que rendimentos em ambas as áreas foram limitadas pela capacidade do grão-dreno em acumular fotoassimilados.

Algumas dessas diferenças em partição são devido ao ambiente e interação genótipo x ambiente. Há, entretanto, consideráveis variações genéticas quando diferentes genótipos crescem em um mesmo ambiente. Por causa da sensibilidade ao fotoperiodo de genótipos tropicais, uma comparação não pode ser feita em ambientes temperados.

Segundo BADU-APRAKU et al. (1983), redução no rendimento está associado com um período de enchimento de grãos mais curto. Durante um rápido enchimento de grãos, o aumento na matéria seca do grão resulta da utilização dos efeitos combinados de assimilados temporariamente estocados em partes vegetativas da planta e produzidos através da fotossíntese. Em altos regimes de temperatura diuma/noturna a acumulação de matéria seca durante o enchimento de grãos é reduzida. Rendimentos de grãos por planta também é menor sob altas temperaturas.

\subsubsection{Conceitos fisiológicos para incremento do rendimento de grãos}

A cultura do milho é considerada um sistema eficiente para converter a energia luminosa em matéria seca do grão, se bem que esse enfoque de incremento do 
rendimento do grão, pode estar negligenciando outras partes da planta economicamente importantes.

O genótipo influencia a quantidade de energia fixada, bem como sua distribuição para as várias partes da planta. O rendimento de grão em uma dada área é considerado em seus componentes número de grãos por unidade de área $\mathrm{x}$ tamanho (e peso) de grão. Alguns processos fisiológicos são envolvidos para determinar esses componentes, e devem ser explorados para mudanças genéticas, visando melhoria do rendimento.

\subsubsection{Número de grãos}

Número de grãos por planta e por unidade de área de terreno depende amplamente de eventos antes e na época do florescimento. Em áreas tropicais, este é o componente de rendimento que normalmente concorre para maiores variações no rendimento entre genótipos (YAMAGUCHI, 1974). Segundo esse autor, número final máximo de grãos por planta foi encontrado em ambientes onde a temperatura média foi máximo $30^{\circ} \mathrm{c}$ e mínimo $13,5^{\circ} \mathrm{c}$, durante o estágio de desenvolvimento da iniciação floral até florescimento. Esse efeito foi, provavelmente, da influência da temperatura na taxa de desenvolvimento da cultura. Houve forte relação entre número de grãos colhidos e a radiação total acumulada durante o estágio de desenvolvimento (da iniciação até florescimento); e, número de grãos foi relativamente independente da intensidade de radiação durante o período. Diferenças no rendimento de grãos são atribuidas às diferenças na média do peso de grãos. Os efeitos de temperatura no peso de grão e rendimento de grãos são associados com diferenças na duração do enchimento de grãos.

TOLLENAAR (1977) revisou o controle do desenvolvimento de fonte e dreno em milho e concluiu que a irradiância interceptada pela planta durante o florescimento foi o fator dominante determinando o número de grãos. Número de grãos 
foi influenciado pela taxa de crescimento da cultura no estágio crítico, pela partição da matéria seca para a espiga, e pelo fator fertilidade das espigas (grãos potenciais).

\section{a) Taxa de crescimento da cultura}

Evidências experimentais sugerem que esforços para incrementar rendimento de grãos através do incremento da produção de assimilados deverão enfocar o periodo ao redor do florescimento (cerca de 10 a 15 dias, antes e depois). PRINE (1971) identificou esse estágio de desenvolvimento como um período crítico para o desenvolvimento da espiga.

Maiores reduções no rendimento e diferentes respostas genéticas são devidas aos efeitos que, por fim, reduzem o número de grãos por planta, como medida da colheita.

\section{b) Partição de matéria seca}

Durante o período crítico de crescimento, para determinar número de grãos, há crescimento simultâneo de outras partes da planta. Nesse estágio, a matéria seca na espiga é afetada mais que outras partes da planta pela redução da fotossintese. Reduzindo o tamanho de alguns outros órgãos deve-se' permitir um maior particionamento da matéria seca para a espiga.

Despendoamento do milho, por exemplo, incrementa o rendimento de grãos (DUNCAN et al., 1967; FANCELLI, 1988; MAGALHÃES, 1993).

Em milho tropical crescendo sob diferentes niveis de estresse de nitrogênio, água e densidade de plantas, a remoção do pendão antes do florescimento incrementou o rendimento de grãos de 9,5, 21,0 e 17,9\%, respectivamente (POEY et al., 1977). 
MESSIAEN (1963) demonstrou que milho difere de outros cereais, e que espiga cresce de uma gema axilar e está sujeita à dominância apical; portanto, baixa atividade metabólica do pendão antes da antese pode aumentar o crescimento da espiga.

O crescimento foliar continua no espigamento, ou logo após (HANWAY, 1962), mas faltam evidências que o crescimento foliar influencia o crescimento da espiga durante o período crítico do crescimento. Entretanto, há evidências de que o rendimento de grãos (e consequentemente número de grãos) aumenta com aumentos de IAF, com valores variando de 3 para 5, no Corn Belt americano, segundo EIK \& HANWAY (1966) e em condições tropicais (YAMAGUCHI, 1974).

Em materiais tropicais, alguma redução no tamanho da folha (daquelas folhas crescendo durante o período crítico de crescimento - drenos competitivos no interior da planta) pode ser benéfica, porque folhas de milho são uma importante fonte de assimilados, durante grande parte de sua ontogenia (KIRBY, 1973; ALLISON et al., 1975; WRIGHT et al., 1988).

EASTEN (1969) estudou a importância relativa das folhas em diferentes posições na planta em prover assimilados para a espiga crescendo no Com Belt. O interesse principal é a relação específica entre posição da folha e sua contribuição para o crescimento da espiga, por época do espigamento. Dentre as folhas próximas da espiga, a folha dominante contribui para o crescimento da espiga até esse estágio; entretanto, o padrão varia entre genótipos.

Oferta de fotoassimilados para o desenvolvimento da espiga, nutrição nitrogenada e balanço hormonal podem influenciar esses efeitos de iluminação em folhas específicas, determinando o número de grãos durante o período crítico de crescimento. 


\section{c) Fertilidade das espigas (grãos potenciais)}

O número de óvulos presentes na época do florescimento representa o número de grãos potenciais que, entretanto, podem ser reduzidos por eventos posteriores ao florescimento (DERIEUX et al., 1983). Segundo Fuchs (1968), citado por DERIEUX et al. (1983), existe uma relação entre o número de óvulos e precocidade. Os resultados indicam que número de óvulos inicial é altamente correlacionado com a superficie foliar no início da diferenciação e que genótipo influenciou mais que o fator ambiental temperatura.

Milho tem potencial morfológico para produzir mais de uma espiga. Segundo HALLAUER \& TROYER (1972) o desenvolvimento da primeira e segunda espigas é similar para um período crítico próximo do florescimento, após o qual a segunda espiga aborta. Os mecanismos que controlam prolificidade são provavelmente relacionados com aqueles envolvidos em esterilidade.

Evidências experimentais apontam que aborto de espiga está relacionado com competição intraplanta por fotoassimilados, durante o período crítico de crescimento. EDMEADES \& DAYNARD (1979) sugeriram que a relação entre número de grãos e taxa de assimilação ao florescimento pode ser curvilíneo com o nível de rendimento de grão atingindo zero (esterilidade) para um pequeno limiar da taxa de assimilação líquida.

STINSON \& MOSS (1980) apresentaram alguns exemplos de diferenças entre genótipos e o grau de plantas estéreis sob condições de estresse, tais como competição por luz. Segundo HALLAUER \& TROYER (1972), essas diferenças parecem estar associadas com prolificidade.

Grãos que abortam são normalmente os mais jovens, no topo do sabugo da espiga. TOLLENAAR \& DAYNARD (1978) mostraram que esses grãos 
foram fertilizados e começaram crescimento normal. Entretanto, no princípio há um rápido acúmulo de matéria seca pelos grãos mais velhos abaixo no sabugo, e os grãos superiores abortam. Aborto ocorre a despeito da relativamente alta concentração de açúcares solúveis em colmos e grãos.

Segundo EVANS et al. (1975) o período de fertilização até rápido acúmulo de matéria seca no grão ("lag phase"), pode variar de 12 para 20 dias em cultivares de milho tropical, em contraste com cereais de grãos pequenos, tais como trigo, que tem uma "lag phase" de menos de sete dias.

\subsubsection{Peso do grão}

Peso individual do grão é o produto da duração do período efetivo de enchimento de grão e a taxa de crescimento do grão. A interação desses dois componentes com a disponibilidade de assimilados, e seus efeitos combinados no rendimento de milho tropical carecem de maiores esclarecimentos. Variação no rendimento médio foi relatado para mudanças na taxa de acúmulo de matéria seca pelos grãos, mas não a duração do período efetivo de enchimento de grãos.

$O$ peso individual de grãos depende quase inteiramente de fatores que controlam a oferta de assimilados para enchimento de grãos (fonte) relativo ao número total de grãos e ao limite genético do crescimento individual de grão-dreno.

DUNCAN (1975) considerou rendimento de grãos de milho como um produto da quantidade de assimilados disponíveis para enchimento de grãos (fotossíntese e a mudança em reservas lábeis) multiplicada pela duração do período de enchimento de grãos. A capacidade individual do grão-dreno estabeleceu o limite superior do rendimento. 


\subsection{Cultivo de milho de "safrinha"}

O cultivo de milho de "safrinha" tem sido caracterizado por esforços isolados de técnicos e produtores. A partir da década de 1980, esse cultivo tem sido sinônimo de pioneirismo e determinação, muito embora ainda persistam, por deficiência de informações sobre cultivares e de administração, a idéia de alto risco e baixas produções.

O cultivo de milho de "safrinha" tem apresentado, entretanto, expansão em áreas diversas, sob diferentes circunstâncias. No Brasil Central esse cultivo se apresenta como promissor. Segundo WRIGHT et al. (1991) o sudeste dos Estados Unidos é reconhecidamente uma área deficiente na produção de grãos. Mrilho tropical oferece a opção de plantio após colhida alguma cultura tardia de primavera. Isto pode ajudar a oferta de grãos e reduzir o risco de produção, redistribuindo-o para mais de uma cultura. Milho tropical tem sido avaliado por vários anos para determinar o potencial de grãos quando plantado após culturas de grãos pequenos. Crescendo em um sistema de rotação com trigo seguido de milho apresenta-se como nova oportunidade de fazer uma cultura de grãos, caso algum desastre ocorra com a primeira.

\subsection{Somatório de Graus-dia (GD) acumulados no ciclo do milho}

O desenvolvimento vegetal é influenciado pela disponibilidade térmica, durante todo o seu ciclo. Cada genótipo ajusta-se a uma temperatura base, ou zero vital, abaixo da çual ele não se desenvolve. Para o milho, evidências experimentais tem apontado $10^{\circ} \mathrm{c}$ como temperatura base (GILMORE \& ROGERS, 1958; BERLATO et al., 1973), podendo variar com o genótipo e a fase de desenvolvimento da cultura (BERLATO \& SUTLI, 1976). 
Segundo VILLA NOVA et al. (1972) e MOTA (1975) a quantidade de energia exigida por uma cultura tem sido expressa em Graus-dia (GD), ou Unidades Térmicas de Desenvolvimento (UTD), Unidades de Calor, Soma de Temperatura, Exigência Térmica, Constante Térmica. Graus-dia é entendido como a medida da diferença entre a temperatura média diária e a temperatura mínima ou temperatura base, exigida por uma espécie.

Segundo CARDOSO \& MUNDSTOCK (1979), o método direto é o mais simples para o cálculo de unidades térmicas de desenvolvimento. Ele se baseia no somatório de temperaturas obtidas através da média entre a máxima e mínima diárias, com exceção dos valores abaixo de $0^{\circ} \mathrm{c}$ que não são computados. A crítica a esse método baseia-se no fato de que a constante térmica sofre variações segundo as localidades consideradas, pois tanto o crescimento como o desenvolvimento da maioria das plantas cultivadas começam com temperatura superior à temperatura de fusão do gelo. Para minimizar esse aspecto e encontrar a real eficiência da temperatura, subtrai-se da média diária a temperatura mínima da espécie (ASPIAZÚ \& SHAW, 1971; CROSS \& ZUBER, 1972; GILMORE \& ROGERS, 1958).

Em geral, é utilizado $10^{\circ} \mathrm{C}$ para o milho, emibora alguns trabalhos apresentem o valor de $4,4^{\circ} \mathrm{C}$ (ASPIAZÚ, 1971). Apesar dessa correção apresentar melhores resultados que o uso do método direto, ainda ocorrem variações na constante térmica para regiões distintas. MEDERSKI et al. (1973) e NEWMAN (1971), dentre outros, utilizaram uma temperatura-base superior e uma temperatura-base inferior, objetivando eliminar o efeito prejudicial das temperaturas extremas. GLMORE \& ROGERS (1958) e PLETT (1992) utilizaram para o milho, o seguinte método:

$\mathrm{GD}=\Sigma\left[\left\{\mathrm{Tmax}\left(\leq 30^{\circ} \mathrm{C}\right)+\mathrm{T} \min \left(210^{\circ} \mathrm{C}\right)\right\} / 2\right]-\mathrm{T}$ base $\left(=10^{\circ} \mathrm{C}\right)$. 


\subsection{Metodologias em análise de crescimento vegetal}

A análise matemática dos parâmetros morfofisiológicos de planta é feita por duas metodologias: clássica ou funcional.

A metodologia clássica permite uma estimativa de valores médios no intervalo entre duas amostragens. Esse método exige que as amostragens sejam simultâneas, para permitir a comparação entre cultivares e os diferentes tratamentos (PEREIRA \& MACHADO, 1987). E ainda, que a obtenção de determinados parâmetros requer algumas condições, como por exemplo, para o cálculo da taxa de assimilação líquida, a área foliar e a massa seca devem variar linearmente.

$\mathrm{Na}$ metodologia funcional, a utilização de modelos matemáticos empíricos aos dados primários de matéria seca e área foliar em função do tempo, minimiza os problemas apresentados pela metodologia tradicional. Modernamente, os índices e parâmetros morfofisiológicos são obtidos a partir de equações ou funções ajustadas. Dessa forma, os valores instantâneos e variação temporal dos diversos índices são obtidos através de funções e suas derivadas.

As vantagens e limitações do uso de fórmulas de integração e de modelos matemáticos para o cálculo de índices fisiológicos, a partir de dados de matéria seca (W) e área foliar (AF), estão relatados em CALBO et al. (1989b). O uso de modelos matemáticos derivados pode fornecer subsídios para melhor compreensão dos diferentes processos fisiológicos envolvidos na morfogênese da planta.

CALBO et al. (1989a) apresentaram funções para ajuste de curvas de crescimento no tempo, sendo que, a logística e a Gompertz são bastante utilizadas.

Uma alternativa ao uso de funções de crescimento é o de polinômios. Dados n pares de valores, polinômios de grau até $(n-1)$ podem ser ajustados ao seu conjunto. Em geral, quanto maior a variabilidade dos dados, menor é o grau do 
polinômio. Segundo PEREIRA \& MACHADO (1987), na prática, procura-se um polinômio de grau menor que (n-1) que descreva adequadamente a tendência dos dados.

Vários autores, dentre eles RICHARDS (1969) e PEREIRA \& MACHADO (1987) advertem para o emprego de funções, ajustadas demasiadamente, na estimativa dos índices fisiológicos. Invariavelmente, elas produzem resultados dificeis de serem explicados biologicamente. A função selecionada deve ser suficientemente complexa para descrever os dados originais, e suficientemente simples para permitir seu manuseio sem introduzir discrepâncias nas variáveis derivadas.

O ajuste de funções matemáticas aos dados de variações de matéria seca no tempo envolve critérios subjetivos. CALBO et al. (1989b) testaram várias funções e embora várias delas representem bem a matéria seca e a área foliar no tempo, os valores estimados de alguns parâmetros, especialmente a taxa de crescimento relativo e a taxa de assimilação líquida foram extremamente diferentes, de acordo com as funções matemáticas que foram ajustadas, resultando em curvas pouco confiáveis. Isto não se deve à variação experimental, mas a uma tendência introduzida diretamente pelas funções matemáticas empregadas para representar $\mathrm{W}$ e $\mathrm{AF}$ no tempo. Os autores sugerem que a técnica tradicional de análise de crescimento ainda deve seŕ utilizada em estudos fisiológicos do crescimento, por estar fundamentada em bases sólidas que permitem comparações estatísticas. 


\section{MATERIAL E MÉTODOS}

Os estudos foram realizados em Piracicaba, SP, no Campus da USP/ESALQ, no período de fevereiro a julho de 1992, sob condiçōes de campo.

As condições climáticas no período de realização do experimento são mostradas na Figura 1 e Anexo I (Dados obtidos no Posto Agrometeorológico do Departamento de Física e Meteorologia da ESALQ, USP. Coordenadas Geográficas: 22042'30" de latitude sul, 47038'00" de longitude oeste e 546 metros de altitude). A radiação global no período, variou de 42.651 a $45.894 \mathrm{cal}_{\mathrm{cm}} \mathrm{cm}^{-2}$, entre os tratamentos (considerando da semeadura até o máximo acúmulo de matéria seca dos grãos).

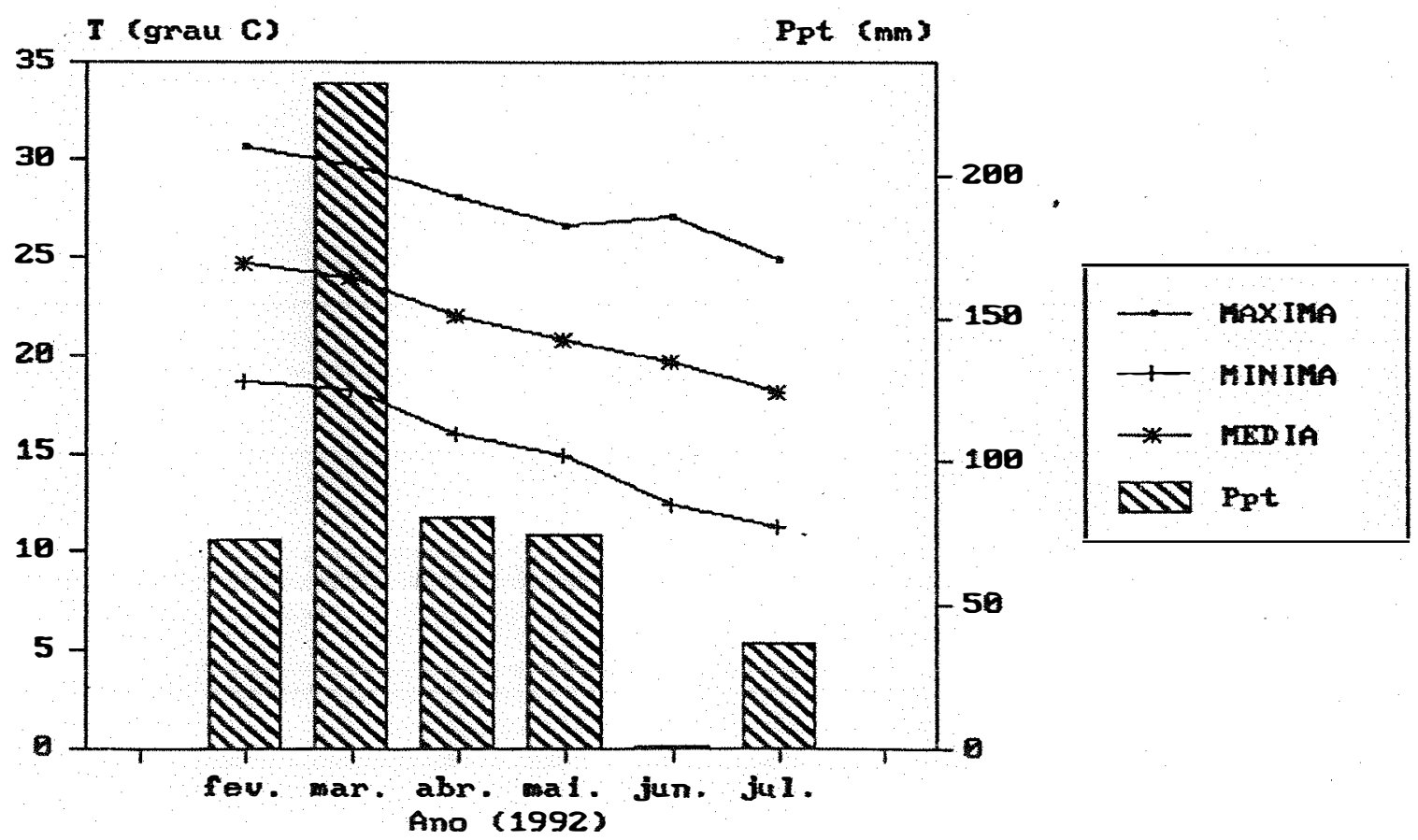

Figura 1 - Médias de temperatura do ar e precipitação mensal, de Fevereiro a Julho de 1992. Piracicaba, SP. 


\subsection{Caracterização dos cultivares utilizados}

Foram utilizados três cultivares comerciais de milho (Tabela 1), sendo representativos de diferentes ciclos de cultivo, quais sejam: Normal, Precoce e Superprecoce.

Tabela 1 - Características dos cultivares de milho de diferentes ciclos

\begin{tabular}{lll}
\hline Identificação(ciclo) & Nome Comercial & Tipo de Cultivar \\
\hline c1 (Normal) & BRASKALB XL 380 & Híbrido Triplo \\
c2 (Precoce) & EMBRAPA BR 201 & Híbrido Duplo \\
c3 (Superprecoce) & PIONEER P 3072 & Híbrido Simples modificado \\
\hline
\end{tabular}

\subsection{Tratamentos}

Os cultivares utilizados (c1, c2 e c3) foram cultivados em três densidades de população de plantas, quais sejam: $\mathrm{dl}=33,3$ mil plantas $/ \mathrm{ha}, \mathrm{d} 2=55,5 \mathrm{mil}$ plantas/ha e d3 $=77,7$ mil plantas/ha, totalizando nove tratamentos (cldl, cld2, cld3, $c 2 d 1, c 2 d 2, c 2 d 3, c 3 d 1, c 3 d 2, c 3 d 3)$.

\subsection{Delineamento experimental}

O experimento foi conduzido no delineamento de blocos casualizados, com parcelas subdivididas, com quatro repetições. As parcelas foram constituídas por um fatorial 32 , formado pelos fatores cultivar e densidade, cada um com três níveis (cultivar $=\mathrm{cl}, \mathrm{c} 2, \mathrm{c} 3$; densidade $=\mathrm{d} 1, \mathrm{~d} 2, \mathrm{~d} 3$ ).

A parcela experimental foi composta por cinco linhas de $16,0 \mathrm{~m}$ de comprimento, espaçadas $0,90 \mathrm{~m}$ entre si. As duas linhas extremas serviram como bordaduras. As amostragens periódicas de plantas, em número de dez, foram realizadas 
em três plantas representativas da fase da cultura na parcela e colhidas das três fileiras centrais, em intervalos de 14 dias. A primeira amostragem foi efetuada no $21^{\circ}$ dia após a semeadura (DAS) e coincidente com o desbaste de plântulas, para ajuste das densidades de plantas programadas nos tratamentos.

Em cada parcela foi reservada uma subparcela para determinação da produção final, constituída de $6,0 \mathrm{~m}$ de cada uma das três linhas centrais.

\subsection{Técnicas culturais}

As análises das propriedades fisicas e químicas do solo foram realizadas no Laboratório de Análise de Solo e Plantas, do Departamento de Ciência do Solo da ESALQ, USP. Os resultados da análise química foram: $\mathrm{pH} \mathrm{CaCl}=4,8, \mathrm{P}=36 \mathrm{ug} / \mathrm{cm}^{3}$; $\mathrm{K}=0,41 \mathrm{meq} / 100 \mathrm{~cm}^{3}$; Matéria Orgânica $=2,6 \%, \mathrm{SB}=7,8 \mathrm{meq} / 100 \mathrm{~cm}^{3}, \mathrm{~T}=14,2$ meq $/ 100 \mathrm{~cm}^{3}, \mathrm{~V}=55 \%, \mathrm{~m}=4 \%$, caracterizando o solo de média a alta fertilidade.

O solo é caracterizado por Terra Roxa estruturada eutrófica, A moderado, textura argilosa/muito argilosa (VIDAL TORRADO \& SPAROVEK, 1993).

O preparo do solo consistiu de uma aração e gradeação, na véspera da semeadura do experimento.

A adubação mineral, para todos os tratamentos, seguiu as dosagens descritas na Tabela 2 .

Tabela 2 - Adubação N, P, K utilizada para milho. Piracicaba, SP (Fevereiro/1992).

\begin{tabular}{lccc}
\hline EPOCA & \multicolumn{4}{c}{ Nutrientes $(\mathrm{kg} / \mathrm{ha})$} \\
\cline { 2 - 4 } & $\mathrm{N}$ & $\mathrm{P}_{2} \mathrm{O}_{5}$ & $\mathrm{~K}_{2} \mathrm{O}$ \\
\hline Plantio & 15 & 100 & 50 \\
$1^{\mathrm{s}}$ cobertura (35 DAS) & 40 & 0 & 25 \\
$2^{\mathrm{s}}$ cobertura (49 DAS) & 40 & 0 & 0 \\
\hline
\end{tabular}

DAS: Dias Após Semeadura 
As aplicações de adubos no plantio foram feitas manualmente nos sulcos de plantio, espaçados de $0,90 \mathrm{~m}$ entre si, abertos com sulcador tracionado por trator. As adubações de cobertura foram aplicadas manualmente, conforme Tabela 2.

A semeadura foi realizada manualmente, em 13/fevereiro/1992, dispondo-se de dez sementes por metro linear de sulco, espaçadas de 0,10m. Aos 21 dias após a semeadura (21 DAS) foi realizado o desbaste de plântulas, conforme as populações programadas nos tratamentos. Aos 28 DAS foi aplicado 0,8 litros de 2-4,D por hectare, com pulverizador de barra acoplado em trator.

\subsection{Determinações}

Durante o ciclo das plantas foram efetuadas avaliações para a caracterização das etapas vegetativa, reprodutiva e de formação dos grãos, assim como para a avaliação das espigas.

\subsubsection{Características morfológicas}

Foram determinadas altura da planta e o número de folhas por planta, para cada tratamento, com quatro repetições. Utilizou-se os dados médios de três plantas, por parcela.

Altura da planta: medida, em centímetro, do colo da planta (rente ao solo) até o ápice do limbo da primeira folha superior, para a fase jovem. E, após a emissão do pendão, a altura da planta foi determinada do colo até a lígula visível (colar de interseção da bainha e limbo foliar) da primeira folha superior.

Número de folhas por planta: contagem do número de folhas total e com lígula visível (limbo foliar totalmente expandido). 


\subsection{2. Área foliar}

Efetuou-se, em cada folha da planta, as medições do comprimento do limbo (C) e da maior largura (L). A área foliar (AF) foi estimada através da expressão (C $\times$ L x 0,75), proposta por MONTGCMERY (1911). O somatório das áreas foliares individuais da planta permitiram a obtenção da área foliar de cada planta. Utilizou-se, por tratamento e em cada época amostrada, a média de três plantas.

\subsubsection{Matéria seca da planta}

As coletas de plantas para a determinação da matéria seca foram realizadas em intervalos regulares de 14 dias, a partir do $21^{\circ}$ dia (inclusive), durante todo o ciclo da cultura. As plantas foram cortadas ao nível do solo, em cada parcela. Por dificuldades operacionais não foram utilizadas raízes. A seguir, nos estádios pertinentes, seus órgãos $\{$ (colmo+bainha, $c+b$; limbo foliar, f; pendão, pe; (espiga, e) $=$ (brácteas, br) + (sabugo, sa) + (grãos, gr) $\}$ foram separados e secados em estufa de circulação forçada, a uma temperatura de $70^{\circ} \mathrm{c}$, onde permaneceram até atingirem peso constante. Os dados coletados foram submetidos à análise de variância. Também foi testada a regressão ajustada aos dados de matéria seca total e de grãos.

\subsubsection{Produção por área}

Para determinar a produção por área, de grãos e da palhada, utilizou-se os dados das coletas periódicas. Deu-se preferência a esse procedimento, em relação aos dados da subparcela destinada à produção final, porque pode-se assim identificar o periodo de enchimento de grãos (via acúmulo de matéria seca nos grãos, por parcela), o que contribuiu para as análises realizadas. 
O rendimento de grãos apresentado, em $\mathrm{kg} / \mathrm{ha}$, foi corrigido para $13 \%$

de umidade.

Os componentes do rendimento foram avaliados, tomando-se cinco plantas por parcela, em quatro repetições.

\subsection{Análise estatística}

Os diferentes parâmetros foram submetidos à análise de variância pelo teste F. Diferenças de médias entre tratamentos foram comparadas pelo teste de Duncan, ao nivel de $5 \%$ de probabilidade.

\subsection{Obtenção de parâmetros fisiológicos}

fisiológicos:

Para efeito desse estudo, obteve-se os seguintes parâmetros

- Índice de área foliar (IAF)

- Produtividade biológica (PB)

- Taxa de crescimento da cultura (TCC)

- Taxa de crescimento do grão (TCG)

\subsubsection{Indice de área foliar (IAF)}

É a relação de área foliar total da planta, considerando-se apenas uma face do limbo foliar, por unidade de área de terreno disponível para a planta $\left(L^{2} \cdot L^{-2}\right)$.

$$
(\mathrm{IAF}=\mathrm{AF} / \mathrm{S}),\left(\mathrm{cm}^{2} \text { área foliar } / \mathrm{cm}^{2} \text { área terreno }\right)
$$

Nesse estudo foi definida uma equação polinomial quadrática ajustada aos dados, média de três plantas, em quatro repetições:

$$
\left(\operatorname{IAF}=a+b t+c t^{2}\right)
$$




\subsubsection{Produtividade biológica (PB)}

É a massa acumulada da matéria seca total da planta, por unidade de área do terreno (W.L ${ }^{-2}$ ).

$$
(\mathrm{PB}=\mathrm{a}+\mathrm{bt})
$$

\subsubsection{Taxa de crescimento da cultura (TCC)}

É a massa acumulada da matéria seca total, por unidade de terreno e tempo (W.L-2. $\left.\mathrm{T}^{-1}\right)$.

$(\mathrm{TCC}=\mathrm{dPB} / \mathrm{dt})=(\mathrm{l} / \mathrm{S}) \cdot(\mathrm{dW} / \mathrm{dt}),\left(\mathrm{g}\right.$ matéria seca $/ \mathrm{m}^{2}$ área terreno.dia1).

Nesse estudo foi definida uma função logística ajustada aos dados de matéria seca total, média de três plantas, em quatro repetições:

$$
W=a /\left(1+b e^{-k t}\right)
$$

\subsubsection{Taxa de crescimento do grão (TCG)}

É a massa acumulada da matéria seca do grão, por unidade de terreno e tempo (wgr. $\left.\mathrm{L}^{-2} \cdot \mathrm{T}^{-1}\right)$. Foi definida uma função logística à semelhança de TCC.

Unidades:

$$
\begin{aligned}
& \mathrm{t} \quad=\text { Tempo (DAS) } \\
& \mathrm{W}=\text { Massa seca total da planta (média, } \mathrm{g} / \mathrm{m}^{2} \text { ) } \\
& \mathrm{wgr}=\text { Massa seca total de grãos (médià, } \mathrm{g} / \mathrm{m}^{2} \text { ) } \\
& \mathrm{A}=\text { Área foliar }\left(\mathrm{cm}^{2}\right) \\
& \mathrm{S}=\text { Área do terreno disponivel à planta }\left(\mathrm{m}^{2}\right)
\end{aligned}
$$


Para cada parâmetro calculado, obteve-se uma equação que se ajustasse adequadamente aos dados e a respectiva curva da variável, em função do tempo.

Para melhor visualização das comparações das curvas de crescimento entre os tratamentos, as figuras foram elaboradas na mesma escala.

\subsection{Obtenção de índices de colheita, de partição e de esforço reprodutivo}

\subsubsection{Indice de colheita (IC)}

O IC (ou índice de safra) em uma cultura madura é a fração da produção econômica (grão) relativa à fitomassa total colhida. O IC reflete a partição da matéria seca entre grão e a haste, folhas (e raízes).

IC é calculado pela fórmula:

IC $=\operatorname{wgr}\left(\phi_{f}\right.$, ou colheita $) / W\left(\phi_{f}\right.$, ou colheita $)$

onde,

$$
\begin{aligned}
& \text { wgr = matéria seca de grãos } \\
& \phi_{\mathrm{f}}=\text { ponto de maturidade fisiológica de grãos (ou na colheita) } \\
& \mathrm{W}=\text { fitomassa seca total da planta }
\end{aligned}
$$

\subsubsection{Estimativa do Indice de Colheita Genético (ICG)}

A comparação entre os tratamentos (cultivar $x$ densidade) foi feita, também baseando-se na estimativa do ICG.

A inclinação de uma curva superior, representando o rendimento de grãos $\mathrm{x}$ matéria seca, por tratamento, passando pela origem, aproxima-se do ICG. Isto porque o mais alto rendimento de grãos em relação à matéria seca total da planta representa o menor estresse e/ou plantas bem adaptadas, e a passagem pela origem é necessária para satisfazer a definição de Índice de Colheita (IC). 


\subsection{2. Índice de partição (IP)}

O IP (ou índice de distribuição) é a taxa de rendimento de grãos para a fitomassa total produzida após o florescimento.

IP pode ser calculado pela fórmula:

$$
\mathrm{IP}=\mathrm{wgT}\left(\phi_{\mathrm{f}}-\phi_{\mathrm{i}}\right) / \mathrm{W}\left(\phi_{\mathrm{f}}-\phi_{\mathrm{i}}\right)
$$

onde,

$$
\begin{aligned}
& \text { wgr }=\text { matéria seca de grãos } \\
& \left(\phi_{\mathrm{f}}-\phi_{\mathrm{j}}\right)=\text { período de enchimento de grãos } \\
& \cdot \mathrm{W}=\text { fitomassa seca total da planta }
\end{aligned}
$$

\subsection{3. Índice de esforço reprodutivo (IER)}

O IER é a proporção da energia total que o organismo destina à reprodução, num intervalo de tempo específico e biologicamente significativo. O IER é dado pela razão entre energia destinada aos órgãos reprodutivos e a energia total da planta.

IER pode ser calculado pela fórmula:

$$
\operatorname{IER}=\Sigma\{\mathrm{w}(\mathrm{pe}+\mathrm{br}+\mathrm{sa}+\mathrm{gr})\} / \mathrm{W}
$$

onde,

$$
\begin{aligned}
& \Sigma\{\mathrm{w}(\mathrm{pe}+\mathrm{br}+\mathrm{sa}+\mathrm{gr})\}=\text { é o somatório dos pesos individuais da matéria } \\
& \text { seca dos órgãos reprodutivos da planta } \\
& \mathrm{W}=\text { fitomassa seca total da planta }
\end{aligned}
$$




\subsubsection{Interrelações do IC, IP e IER e suas relações com rendimento de grãos}

IC, $\mathbb{P}$ e IER são índices que refletem a interação genótipo $x$ ambiente nas produções biológica e econômica primárias. São todos baseados na produção relativa de matéria seca em órgãos reprodutivos e/ou de interesse econômico da planta.

3.9. Obtenção de Graus-dia (GD) por subperíodo de desenvolvimento do milho: vegetativo e enchimento de grãos.

As temperaturas, para a computação de GD foram obtidas dos dados coletados no Posto Agrometeorológico de Departamento de Física e Meteorologia da ESALQ, USP, durante a realização do experimento.

Os períodos estudados foram: da semeadura ao início do período de enchimento de grãos, e período de enchimento de grãos (do início de enchimento de grãos ao ponto de maturidade fisiológica).

O método direto foi empregado para o cálculo de GD, utilizando-se a

fórmula:

$$
\mathrm{GD}=\Sigma\{(\mathrm{T} \min +\mathrm{T} \max ) / 2\}-\mathrm{T} \text { base }
$$

onde,

$\mathrm{T} \min =10$ para $\mathrm{T} \min <10^{\circ} \mathrm{c}$;

$\mathrm{T} \max =30$ para $\mathrm{T} \max >30^{\circ} \mathrm{c}$;

$\mathrm{T}$ base $=10^{\circ} \mathrm{C}$. 


\section{RESULTADOS E DISCUSSÃO}

\subsection{Matéria seca total da planta e de suas partes}

A matéria seca total da planta compreende o somatório da matéria seca das folhas, colmotbainha, pendão, brácteas, sabugos e grãos. Por dificuldades operacionais não foram utilizadas raizes. A Figura $2(a, b, c)$ mostra as varią̧ões do acúmulo de matéria seca total, por tratamento, em função do tempo.

Os coeficientes das equações que melhor se ajustaram aos dados para matéria seca total e matéria seca dos grãos encontram-se nos Anexos II e III.

O crescimento de uma planta, expresso pelo acúmulo de matéria seca, geralmente apresenta um comportamento sigmoidal. No periodo inicial, o crescimento é lento. Segue-se uma fase de rápido aumento do tamanho e, finalmente, um decréscimo na acumulação (MAGALHÃES, 1979). Tal comportamento é bastante evidente quando se considera apenas o acúmulo de matéria seca das folhas e/ou dos colmos+bainhas.

MACHADO et al. (1982) observaram também que a planta de milho continuou acumulando matéria seca até a maturidade fisiológica. $\mathrm{O}$ aumento ocorrido na matéria seca dos grãos coincidiu com o decréscimo verificado nos colmostbainhas e folhas, fazendo com que a matéria seca total da planta continuasse crescendo. Curvas similares para sorgo foram obtidas por BENINCASA (1977). 


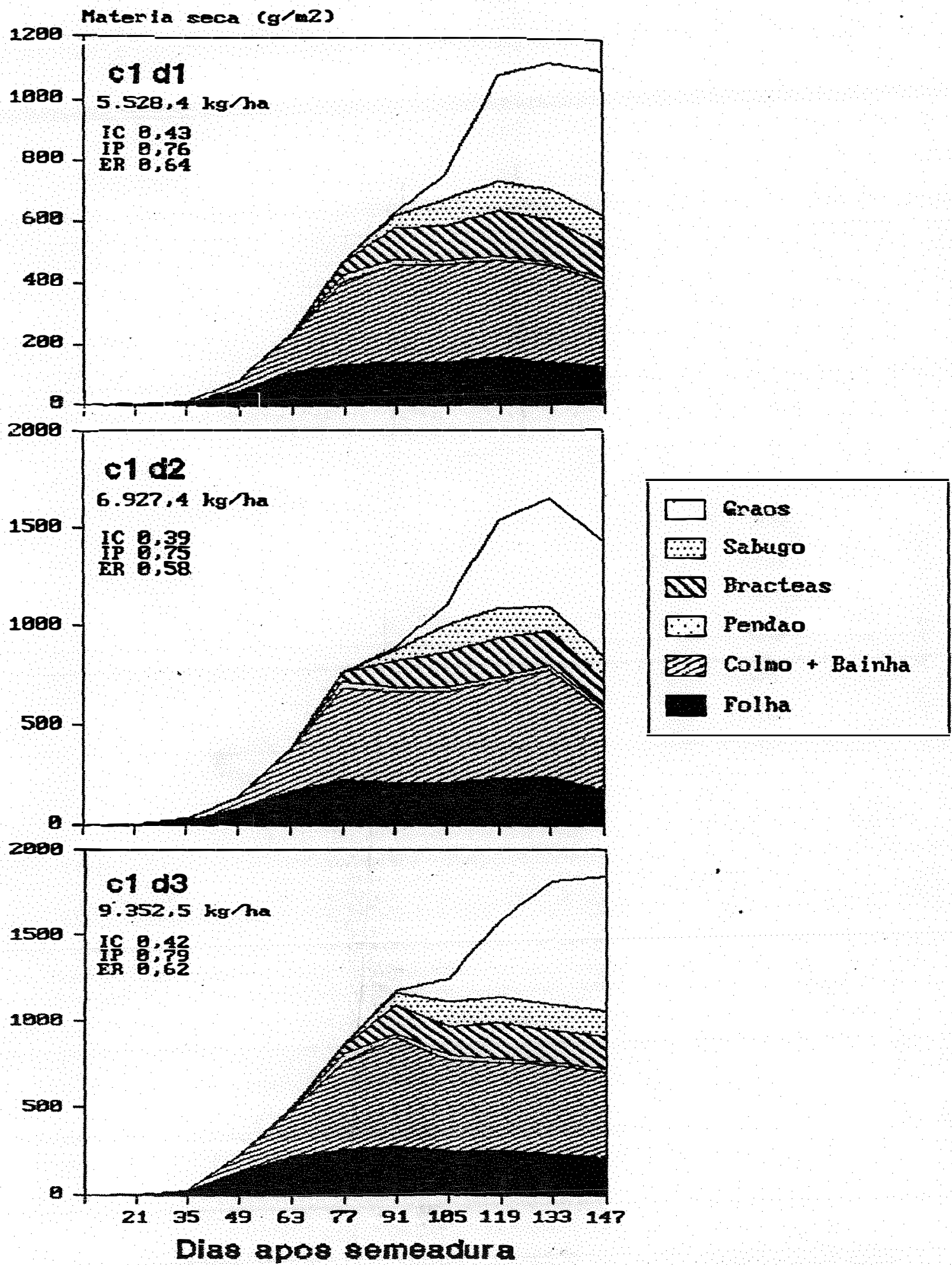

Figura 2a - Acúmulo diferencial de matéria seca em cultivares de milho de diferentes ciclos $(\mathrm{cl}=$ Normal), em três densidades de cultivo de safrinha $(\mathrm{dl}=33,3$ mil, d2 = 55,5 mil, d3 = 77,7 mil plantas/ha). Piracicaba, SP. 1992. 


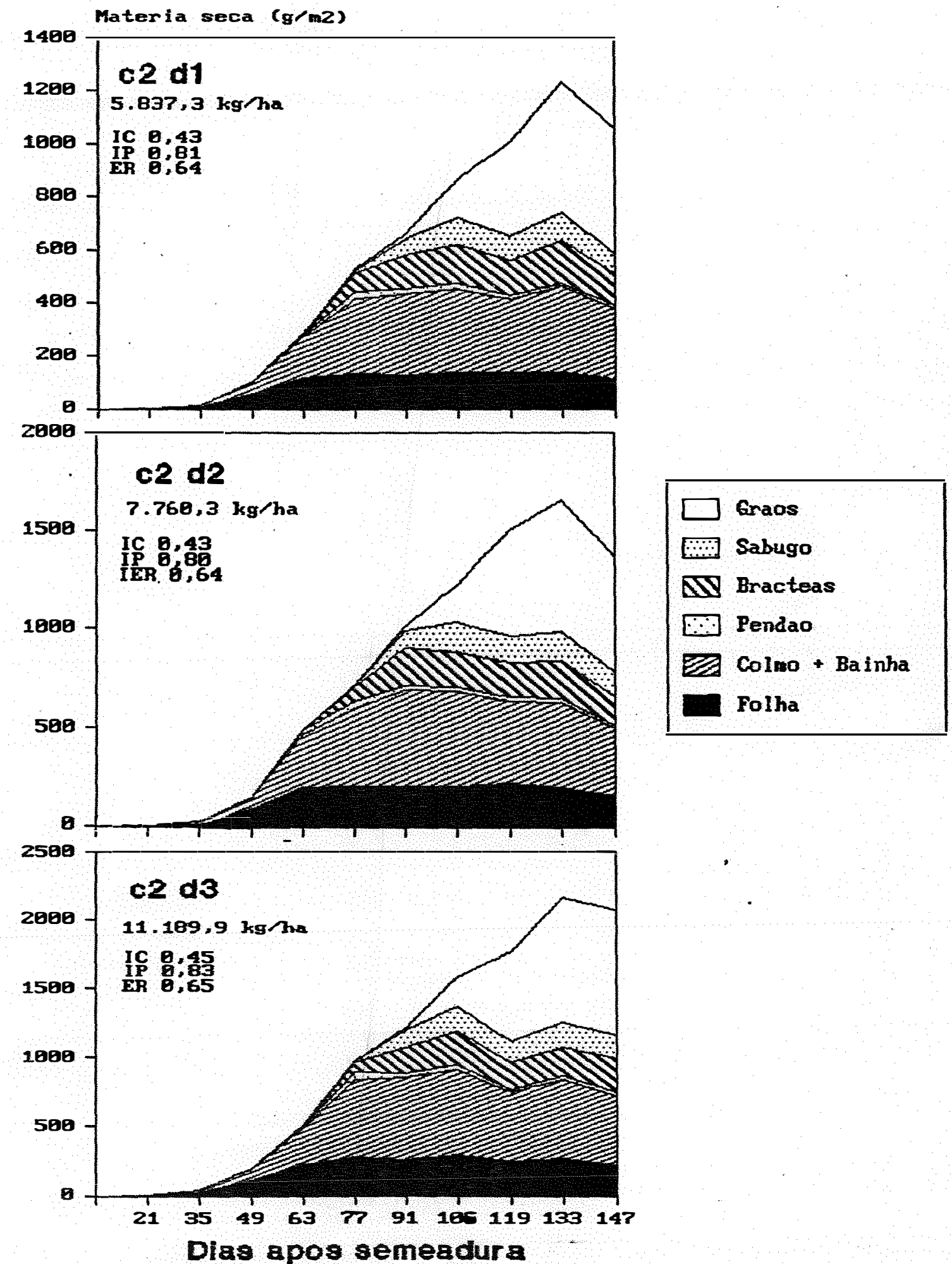

Figura $2 \mathrm{~b}$ - Acúmulo diferencial de matéria seca em cultivares de milho de diferentes ciclos $(\mathrm{c} 2=$ Precoce), em três densidades de cultivo de safrinha $(\mathrm{d} 1=33,3$ mil, d2 = 55,5 mil, d3 =77,7 mil plantas/ha). Piracicaba, SP. 1992. 


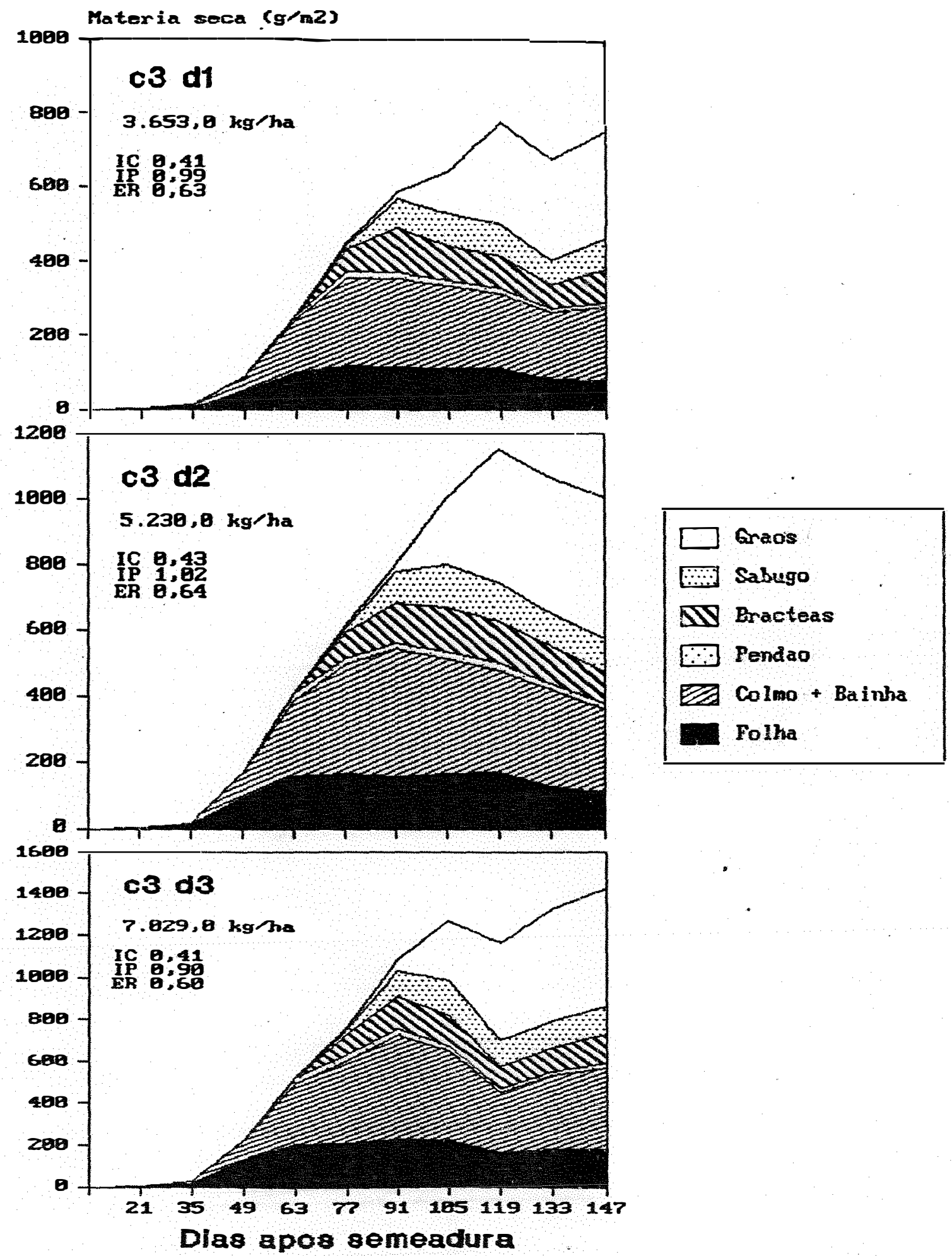

Figura 2c - Acúmulo diferencial de matéria seca em cultivares de milho de diferentes ciclos ( $c 3=$ Superprecoce), em três densidades de cultivo de safrinha $(\mathrm{d} l=$ 33,3 mil, d2 = 55,5 mil, d3 =77,7 mil plantas/ha). Piracicaba, SP. 1992. 
A distribuição relativa sazonal de matéria seca em cultivares de milho de diferentes ciclos, em três densidades de plantio, é apresentada, por cultivar, na Figura $3(a, b, c)$. Variação na densidade de cultivo resultou em alterações morfológicas e fisiológicas nas plantas, sem praticamente modificar a distribuição relativa de matéria seca entre os órgãos da planta. Observou-se uma compensação por área de terreno, resultando em maiores acúmulos de matéria seca total e de grãos, nas maiores densidades de cultivo, para os três cultivares.

Para fins desse estudo deu-se maior ênfase no período de enchimento de grãos (PEG), razão pela qual ao se determinar a duração desse período procurou-se adotar um critério para definir seu início e final. Adotou-se como marco inicial do PEG as coletas realizadas aos $77 \mathrm{DAS}$ porque foram verificados, em todos os tratamentos, em quatro repetições, acúmulo inicial de matéria seca nos grãos.

$O$ final do período do PEG foi definido, por tratamento, em quatro repetições, como a data de coleta em que se obteve o máximo de acúmulo de matéria seca nos grãos (denominado ponto de maturidade fisiológica, PMF).

Os dados da Tabela 3 mostram que, aos 77 DAS, os percentuais desse acúmulo foram mínimos, em relação à matéria seca total dos grãos. Portanto, nesse estudo, o PEG entre 77 DAS e PMF, compreendendo todos os tratamentos, representa mais que $98 \%$ do enchimento de grãos. 
Tabela 3 - Matéria seca da planta total (MST) e dos grãos (MSG), relativa aos periodos de máximo acúmulo (máx.), no ponto de maturidade fisiológica (PMF), e aos 77 dias após a semeadura ( 77 DAS) de cultivares de milho de diferentes ciclos, em três densidades de cultivo de safrinha. Piracicaba, SP. 1992.

\begin{tabular}{|c|c|c|c|c|c|c|c|c|}
\hline \multirow{3}{*}{ Trat } & \multicolumn{4}{|c|}{ MST } & \multicolumn{4}{|c|}{ MSG } \\
\hline & \multicolumn{2}{|c|}{ máx. } & \multirow{2}{*}{$\frac{\text { PMF }}{\%}$} & \multirow{2}{*}{$\frac{77 \mathrm{DAS}}{\%}$} & \multicolumn{2}{|c|}{ máx=PMF } & \multirow{2}{*}{$\begin{array}{c}77 \text { DAS } \\
\mathrm{g} / \mathrm{m}^{2}\end{array}$} & \multirow[b]{2}{*}{$\%$} \\
\hline & DAS & $\mathrm{g} / \mathrm{m}^{2}$ & & & $\overline{\mathrm{DAS}}$ & $\mathrm{g} / \mathrm{m}^{2}$ & & \\
\hline cldl & 133 & 1110,613 & 97,7 & 42,1 & 147 & 475,738 & 2,295 & 0,48 \\
\hline cld2 & 133 & 1653,581 & 86,4 & 46,2 & 147 & 586,650 & 2,011 & 0,34 \\
\hline $\mathrm{cld} 3$ & 147 & 1843,886 & 100,0 & 47,3 & 147 & 780,976 & 3,242 & 0,41 \\
\hline Média & 137,7 & 1536,027 & 94,7 & 45,2 & 147 & 614,455 & 2,516 & 0,41 \\
\hline $\mathrm{c} 2 \mathrm{dl}$ & 133 & 1234,192 & 100,0 & 42,9 & 133 & 494,705 & 5,450 & 1,10 \\
\hline $\mathrm{c} 2 \mathrm{~d} 2$ & 133 & 1647,965 & 100,0 & 34,3 & 133 & 671,671 & 5,111 & 0,76 \\
\hline $\mathrm{c} 2 \mathrm{~d} 3$ & 133 & 2159,209 & 100,0 & 45,1 & 133 & 910,882 & 5,420 & 0,59 \\
\hline Média & 133 & 1680,455 & 100,0 & 40,8 & 133 & 692,419 & 5,327 & 0,82 \\
\hline $\mathrm{c} 3 \mathrm{dl}$ & 119 & 776,145 & 97,1 & 58,2 & 147 & 292,585 & 4,853 & 1,66 \\
\hline c3d2 & 119 & 1150,804 & 87,1 & 53,2 & 147 & 425,595 & 7,770 & 1,82 \\
\hline c3d3 & 147 & 1422,534 & 100,0 & 53,8 & 147 & 557,411 & 11,728 & 2,10 \\
\hline Média & 128,3 & 1116,494 & 94,7 & 55,1 & 147 & 421,864 & 8,117 & 1,86 \\
\hline
\end{tabular}

Os valores máximos de matéria seca total $\left(1.111 ; 1.654 ; 1.844 \mathrm{~g} / \mathrm{m}^{2}\right.$, para $\mathrm{cld} 1, \mathrm{cld} 2 \mathrm{e} \mathrm{cld} 3$, respectivamente, foram atingidos no período entre duas semanas antes até à maturação, de $\left(1.234 ; 1.648,2.159 \mathrm{~g} / \mathrm{m}^{2}\right.$, para c2 d1, c2d2 e c2d3, respectivamente, atingidos na maturação; e, de $\left(776 ; 1.151 ; 1.423 \mathrm{~g} / \mathrm{m}^{2}\right.$, para c3d1, c3d2 e c3d3, respectivamente, atingidos no período compreendido entre quatro semanas antes até à maturação (Tabela 3).

A análise de variância dos dados de matéria seca total apresenta diferença significativa, a nível de $1 \%$ de probabilidade para o teste de $F$, para os fatores cultivar e densidade; entretanto, não foi significativo para a interação cultivar $\mathrm{x}$ densidade. 


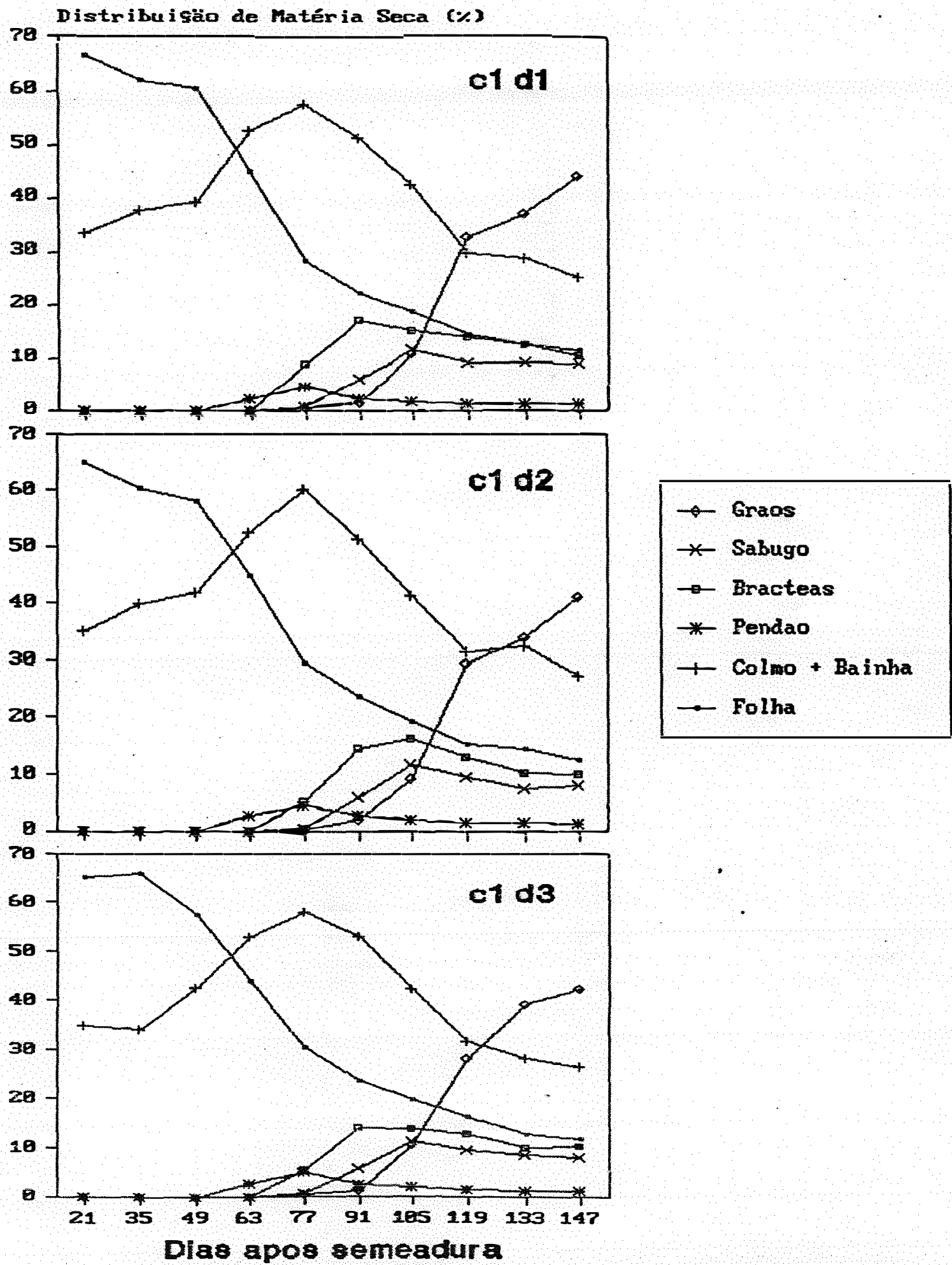

Figura 3a - Distribuiçäo relativa sazonal de matéria seca $\left(\mathrm{g} / \mathrm{m}^{2}\right)$ em cultivares de milho de diferentes ciclos $(\mathrm{cl}=$ Normal), em três densidades de cultivo de safininha ( $\mathrm{dl}$ $=33,3 \mathrm{mil}, \mathrm{d} 2=55,5 \mathrm{mil}, \mathrm{d} 3=77,7 \mathrm{mil}$ plantas/ha). Piracicaba, SP. 1992. 

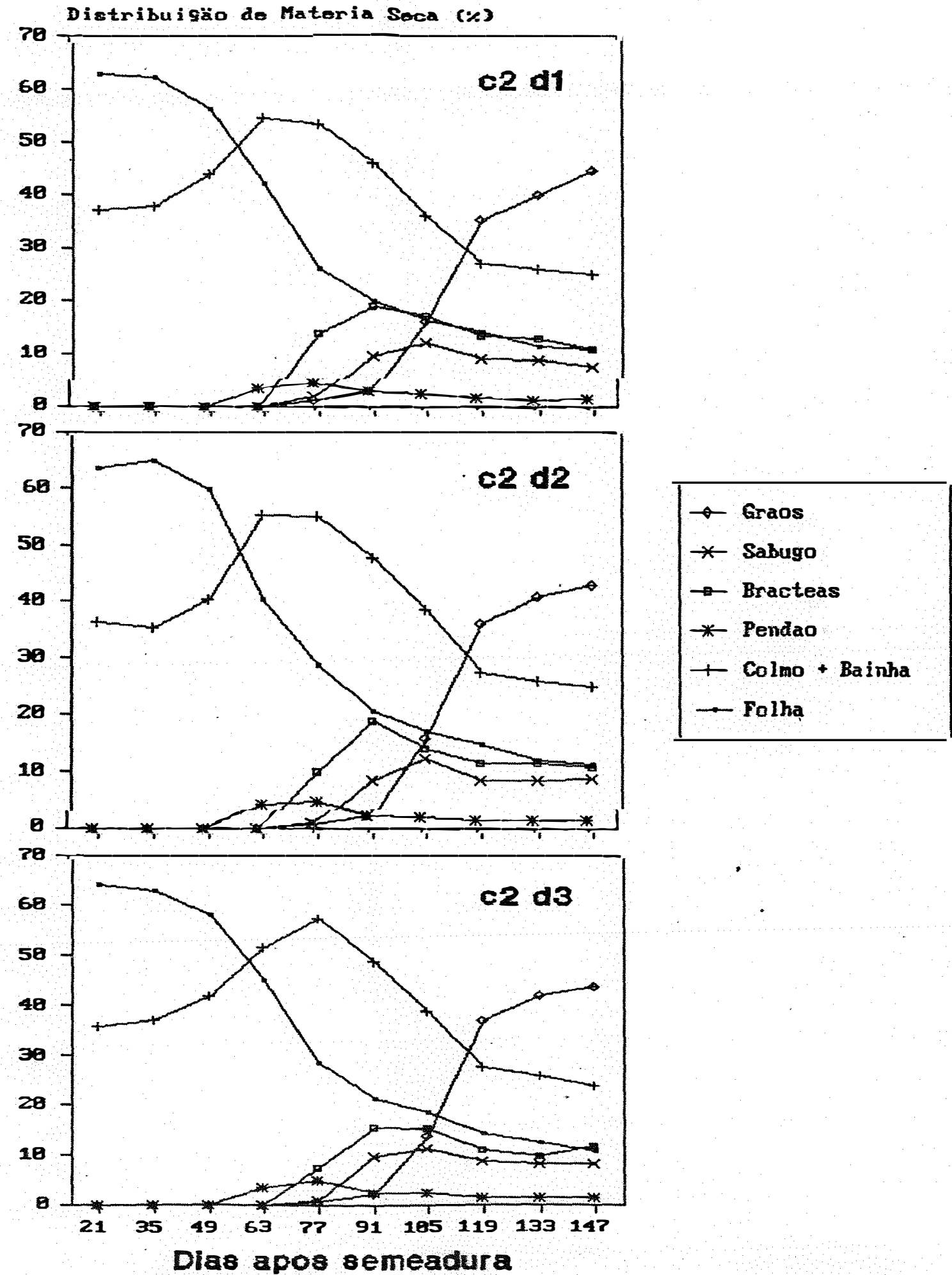

Figura 3b - Distribuiçäo relativa sazonal de matéria seca $\left(\mathrm{g} / \mathrm{m}^{2}\right)$ em cultivares de milho de diferentes ciclos (c2 = Precoce), em três densidades de cultivo de safrinha (d) $=33,3 \mathrm{mil}, \mathrm{d} 2=55,5 \mathrm{mil}, \mathrm{d} 3=77,7 \mathrm{mil}$ plantas $/ \mathrm{ha}$ ). Piracicaba, SP. 1992. 

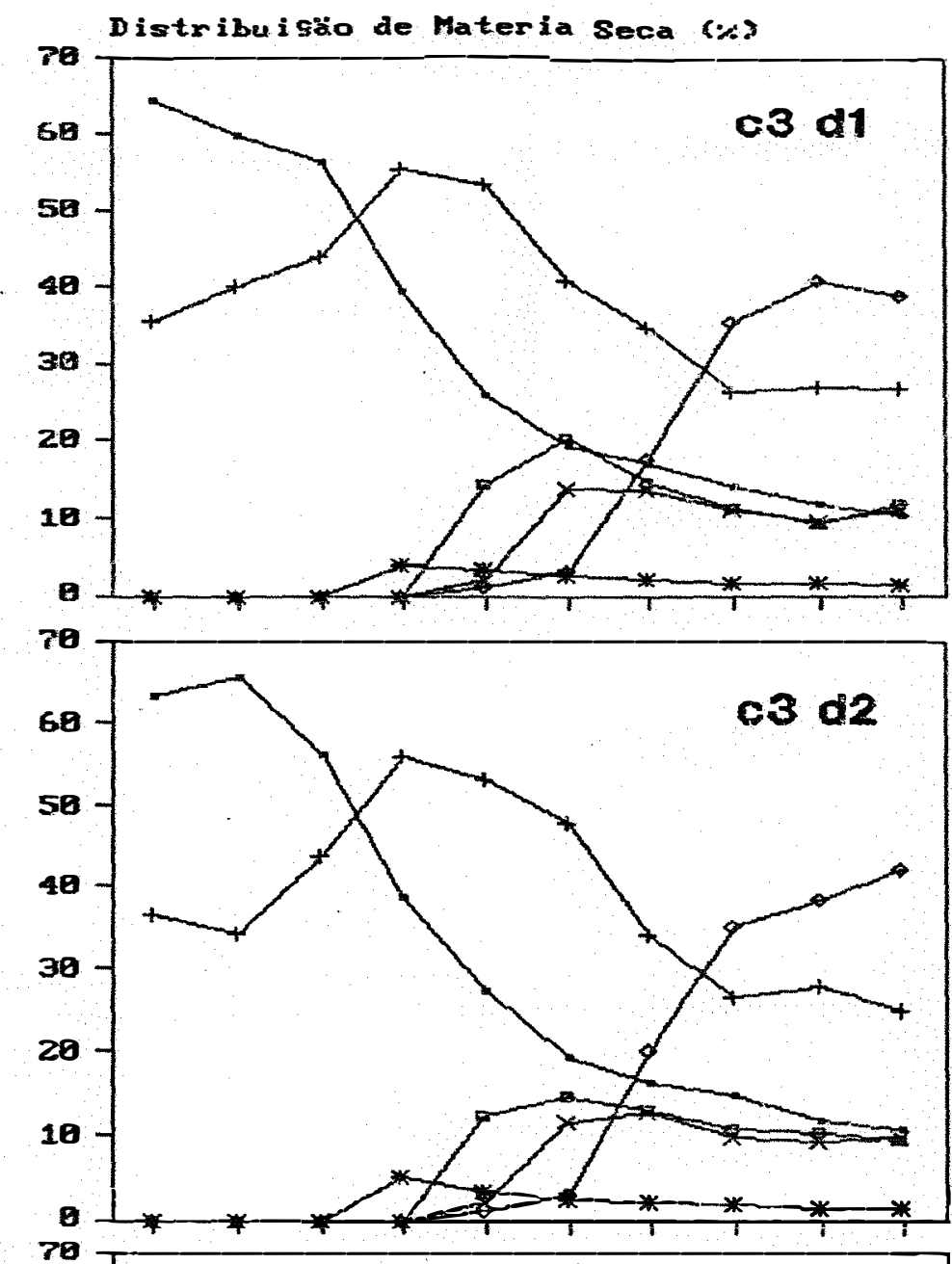

$$
\begin{aligned}
& \text { - Grans } \\
& * \text { Sabugo } \\
& - \text { Bracteas } \\
& * \text { Pendao } \\
& -+ \text { Colmo - Bainha } \\
& \rightarrow-\text { Folha }
\end{aligned}
$$

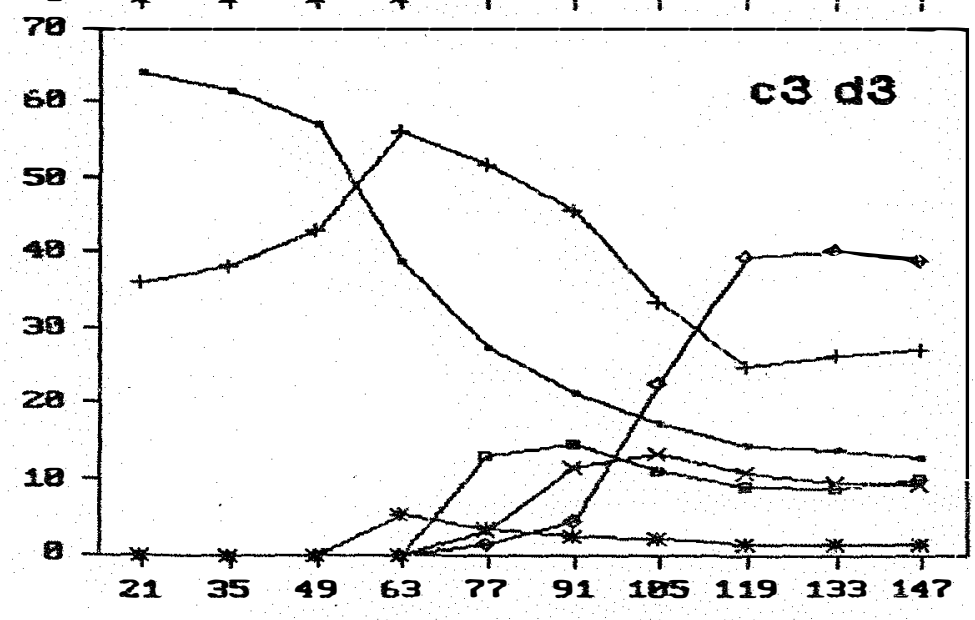

\section{Dias apos semeadura}

Figura 3c - Distribuiçäo relativa sazonal de matéria seca $\left(\mathrm{g} / \mathrm{m}^{2}\right)$ em cultivares de milho de diferentes ciclos (c3 = Superprecoce), em três densidades de cultivo de safrinha $(\mathrm{dl}=33,3 \mathrm{mil}, \mathrm{d} 2=55,5 \mathrm{mil}, \mathrm{d} 3=77,7 \mathrm{mil}$ plantas $/$ ha). Piracicaba, SP. 1992. 
A Tabela 4 mostra, por tratamento, durante o ciclo, a contribuição percentual das folhas, em relação à matéria seca máxima de folhas.

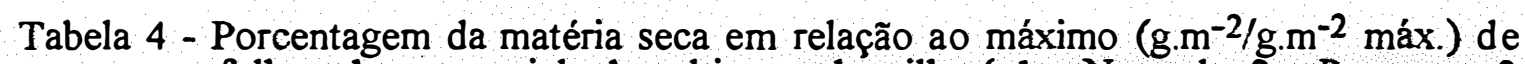
folhas, durante o ciclo de cultivares de milho ( $1=$ Normal, $c 2=$ Precoce, $c 3$

= Superprecoce), em três densidades de cultivo de safrinha (d1 = 33,3 mil, d2 $=55,5 \mathrm{mil}, \mathrm{d} 3=77,7 \mathrm{mil}$ plantas $/$ ha). Piracicaba, SP. 1992.

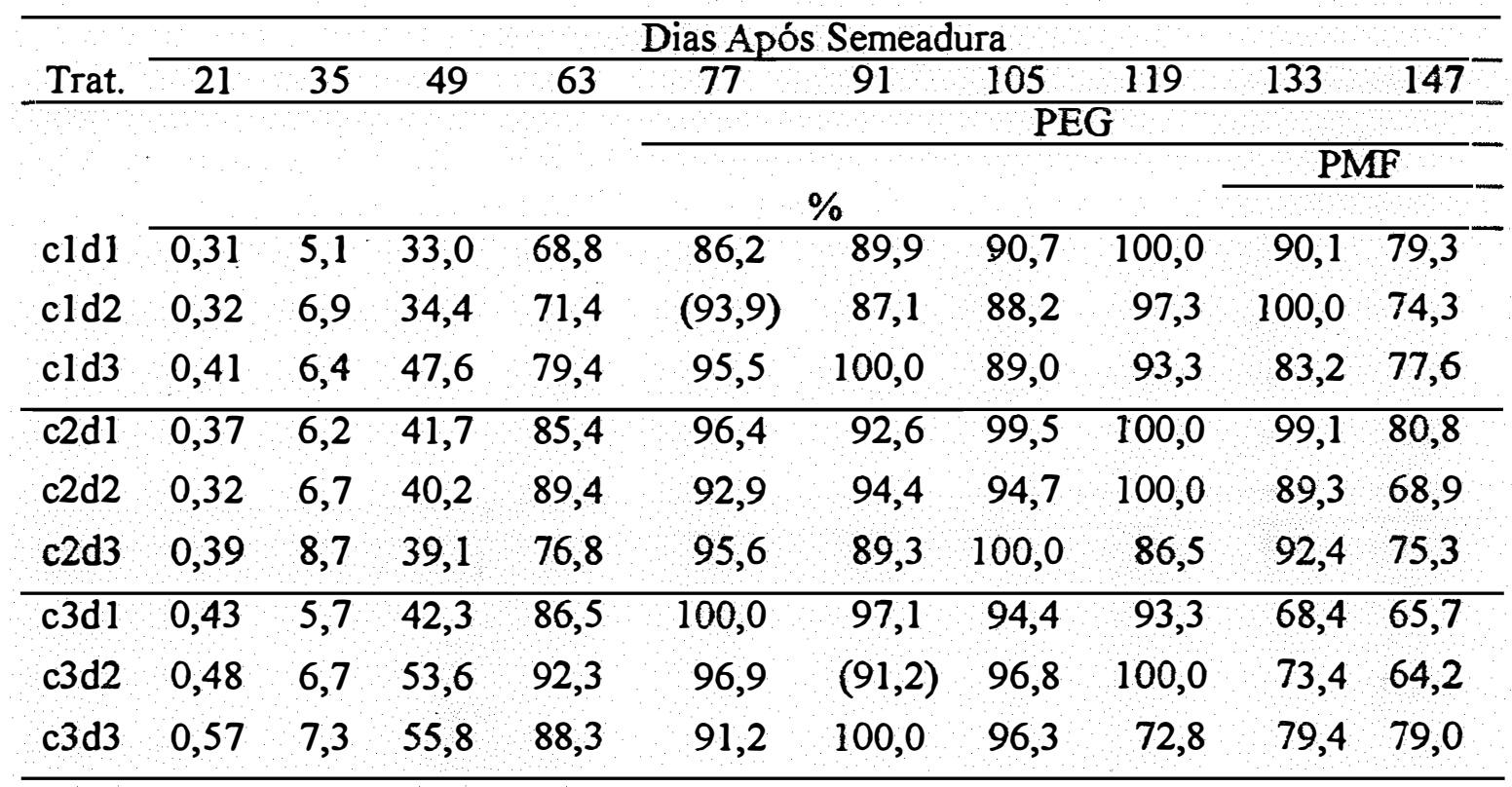

PEG: Período de enchimento de grãos

PMF: Ponto de maturidade fisiológica

A matéria seca das folhas (MSF) diferiu entre os três cultivares, nas três densidades de cultivo, aos 77 DAS, verificando-se diferenças maiores a partir desse estágio até o final do ciclo (Figura 2-a, b, c).

Essa característica, MSF, atingiu seu valor má imo, próximo do PMF para o cultivar normal (c1), próximo do início do período de enchimento de grãos (aos 77 DAS) para o cultivar Superprecoce (c3) e no período intermediário, para o cultivar Precoce (c2). 
Sendo a fotossintese o processo responsável pelo fornecimento da energia necessária ao crescimento e desenvolvimento da planta, esperava-se que, inicialmente a planta utilizasse a maior parte da energia disponivel na elaboração do órgão captador da radiação solar. No entanto, a maior parte de material assimilado até 77 DAS encontrava-se nos tecidos dos colmos. Em parte, isto se deveu ao fato de que a matéria seca dos colmos compreendeu também a matéria seca das bainhas foliares.

Em função da senescência das folhas inferiores, houve um decréscimo nas mesmas, para os três cultivares, até a maturação das plantas. Por pertencerem a tipos de plantas diferentes, e pela manutenção de estandes diferentes para cada cultivar, provavelmente resultou em crescimento vegetativo (e reprodutivo) distintos.

A mesma tendência dessas curvas foi verificada para o acúmulo de matéria seca dos colmos+bainhas (Figura 2 - a, b, c), para os diferentes cultivares, sendo que as diferenças entre o acúmulo desses foram mais evidentes do que as ocorridas no acúmulo das folhas.

\subsection{Variações de matéria seca}

O acúmulo de matéria seca total foi maior no cultivar Normal (c1), menor no cultivar Superprecoce (c3), e intermediário no cultivar Precoce (c2), (Tabela 3).

HANWAY \& RUSSELL (1969) obtiveram resultados similares. Concluiram que o maior acúmulo de matéria seca nos materiais tardios deve-se ao fato de possuirem maior ciclo, já que os índices de crescimento foram semelhantes.

BUREN et al. (1974) estudaram o parâmetro "eficiência do rendimento", com base no rendimento de grãos de milho por unidade de área foliar. Esse parâmetro se associou com pequeno tamanho de pendão e mais curto intervalo 
antese-florescimento feminino (IAE, intervalo antese espigamento; ou, "ASI, anthesis-tosilking interval"). Foi, entretanto, mais altamente associado com alto rendimento de grãos em alta densidade de plantas em híbridos de milho temperado. Descoberta similar foi relatada por TANAKA \& YAMAGUCHI (1972).

\section{GOLDSWORTHY \& COLEGROVE (1974) e GOLDSWORTHY et} al. (1974) encontraram que cultivares de milho tropical acumulam mais matéria seca nas partes vegetativas da planta que em partes reprodutivas após antese, e rendeu menos que cultivares de milho temperado. Concluiram que tamanho do dreno limitou o rendimento de grãos em genótipos de milho tropical.

Limitada capacidade de dreno em cultivares de milho tropical é atribuído pela competição entre partes vegetativas da planta e a espiga.

\section{3. Área foliar verde total}

Os valores estimados da área foliar total (média por planta), para os tratamentos, encontram-se na Tabela 5.

Tabela 5 - Valores estimados de área foliar total verde, (média por planta, $\mathrm{cm}^{2}$ ) em cultivares de milho de diferentes ciclos $(\mathrm{c} 1=$ Normal, $\mathrm{c} 2=$ Precoce, $\mathrm{c} 3=$ Superprecoce), em três densidades de cultivo de safrinha ( $\mathrm{d} 1=33,3 \mathrm{mil}$, $\mathrm{d} 2=55,5 \mathrm{mil}, \mathrm{d} 3=77,7$ mil plantas/ha). Piracicaba, SP. 1992.

\begin{tabular}{lrrrrrrrrrr}
\hline Trat. & \multicolumn{1}{c}{} & \multicolumn{10}{c}{ Dias Após Semeadura } \\
& 21 & 35 & 49 & 63 & 77 & 91 & 105 & 119 & 133 & 147 \\
\hline c1d1 & 70 & 836 & 3581 & 6316 & 6849 & 6990 & 6443 & 4940 & 2451 & 210 \\
c1d2 & 64 & 1049 & 3808 & 6392 & 7339 & 6836 & 5994 & 5260 & 3043 & 88 \\
c1d3 & 72 & 773 & 4183 & 5936 & 6739 & 6867 & 5406 & 3948 & 1331 & 149 \\
\hline c2d1 & 86 & 1018 & 4269 & 7275 & 6899 & 6823 & 6456 & 3809 & 842 & 171 \\
c2d2 & 76 & 988 & 4155 & 6766 & 6784 & 6385 & 5435 & 3607 & 367 & 0 \\
c2d3 & 79 & 1183 & 3855 & 6170 & 6647 & 6034 & 5808 & 2029 & 545 & 0 \\
\hline c3d1 & 72 & 748 & 3808 & 6013 & 6203 & 5738 & 4087 & 1154 & 79 & 0 \\
c3d2 & 71 & 747 & 4097 & 5649 & 5476 & 5276 & 3931 & 2102 & 87 & 0 \\
c3d3 & 82 & 828 & 4166 & 5375 & 5103 & 5441 & 3551 & 1323 & 16 & 0 \\
\hline
\end{tabular}


Os coeficientes das equações polinomiais quadráticas ajustadas aos dados observados de área foliar, com os respectivos coeficientes de determinação estão apresentados no Anexo IV. Para todos os tratamentos, a equação que se ajustou adequadamente aos dados de área foliar foi o polinômio de $2^{\circ}$ grau, com $R^{2}$ variando de 0,82 a 0,96 .

Observando-se os dados de área foliar (Tabela 5), nota-se que os cultivares, nas três densidades, apresentaram comportamentos semelhantes. A área foliar cresceu até um determinado estádio, atingiu um valor máximo próximo do início do período de enchimento de grãos (øi); e, a partir daí, em consequência da senescência das folhas inferiores, decresceu até o final do ciclo da planta (maturação). O processo de senescência no cultivar Superprecoce, que se iniciou após o florescimento (ou início do período de enchimento de grãos) foi mais acelerado. Essa característica contribuiu para o menor acúmulo de matéria seca total e do grão, e consequentemente, para os menores rendimentos do cultivar, nas três densidades de cultivo. Aliado a isto, o cultivar c3 produziu menor área foliar e apresentou menor ciclo de desenvolvimento. Produziu menos matéria seca total que os outros cultivares, em todas as fases de seu ciclo.

A Figura $4(a, b, c)$ mostra a relação entre IAF' e acúmulo de matéria seca total e nos grãos, em diferentes cultivares de milho. Como o comportamento de IAF, no tempo, reflete a área foliar dos diferentes cultivares, observa-se que as curvas que descrevem IAF apresentam essa mesma tendência.

Resultados semelhantes foram encontrados por diversos autores, em culturas diferentes, como para sorgo (BENINCASA, 1977), soja (SIVAKUMAR \& SHAW, 1978), milho (SILVA et al., 1974). 

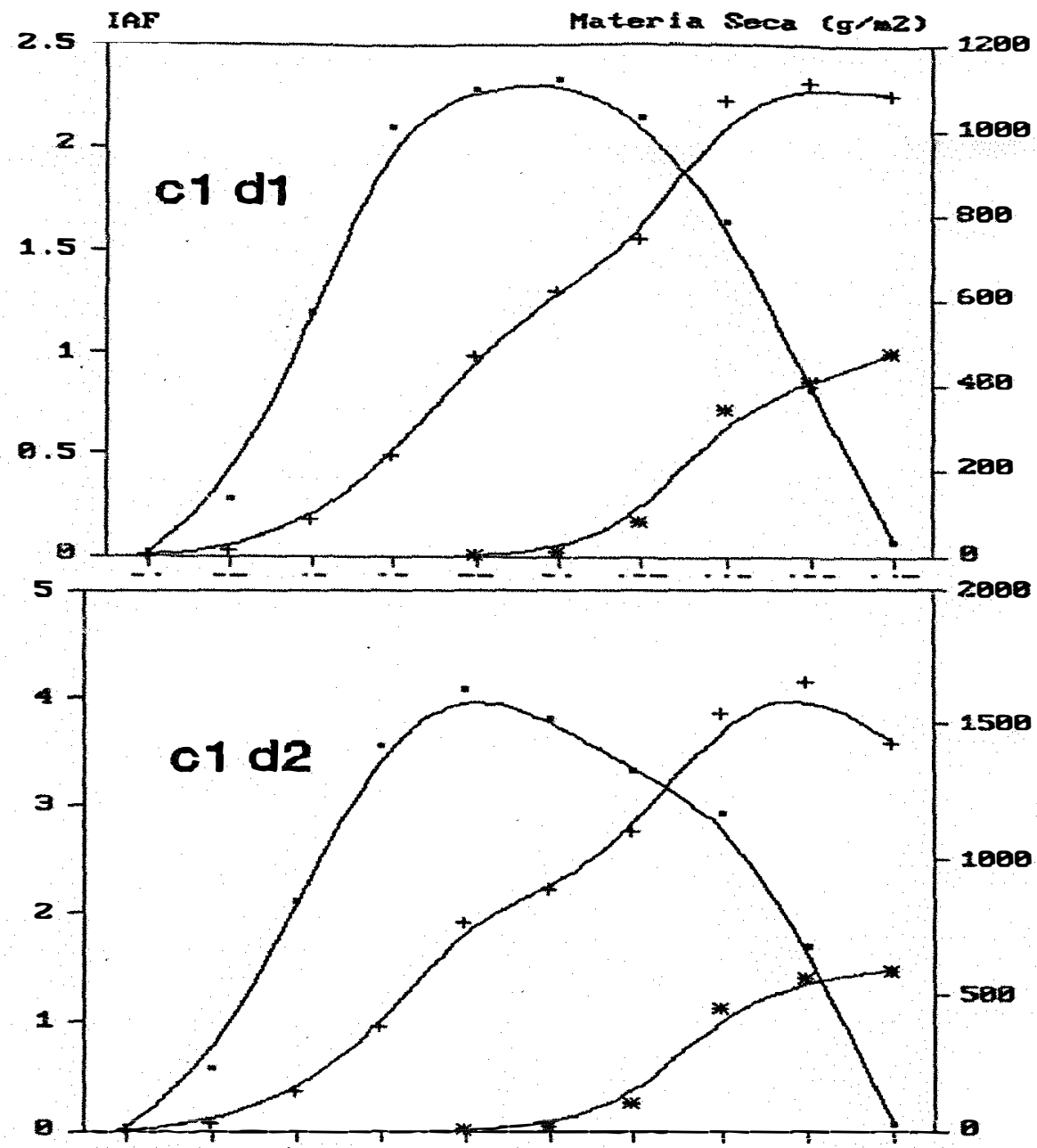

1580

6

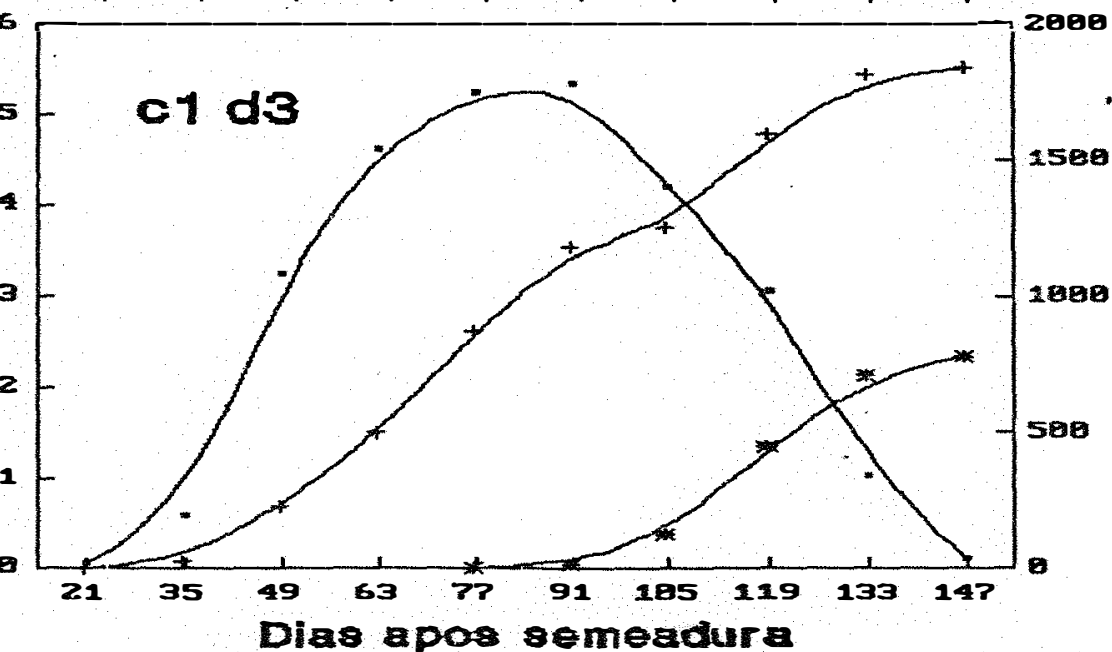

Figura 4a - Relação entre Índice de Área Foliar (IAF) e acúmulo de matéria seca total (MST) e de grãos (MSG), de cultivares de milho de diferentes ciclos (cl = Normal), em três densidades de cultivo de safrinha ( $\mathrm{dl}=33,3 \mathrm{mil}, \mathrm{d} 2=55,5$ mil, d3 = 77,7 mil plantas/ha). Piracicaba, SP. 1992. 

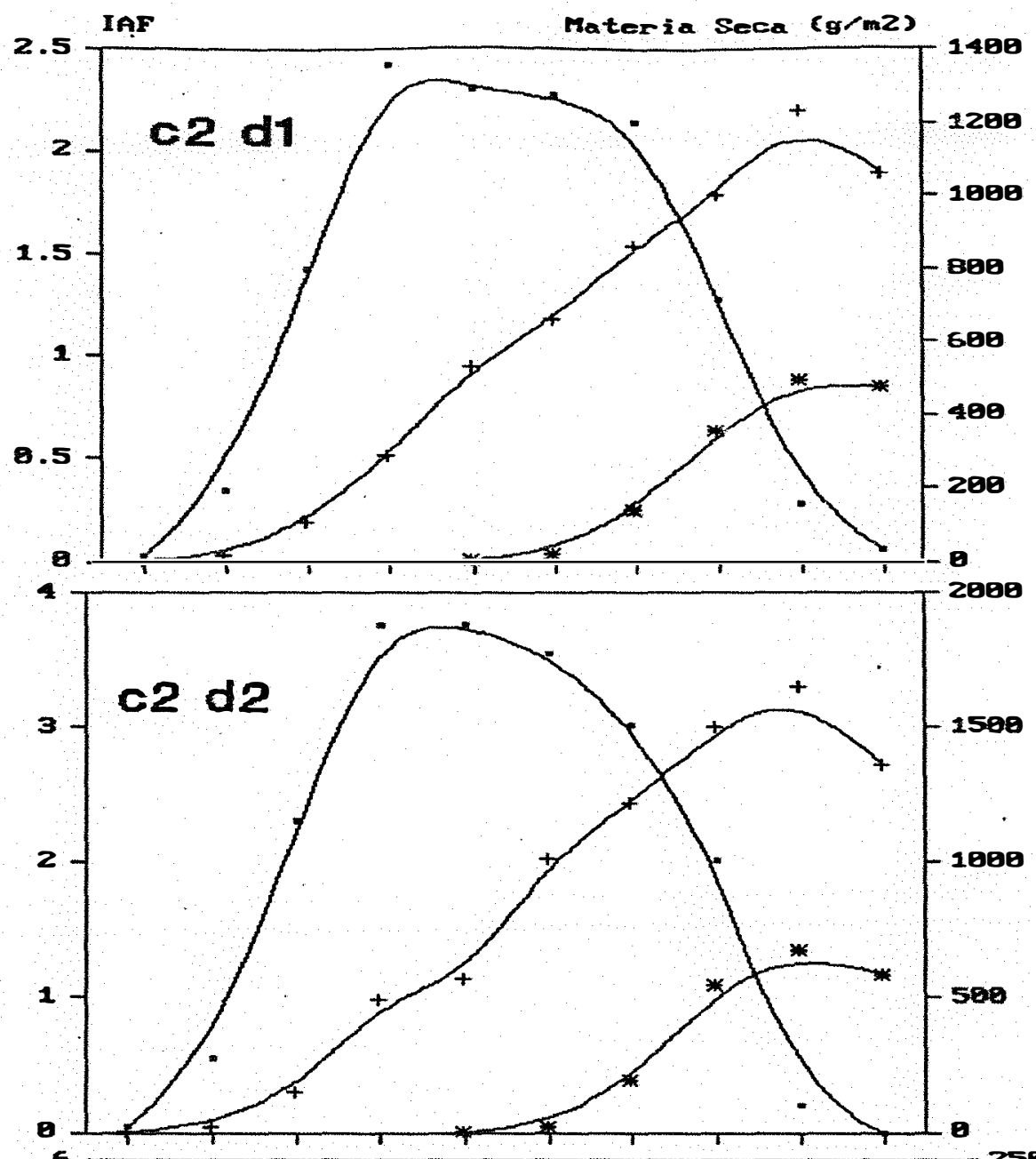

2808

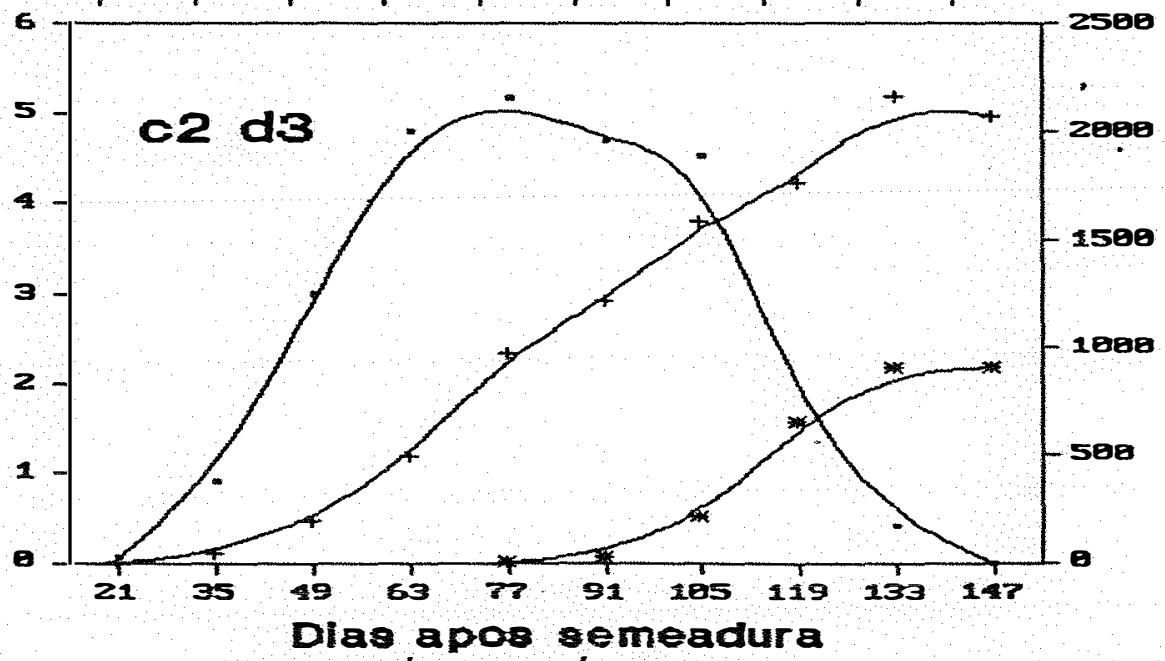

Figura $4 b$ - Relação entre Índice de Área Foliar (IAF) e acúmulo de matéria seca total (MST) e de grãos (MSG), de cultivares de milho de diferentes ciclos (c2 = Precoce), em três densidades de cultivo de safrinha ( $\mathrm{dl}=33,3 \mathrm{mil}, \mathrm{d} 2=55,5$ mil, d3 = 77,7 mil plantas/ha). Piracicaba, SP. 1992. 


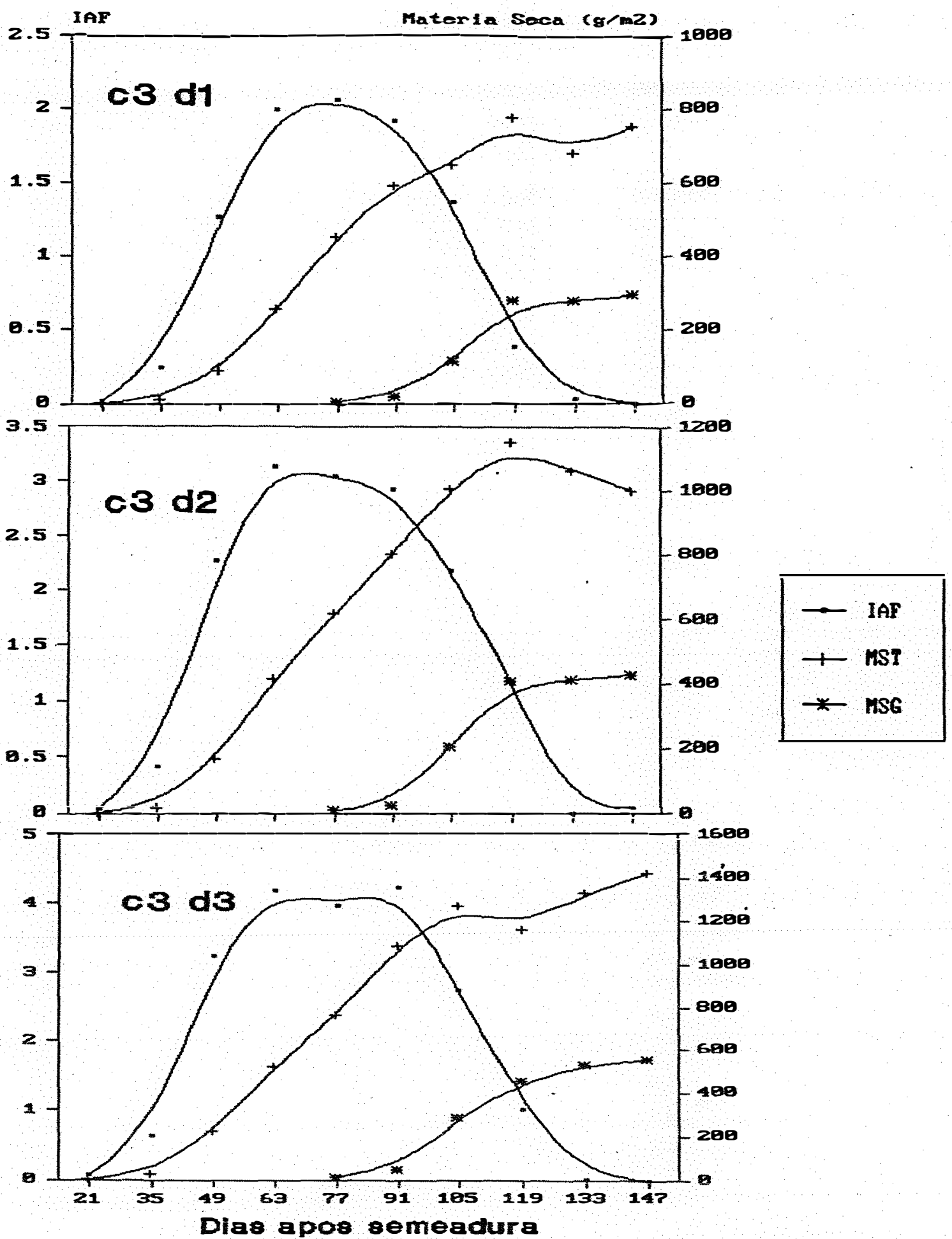

Figura 4c - Relação entre Índice de Área Foliar (IAF) e acúmulo de matéria seca total (MST) e de grãos (MSG), de cultivares de milho de diferentes ciclos ( $c 3=$ Superprecoce), em três densidades de cultivo de safiinha ( $\mathrm{d} 1=33,3 \mathrm{mil}, \mathrm{d} 2=$ 55,5 mil, d3 = 77,7 mil plantas/ha). Piracicaba, SP. 1992. 
HOYT \& BRADFIELD (1962) observaram que a taxa de crescimento é constante até o índice de área foliar igual a 2,7, passando então a apresentar acréscimos cada vez menores até IAF 4,0. Após esse IAF, passa a decrescer. Mueller, citado por BUNTING \& DRENNAN (1966), concluiu que o IAF ótimo para o crescimento foi 5.

\subsection{Rendimento de grãos e seus componentes}

O rendimento de grãos e seus componentes são apresentados na Tabela

6. Os rendimentos de grãos variaram entre os cultivares e entre as densidades, por cultivar. Rendimento de grãos foram significativamente superiores nas maiores densidades de cultivo, para os três cultivares avaliados.

Tabela 6 - Rendimento de grãos ( $\mathrm{kg} / \mathrm{ha}$, a $13 \%$ umidade), e componentes do rendimento, de cultivares de milho de diferentes ciclos $(\mathrm{cl}=$ Normal, $\mathrm{c} 2=$ Precoce, $\mathrm{c} 3=$ Superprecoce), em três densidades de cultivo de safrinha $(\mathrm{d} 1=33,3 \mathrm{mil}, \mathrm{d} 2=$ 55,5 mil, d3 = 77,7 mil plantas/ha). Piracicaba, SP. 1992.

\begin{tabular}{|c|c|c|c|c|c|c|c|}
\hline \multirow[t]{2}{*}{ Trat } & \multirow{2}{*}{$\begin{array}{l}\text { Rend. Grãos* } \\
\text { (kg/ha) }\end{array}$} & \multicolumn{6}{|c|}{ Componentes do rendimento $* *$} \\
\hline & & $\mathrm{CE}$ & $\mathrm{DE}$ & $\mathrm{NF} / \mathrm{E}$ & $\mathrm{QG} / \mathrm{F} / \mathrm{E}$ & QTG/E & $\mathrm{NG} / \mathrm{m}^{2} / \mathrm{T}$ \\
\hline \multicolumn{8}{|c|}{ c1, cultivar Normal } \\
\hline dl & 5528 ef & $16,9 a$ & $3,2 \mathrm{ab}$ & $13,2 \mathrm{abc}$ & $39,7 a$ & 522,2 ef & $1741 \mathrm{c}$ \\
\hline d2 & 6927 cde & $15,5 \mathrm{~b}$ & $3,1 b$ & $12,1 \mathrm{~d}$ & $36,7 \mathrm{abc}$ & 442,9 cde & $2460 \mathrm{~b}$ \\
\hline d3 & $9353 \mathrm{~b}$ & $14,7 \mathrm{bc}$ & $4,0 \mathrm{ab}$ & $12,5 \mathrm{~cd}$ & $33,7 \mathrm{~cd}$ & $419,5 \mathrm{~b}$ & $3262 a$ \\
\hline \multicolumn{8}{|c|}{ c2, cultivar Precoce } \\
\hline dl & $5837 \mathrm{def}$ & $16,0 \mathrm{ab}$ & $4,7 a$ & $13,2 \mathrm{abc}$ & $38,5 \mathrm{ab}$ & 505,2 def & $1684 \mathrm{c}$ \\
\hline d2 & $7760 \mathrm{c}$ & $16,0 \mathrm{ab}$ & $4,7 a$ & $13,1 \mathrm{bc}$ & $35,7 \mathrm{bcd}$ & $467,6 \mathrm{c}$ & $2597 \mathrm{~b}$ \\
\hline d3 & $11190 \mathrm{a}$ & $14,9 \mathrm{bc}$ & $4,5 \mathrm{ab}$ & $12,0 \mathrm{~d}$ & $35,9 \mathrm{bcd}$ & $428,9 a$ & $3335 a$ \\
\hline \multicolumn{8}{|c|}{ c3, cultivar Superprecoce } \\
\hline d1 & $3653 \mathrm{~g}$ & $13,8 \mathrm{~cd}$ & $4,4 \mathrm{ab}$ & $14,0 \mathrm{a}$ & $32,4 \mathrm{de}$ & 451,5 & $1505 \mathrm{c}$ \\
\hline d2 & $5230 \mathrm{f}$ & $13,2 \mathrm{~d}$ & $4,5 \mathrm{ab}$ & $13,9 \mathrm{ab}$ & $29,6 \mathrm{e}$ & $411,8 \mathrm{f}$ & $2286 \mathrm{~b}$ \\
\hline d3 & $7029 \mathrm{~cd}$ & $13,0 \mathrm{~d}$ & $4,4 a b$ & $13,9 \mathrm{ab}$ & 29,0 e & $405,2 \mathrm{~cd}$ & $3151 \mathrm{a}$ \\
\hline $\mathrm{cv} \%$ & 13,4 & 5,58 & 22,6 & 3,97 & 6,66 & 7,57 & 8,7 \\
\hline
\end{tabular}

$\mathrm{Na}$ coluna, médias seguidas da mesma letra não diferem entre si, a $5 \%$ de probabilidade, pelo teste de Duncan.

* (Rend Grãos, $\mathrm{kg} / \mathrm{ha}$, a $13 \%$ de umidade).

** Média de 5 espigas, por Tratamento.

(CE, comprimento da espiga, cm; DE, diâmetro da espiga, $\mathrm{cm}$; NF/E, número de fileiras por espiga; QG/F/E, quantidade de grãos por fileira por espiga; QTG/E, quantidade total de grãos por espiga; $\mathrm{NG} / \mathrm{m}^{2} / \mathrm{T}$, número de grãos por metro quadrado de terreno por tratamento (cultivar $\mathrm{x}$ densidade). 
O maior rendimento de grãos foi obtido com o cultivar c2 (média de $11.190 \mathrm{~kg} / \mathrm{ha}$ ). O cultivar normal, cl, produziu $9.353 \mathrm{~kg} / \mathrm{ha}$, e o cultivar Superprecoce, c3, produziu $7.029 \mathrm{~kg} / \mathrm{ha}$.

Esses rendimentos de grãos foram obtidos na maior densidade $(\mathrm{d} 3=$ 77,7 mil plantas/ha), pelos três cultivares analisados. Para as três cultivares, os menores rendimentos de grãos se verificaram na densidade menor ( $d 3=33,3$ mil plantas/ha).

Pelo teste de $\mathrm{F}$, a análise de variância dos dados apresentou significância para cultivar e densidade, para a variável rendimento de grãos.

A superioridade do cultivar precoce, c2, na produção de grãos, foi verificada nas três densidades de cultivo. O cultivar Superprecoce, c3, produziu menos grãos, e o cultivar Normal, cl, produziu intermediariamente. Os rendimentos foram crescentes e significativos com o aumento de densidades de cultivo, para os três cultivares.

No Anexo V são apresentados os coeficientes de correlações entre as variáveis QTG/E (quantidade total de grãos por espiga), NG/m²/T (número de grãos por metro quadrado de terreno, por tratamento) e rendimento de grãos $\left(\mathrm{g} / \mathrm{m}^{2}\right.$, a $13 \%$ de umidade).

Rendimento de grãos apresentou correlações positivas altas com o componente número de grãos $/ \mathrm{m}^{2}$ de terreno. Essas duas variáveis apresentaram correlações crescentes $(0,733,0,896$ e 0,918$)$ para os cultivares Normal, Precoce e Superprecoce, respectivamente. Número de grãos $/ \mathrm{m}^{2}$ variou entre densidades de cultivo, assumindo valores significativamente maiores, nas maiores densidades. 
Rendimento de grãos apresentou correlações negativas altas com o componente quantidade total de grãos/espiga, para os cultivares Normal e Precoce. Quantidade total de grãos/espiga variou significativamente entre cultivar e entre densidade.

\subsection{Avaliação do Índice de Colheita (IC)}

O IC, determinado pela relação entre matéria seca dos grãos e a matéria seca total da planta variou de 0,39 a 0,45 (Figura 5) e Tabela 8 .

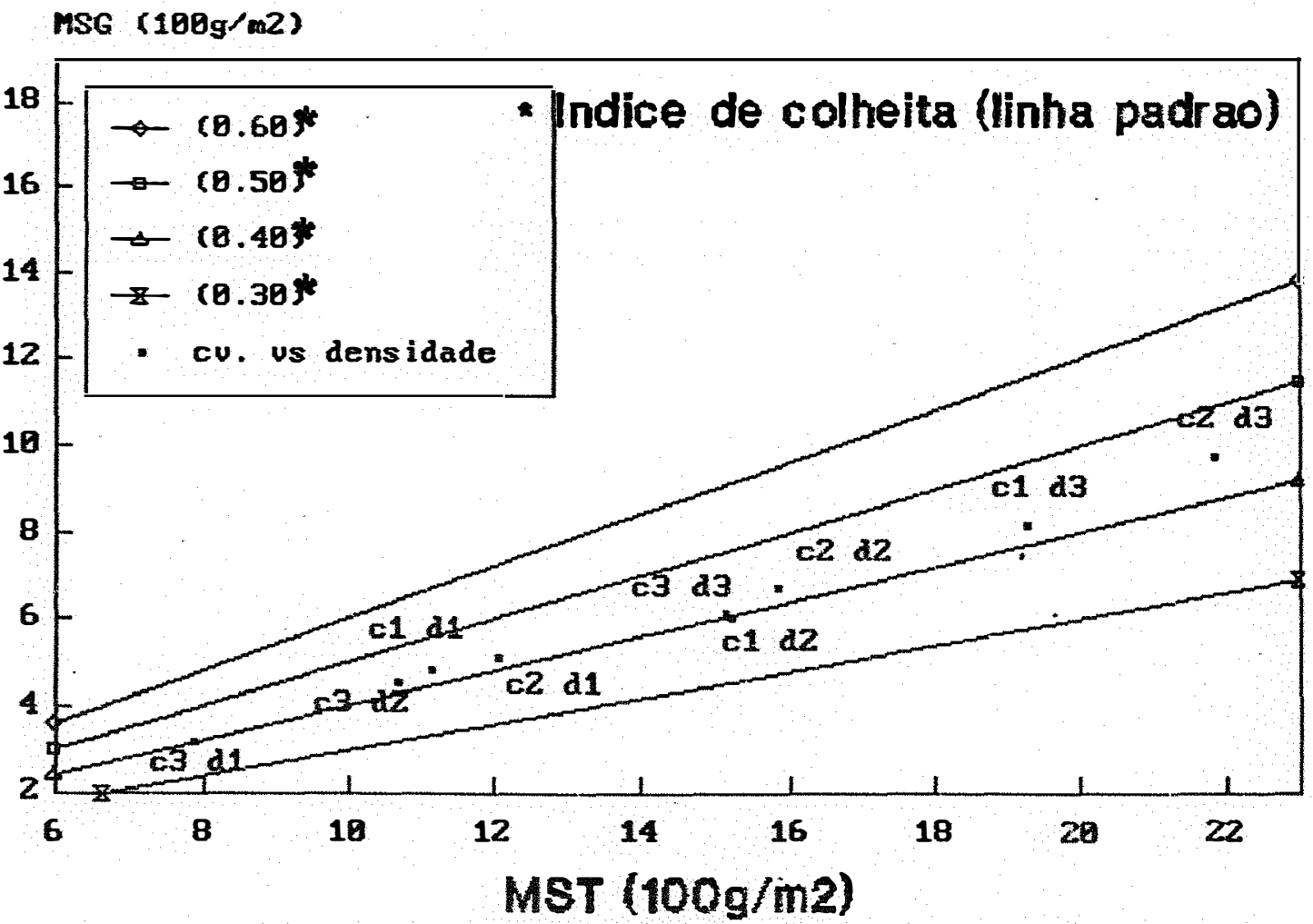

Figura 5 - Produções de matéria seca de grãos (MSG) e matéria seca total (MST), em $\mathrm{g} / \mathrm{m}^{2}$, de cultivares de milho de diferentes ciclos $(\mathrm{cl}=$ Normal, $\mathrm{c} 2=$ Precoce, c3 = Superprecoce), em três densidades de cultivo de safinha ( $d 1=33,3$ mil, $\mathrm{d} 2=55,5 \mathrm{mil}, \mathrm{d} 3=77,7 \mathrm{mil}$ plantas $/ \mathrm{ha}$ ). Piracicaba, SP. 1992.

$(0,60,0,50 ; 0,40$ e 0,30 são inclinações-padrão de linhas passando pela origem, que descrevem Índices de Colheita teóricos). 
Sendo o IC uma medida da eficiência do transporte de fotoassimilados para o grão, o maior IC observado por um cultivar demonstra major eficiência de conversão de produtos sintetizados em material de importância econômica. Comparandose os resultados de IC e rendimento de grãos (Tabela 8) alcançados pelos cultivares $\mathrm{cl}$, c2 e c3, na maior densidade de cultivo (d3), observa-se que o cultivar c2 obteve maior IC $(0,45)$ que os cultivares c1 $(0,42)$ e c3 $(0,41)$. Entretanto, nem sempre o maior IC está associado ao maior rendimento de grãos. Isto é o que se observa, por exemplo, nos tratamentos $\mathrm{cld} 1$ e cld3, dentro de cultivar; e, cld3 e c3d2, entre os cultivares cl e c3.

JOHNSON \& MAJORS (1979), encontraram relação negativa entre o IC e o rendimento de grãos em soja, estando o IC relacionado de maneira positiva com a matéria seca da planta. Em trigo, SINGH \& STOSKOPF (1971) mostraram o IC relacionado positivamente com o rendimento de grãos. DONALD \& HAMBLIN (1976) associaram o aumento do rendimento das culturas modernas de arroz, com os maiores IC apresentados por elas, com pequena variação no acúmulo de matéria seca, em comparação com os cultivares tradicionalmente usados pelos agricultores. 


\subsubsection{Avaliação do Índice de Colheita Genético (ICG) do milho}

O IC (determinado pela inclinação da linha que expressa o rendimento de grãos $x$ matéria seca total) para 0 milho apresenta significativa variabilidade (Tabela 7).

Tabela 7 - Valores do Índice de Colheita (IC) de milho

\begin{tabular}{|c|c|c|}
\hline \multirow{2}{*}{$\begin{array}{l}\text { Discriminação do material } \\
\text { Milho }\end{array}$} & Valor & Referências \\
\hline & & JAIN et al. (1976) \\
\hline (hibridos e variedades) & & \\
\hline Quênia & 0,10 & \\
\hline & $\begin{array}{l}0,34 \\
0,38\end{array}$ & \\
\hline Paquistão & $\begin{array}{l}0,38 \\
0,43\end{array}$ & \\
\hline Hungria & 0,48 & \\
\hline \multirow{2}{*}{ Iugoslávia } & 0,51 & \\
\hline & 0,53 & \\
\hline Romênia & 0,53 & \\
\hline Milho irrigado & 0,58 & FAIRBOURN et al. (1970) \\
\hline irrigado & 0,60 & RAUN et al. (1989) \\
\hline irrigado & 0,58 & VOORSHEES et al. (1989) \\
\hline não-irrigado & 0,54 & PETERSON et al (1989) \\
\hline & * Calculado de dados não \\
\hline & Sete Lagoas-MG & publicados de COELHO,A.M. \\
\hline $1988 / 89$ verão & 0,55 & (EMBRAPA/CNPMS. \\
\hline $1989 / 90$ verão & 0,49 & Lagoas, MG. 1993) \\
\hline $1990 / 91$ verão & 0,47 & \\
\hline inverno & 0,42 & . \\
\hline \multirow{2}{*}{\multicolumn{3}{|c|}{ Janaúba-MG }} \\
\hline & & \\
\hline 1990/91 verão & 0,48 & \\
\hline 1991 inverno & 0,48 & \\
\hline $1991 / 92$ verão & 0,53 & \\
\hline
\end{tabular}

(continua, Tabela 7) 
(continuação, Tabela 7)

\begin{tabular}{|c|c|c|c|c|}
\hline \multicolumn{3}{|c|}{$\begin{array}{l}\text { Discriminação do material } \\
\text { híbridos }\left(^{* *}\right) \text { não-irigado: }\end{array}$} & \multirow[t]{2}{*}{ Valor } & \multirow{9}{*}{$\begin{array}{l}\text { Referências } \\
{ }^{* *} \text { Calculado de ALESSI \& } \\
\text { POWER (1976) } \\
\text { (Dados: média de } 3 \text { anos) }\end{array}$} \\
\hline $\begin{array}{l}68 \text { dias } \\
\text { Sda semeadi }\end{array}$ & ra ao espiga & & & \\
\hline $\begin{array}{l}\text { espaçamento } \\
\text { da linha }(\mathrm{cm})\end{array}$ & $\begin{array}{l}\text { plantas/ha } \\
(1000)\end{array}$ & IC & & \\
\hline 100 & $\begin{array}{l}20 \\
30 \\
40 \\
60 \\
74\end{array}$ & $\begin{array}{l}0,45 \\
0,48 \\
0,44 \\
0,42 \\
0,39 \\
\end{array}$ & & \\
\hline 50 & $\begin{array}{l}20 \\
30 \\
40 \\
60 \\
74\end{array}$ & $\begin{array}{l}0,40 \\
0,45 \\
0,45 \\
0,41 \\
0,37\end{array}$ & & \\
\hline \multicolumn{3}{|c|}{$\begin{array}{l}85 \text { dias } \\
\text { (da semeadura ao espigamento): }\end{array}$} & & \\
\hline $\begin{array}{l}\text { espaçamento } \\
\text { da linha }(\mathrm{cm})\end{array}$ & $\begin{array}{l}\text { plantas/ha } \\
(1000)\end{array}$ & IC & & \\
\hline 100 & $\begin{array}{l}20 \\
30 \\
40 \\
60 \\
74\end{array}$ & $\begin{array}{l}0,40 \\
0,35 \\
0,34 \\
0,27 \\
0,28\end{array}$ & & \\
\hline 50 & $\begin{array}{l}20 \\
30 \\
40 \\
60 \\
74\end{array}$ & $\begin{array}{l}0,37 \\
0,35 \\
0,31 \\
0,30 \\
0,27\end{array}$ & & \\
\hline
\end{tabular}

* COELHO, A.M. Manejo da adubação potássica na cultura do milho, sob condições irrigadas. (EMBRAPA/CNPMS. IC calculado de dados não publicados, cedidos pelo pesquisador). Sete Lagoas, MG, julho/1993.

JAIN et al. (1976) obtiveram IC para líbridos e variedades sintéticas de milho em oito países das regiôes tropical e temperada, e encontraram valores médios variando de $9,9 \%$ (Quênia) a $53,4 \%$ (Romênia). Entre os maiores valores constam 52,8 (Espanha), 50,9\% (Iugoslávia), 47,9\% (Hungria) e 43,3\% (EUA). Entre os menores valores relevantes relacionados constam 37,5\% (Paquistão) e 34,4\% (Índia). 
O máximo IC para o milho está próximo de 0,60 , obtido em regiões temperadas. A Tabela 7 apresenta o limite superior de IC para milho de 0,60 (RAUN et al., 1989), 0,58 (FAIRBOURN et al., 1970; e, VOORSHEES et al., 1989). Para o cultivar BR 201, a inclinação da linha (passando pela origem) que expressa a máxima taxa de rendimento de grãos para a produtividade biológica é de 0,55 (Sete Lagoas, MG) e de 0,53 (Janaúba, MG).

\subsubsection{Efeito do ambiente no IC}

O efeito do ambiente no IC é ilustrado plotando o rendimento de grãos $\mathrm{x}$ matéria seca total. Possiveis razões do desvio do IC quanto ao ICG são discutidos.

A Figura 5 ilustra o efeito diferencial entre tratamentos (cultivar $\mathbf{x}$ densidade), confrontando com linhas-padrão, passando pela origem, e que representam diferentes inclinações, ou seja, diferentes IC, resultantes de avaliações de cultivos de milho, sob condições determinadas.

Para os dados de milho incluídos na Figura 5, IC com matéria seca total de $1.576 \mathrm{~g} / \mathrm{m}^{2}$ (IC =0,39) foi menor do que com $1.114 \mathrm{~g} / \mathrm{m}^{2}$ (IC =0,43), para o cultivar normal (c1). Observa-se que, entre cultivares, para os tratamentos que produziram quantidades semelhantes de matéria seca total (cld2 $=1.576 \mathrm{~g} / \mathrm{m}^{2} ; \mathrm{c} 2 \mathrm{~d} 2=1.583 \mathrm{~g} / \mathrm{m}^{2}$, c3d3 $\left.=1.511 \mathrm{~g} / \mathrm{m}^{2}\right)$, resultaram IC diferentes, sendo iguais a $0,39,0,43$ e 0,41 , respectivamente (Tabela 8).

Esta análise mostra que não é o támanho de planta, mas a natureza do estresse à planta que determina IC. STOCKLE \& CAMPBELL (1985) relataram que estresse hídrico durante a polinização de milho teve correlação negativa com IC, com alta significância $\left(r^{2}=0,98\right)$. 
Um aumento na população de plantas aumenta mais rapidamente a produção de matéria seca, além do que pode ser sustentada pela disponibilidade de água e luz pelo ICG durante o crescimento posterior.

Segundo VOLDENG \& BLACKMAN (1975) quando densidades são aumentadas, especialmente acima do nível em que o rendimento de grãos foi máximo, Índice de Colheita decresce.

Resultados experimentais tem mostrado que plantas pequenas ajustadas para estresse resultam em altos (ou mais altos) IC que plantas maiores. BOYER \& MCPHERSON (1975) mostraram que plantas podem se adaptar para dessecação de um modo que preservam a produção de grãos.

Os dados da Figura 5 mostram, entretanto, que os menores IC foram observados no cultivar Superprecoce, c3 (sobretudo nas menores densidades) e nas menores densidades para os cultivares Normal, c1, e Precoce, c2.

Os dados evidenciam a pouca adaptação do cultivar Superprecoce para plantio nas condições de safiinha, bem como apontam maiores rendimentos de grãos e de matéria seca total para maiores populações de plantas por hectare.

Correlações entre IC em um local e rendimento de grãos em outro, obtidos por DeLOUGHERY \& CROOKSTON (1979) sugerem que medidas de IC em um ambiente não deve ter relação com rendimento de grãos em um ambiente diferente. Isto certamente não estabelece que medidas de IC não são úteis para pesquisadores e geneticistas de plantas. Ao contrário, a caracterização do crescimento em termos de como a matéria seca é particionada deve continuar a ser um útil meio de avaliar a eficiência da produção de milho sob vários ambientes e sistemas de manejo. Os resultados de DeLOUGHERY \& CROOKSTON (1979) estabelecem, entretanto, que densidades de 
populações e particularidades ambientais devem ser levadas em consideração, quando da avaliação da informação do IC.

\subsection{Avaliação do Índice de Partição (IP)}

Na Tabela 8 são apresentados os resultados de $\mathbb{P}$ de milho, para os diferentes tratamentos.

As discussões desses resultados são apresentadas no item 4.8 (Interrelações de IC, IP e IER para milho, e suas relações com rendimento de grãos).

\subsection{Avaliação do Índice de Esforço Reprodutivo (IER)}

Na Tabela 8 são apresentados os resultados de IER para milho, para os diferentes tratamentos.

As discussões desses resultados são apresentadas no item 4.8 .

4.8. Interrelações do IC, IP e IER para milho e suas relações com o rendimento de grãos

A Tabela 8 apresenta os resultados de rendimento de grãos e os valores de IC, IP e IER para milho. 
Tabela 8 - Rendimento de grãos ( $\mathrm{kg} / \mathrm{ha}$, a $13 \%$ de umidade) e valores de Índice de Colheita (IC), Índice de Partição (IP) e Índice de Esforço Reprodutivo(IER) de cultivares de milho de diferentes ciclos $(\mathrm{c} 1=$ Normal, $\mathrm{c} 2=$ Precoce, $\mathrm{c} 3=$ Superprecoce), em três densidades de cultivo (d1 $=33,3 \mathrm{mil}, \mathrm{d} 2=55,5 \mathrm{mil}$, d3 = 77,7 mil plantas/ha). Piracicaba, SP. 1992.

\begin{tabular}{|c|c|c|c|c|}
\hline \multirow[t]{2}{*}{ Cultivar } & \multicolumn{4}{|c|}{ Densidade } \\
\hline & d1 & $\mathrm{d} 2$ & d3 & Média \\
\hline & \multicolumn{4}{|c|}{ Rendimento de Grãos (kg/ha, $13 \%$ ) } \\
\hline cl & $5.528,4$ & $6.927,4$ & $9.352,5$ & $7.269,4 \mathrm{~b}$ \\
\hline c2 & $5.837,3$ & $7.760,3$ & $11.189,9$ & $8.262,5 \mathrm{a}$ \\
\hline c3 & $3.653,0$ & $5.230,0$ & $7.029,0$ & $5.304,0 \mathrm{c}$ \\
\hline \multirow[t]{2}{*}{ Média } & $5.006,2 \mathrm{C}$ & $6.639,2 \mathrm{~B}$ & $9.190,5 \mathrm{~A}$ & \\
\hline & \multicolumn{4}{|c|}{ Indice de Colheita (IC) } \\
\hline cl & 0,43 & 0,39 & 0,42 & $0,41 b$ \\
\hline c2 & 0,43 & 0,43 & 0,45 & $0,44 a$ \\
\hline c3 & 0,41 & 0,43 & 0,41 & $0,42 \mathrm{ab}$ \\
\hline \multirow[t]{2}{*}{ Média } & $0,42 \mathrm{~A}$ & $0,42 \mathrm{~A}$ & $0,43 \mathrm{~A}$ & \\
\hline & \multicolumn{4}{|c|}{ Índice de Partição (IP) } \\
\hline cl & 0,76 & 0,75 & 0,79 & $0,77 \mathrm{~b}$ \\
\hline c2 & 0,81 & 0,80 & 0,83 & $0,81 \mathrm{~b}$ \\
\hline c3 & 0,99 & 1,02 & 0,90 & $0,97 a$ \\
\hline \multirow[t]{2}{*}{ Média } & $0,85 \mathrm{~A}$ & $0,86 \mathrm{~A}$ & $0,84 \mathrm{~A}$ & \\
\hline & \multicolumn{4}{|c|}{ Indice de Esforço Reprodutivo (IER) } \\
\hline c1 & 0,64 & 0,58 & 0,62 & $0,62 \mathrm{~b}$ \\
\hline c2 & 0,64 & 0,64 & 0,65 & $0,64 a$ \\
\hline c3 & 0,63 & 0,64 & 0,60 & $0,62 \mathrm{ab}$ \\
\hline Média & $0,64 \mathrm{~A}$ & $0,62 \mathrm{~A}$ & $0,62 \mathrm{~A}$ & \\
\hline
\end{tabular}

Médias seguidas da mesma letra não diferem entre si, ao nível de $5 \%$ de probabilidade, pelo teste de Duncan. Na coluna, comparação entre médias para densidade (letra minúscula); e, na linha, comparação entre médias para cultivar (letra maiúscula).

A análise de variância dos dados, para os índices IC, IP e IER, não apresentou diferença significativa, pelo teste de $F$, para densidades e interação cultivar $\mathbf{x}$ densidade.

Todos os três índices foram significativamente importantes $(\alpha=0,05)$ na explicação da variável rendimento de grãos. A análise de regressão múltipla dos dados apresentou os seguintes coeficientes de regressão parcial standard: IC $=0,86351$, IP $=-0,47299$, IER $=-0,49523)$. Observa-se, por esses coeficientes, que IC é mais 
relacionado com o rendimento de grãos. Em função das naturezas dos diferentes índices, isto é o esperado, dado que IC é a fração de grãos na matéria seca total. IC contribuiu com cerca de duas vezes mais que IP ou IER, na explicação do rendimento de grãos. IP e IER apresentaram-se com contribuição semelhantes, e negativamente relacionados com o rendimento de grãos.

Os cultivares apresentaram estratégias diferentes de produção. Essas estratégias são influenciadas pela interação genótipo $\mathrm{x}$ ambiente, refletindo o comportamento da planta nas fases vegetativa e reprodutiva. O cultivar Superprecoce, c3, apresentou IC e IER semelhantes aos respectivos índices dos cultivares c1 e c2; entretanto, apresentou IP com valores numéricos superiores.

WILSON (1982) relatou que cultivares superiores de milho podem usar uma variação de caminhos fisiológicos para obter alto rendimento. Isto sugere que um ideotipo universal não pode ser definido por um dado conjunto de condições ambientais. Segundo CROSBIE (1981), alguns "pool" de germoplasma utilizados em programas de melhoramento de milho tem diferentes frequências gênicas para várias características fisiológicas. Daí, é provável a existência de diferentes estratégias fisiológicas para altos rendimentos.

\subsection{Características morfológicas}

Na Tabela 9 são apresentados, por tratamento, os dados (média por planta) de altura de planta, número de folhas com limbo completamente expandido e de área foliar verde. 
Tabela 9 - Altura de planta (AP,.cm), número de folhas com limbo foliar completamente expandido (NFLE) e área foliar verde $\left(\mathrm{AF}, \mathrm{cm}^{2}\right.$ ), médias por planta, de cultivares de milho de diferentes ciclos ( $\mathrm{cl}=$ Normal, $\mathrm{c} 2=$ Precoce, $\mathrm{c} 3=$ Superprecoce), em três densidades de cultivo de safrinha ( $\mathrm{dl}=33,3 \mathrm{mil}$, $\mathrm{d} 2=$ 55,5 mil, d3 = 77,7 mil plantas/ha). Piracicaba, SP. 1992.

\begin{tabular}{|c|c|c|c|c|c|c|}
\hline \multirow[t]{2}{*}{ Trat. } & \multicolumn{2}{|c|}{ AP } & \multicolumn{2}{|c|}{ NFLE } & \multicolumn{2}{|r|}{ AF } \\
\hline & $77 \mathrm{DAS}$ & PMF & 77DAS & PMF & 77DAS & PMF \\
\hline cldl & $192,3 \mathrm{ab}$ & $197,8 \mathrm{~A}$ & $13,8 \mathrm{abc}$ & $13,0 \mathrm{~A}$ & $6.49,0 \mathrm{ab}$ & $776,1 \mathrm{AB}$ \\
\hline cld 2 & $203,5 a$ & $208,5 \mathrm{~A}$ & $14,3 \mathrm{ab}$ & $13,0 \mathrm{~A}$ & $7,38,7 \mathrm{a}$ & $1.306,9 \mathrm{~A}$ \\
\hline $\operatorname{cld} 3$ & $189,0 \mathrm{abc}$ & $209,8 \mathrm{~A}$ & $13,8 \mathrm{abc}$ & $13,0 \mathrm{~A}$ & $6.738,6 \mathrm{ab}$ & $272,3 \mathrm{~B}$ \\
\hline c2dl & $202,0 a$ & $205,0 \mathrm{~A}$ & $14,0 \mathrm{abc}$ & $13,0 \mathrm{~A}$ & $6.98,5 \mathrm{ab}$ & $849,3 \mathrm{AB}$ \\
\hline $\mathrm{c} 2 \mathrm{~d} 2$ & $196,5 \mathrm{ab}$ & $204,5 \mathrm{~A}$ & $14,0 a b c$ & $12,8 \mathrm{AB}$ & $6.784,2 \mathrm{ab}$ & 290,9 B \\
\hline $\mathrm{c} 2 \mathrm{~d} 3$ & $203,0 a$ & $204,5 \mathrm{~A}$ & $14,8 \mathrm{a}$ & $13,5 \mathrm{~A}$ & $6.646,5 \mathrm{ab}$ & $177,9 \mathrm{~B}$ \\
\hline c3dl & 1663 & $168,8 \mathrm{~B}$ & $13,3 \mathrm{bc}$ & $10,8 \mathrm{C}$ & $6.203,5 b c$ & $0,0 \mathrm{~B}$ \\
\hline c3d2 & 172,3 & $178,3 \mathrm{~B}$ & $14,0 \mathrm{abc}$ & $1], 3 \mathrm{BC}$ & $5.476,1 \mathrm{~cd}$ & $0,0 \mathrm{~B}$ \\
\hline$c 3 \mathrm{~d} 3$ & $181,8 \mathrm{bcd}$ & $183,0 \mathrm{~B}$ & 13,0 & $11,3 \mathrm{C}$ & $5.103,3 \quad d$ & $15,7 \mathrm{~B}$ \\
\hline $\operatorname{cv}(\%)$ & 6,33 & & 5,03 & & 10,06 & \\
\hline
\end{tabular}

Na coluna, médias seguidas pela mesma letra não diferem entre si, ao nível de $5 \%$ de probabilidade, pelo teste de Duncan. (Dentro da mesma coluna, letras minúsculas, comparação aos 77 DAS, e letras maiúsculas, no PMF).

Os cultivares normal (c1) e precoce (c2) apresentaram maior estatura média por planta (entre 189 a $204 \mathrm{~cm}$ ), diferenciando-se ao nível de $5 \%$ de probabilidade do cultivar superprecoce (c3), que apresentou estatura média por planta entre 166 a $182 \mathrm{~cm}$. Os cultivares c1 e c2 apresentaram aumento médio de porte no período entre 77 DAS e PMF (correspondente ao período de enchimento de grãos, PEG). O cultivar c3 praticamente não aumentou a altura nesse período.

Aos 77 DAS os três cultivares atingiram o número máximo de folhas com limbo completamente expandido. Nessa época, a área foliar atingiu valores próximos do máximo para todos os cultivares. 0 cultivar c3 apresentou menor área foliar verde, nesse período. No PMF, a área foliar verde dos três cultivares foi bastante reduzida, chegando a senescência completa no c3. Isto tem implicações marcantes na superficie foliar fotossinteticamente ativa, no período de enchimento de grãos. 


\subsection{Parâmetros morfofisiológicos}

\subsection{1. Índice de área foliar (IAF)}

Os dados de IAF são apresentados na Tabela 10.

Tabela 10 - Valores estimados de Índice de Área Foliar (IAF) de cultivares de milho de diferentes ciclos $(\mathrm{cl}=$ Normal, $\mathrm{c} 2=$ Precoce, $\mathrm{c} 3=$ Superprecoce $)$, em três densidades de cultivo de safrinha $(\mathrm{d} 1=33,3 \mathrm{mil}, \mathrm{d} 2=55,5 \mathrm{mil}, \mathrm{d} 3=77,7$ mil plantas/ha). Piracicaba, SP. 1992.

\begin{tabular}{|c|c|c|c|c|c|c|c|c|c|c|}
\hline & 21 & 35 & 49 & 63 & 77 & 91 & 105 & 119 & 133 & 147 \\
\hline cldl & 0,02 & 0,27 & 1,19 & 2,11 & 2,28 & 2,33 & 2,15 & 1,65 & 0,82 & 0,07 \\
\hline $\mathrm{cld} 2$ & 0,04 & 0,58 & 2,12 & 3,55 & 4,08 & 3,80 & 3,33 & 2,92 & 1,69 & 0,05 \\
\hline cld3 & 0,06 & 0,60 & 3,25 & 4,62 & 5,24 & 5,34 & 4,20 & 3,07 & 1,04 & 0,12 \\
\hline $\mathrm{c} 2 \mathrm{~d} 1$ & 0,03 & 0,34 & 1,42 & 2,43 & 2,30 & 2,27 & 2,15 & 1,27 & 0,28 & 0,06 \\
\hline c2d2 & 0,04 & 0,55 & 2,31 & 3,76 & 3,77 & 3,55 & 3,02 & 2,00 & 0,20 & 0,00 \\
\hline $\mathrm{c} 2 \mathrm{~d} 3$ & 0,06 & 0,92 & 3,00 & 4,80 & 5,17 & 4,69 & 4,52 & 1,58 & 0,42 & 0,00 \\
\hline c3dl & 0,02 & 0,25 & 1,27 & 2,00 & 2,07 & 1,91 & 1,36 & 0,38 & 0,03 & 0,00 \\
\hline c $3 \mathrm{~d} 2$ & 0,04 & 0,42 & 2,28 & 3,14 & 3,04 & 2,93 & 2,18 & 1,17 & 0,05 & 0,00 \\
\hline c $3 \mathrm{~d} 3$ & $\mathrm{O}_{2} 06$ & $0_{2} 64$ & 3224 & $4_{2} 18$ & 3297 & 4,23 & 2,76 & 1,03 & $\mathrm{O}_{2} \mathrm{Ol}$ & $\mathrm{O}_{2} \mathrm{OO}$ \\
\hline
\end{tabular}

O IAF expressa a área foliar, em estudos de comunidades vegetais, agrícolas ou não. IAF é a relação entre a área foliar total da planta e a área de solo disponivel a ela (WATSON, 1952).

Dessa forma, esse índice depende diretamente da área foliar atingida e observando-se a Figura $4(a, b, c)$, que mostra a evolução do IAF' em função do tempo, para os tratamentos (cultivar $\mathrm{x}$ densidade), nota-se que as curvas ajustadas para esse parâmetro seguem a mesma tendência das curvas ajustadas para a área foliar total. Assim como a área foliar, o IAF cresceu no início do ciclo vegetativo até atingir um máximo e a partir daí decresceu até a maturação das plantas.

Os valores máximos de IAF para os tratamentos foram atingidos próximo de 77 DAS, quando do início do período de enchimento de grãos. Para os três cultivares, os valores máximos de IAF foram obtidos nas maiores densidades. 
Conforme a Tabela 10, o maior IAF foi apresentado pelo tratamento cld3 $(5,3)$, sendo seguido pelo c2d3 $(5,2)$ e c $3 \mathrm{~d} 3(4,2)$.

No período de 77 DAS até 91 DAS a planta manteve a mesma área foliar, depois, devido ao fato de não acrescentar mais folha, o processo de senescência das mesmas foi o responsável pela diminuição da área foliar e, consequentemente o IAF diminuiu mais rapidamente, sobretudo no cultivar Superprecoce, c3. Decréscimos bem característicos do IAF foram obtidos para milho, por MACHADO et al. (1982).

Menores IAF máximos, dentro de cultivar, resultaram em menores rendimentos de grãos.

Verifica-se, na Tabela 5, que o cultivar c3 apresentou menor área foliar do que os cultivares c1 e c2, na maioria dos estádios de desenvolvimento; e, consequentemente, menor IAF. Por outro lado, esse cultivar teve maior capacidade de encher grãos, verificado pelo índice de partição (IP), Tabela 8. Isso leva à consideração de que a menor área foliar e o menor IAF atingidos pelo cultivar c3, em relação a c1 e c2, podem ser atribuídos ao menor número e tamanho das folhas do cultivar $\mathrm{c} 3$, pois sendo $\mathrm{o}$ IAF dependente da área foliar e essa, por sua vez, dependente do número e do tamanho das folhas, eles variaram em função de alterações ocorridas'em um ou nos dois componentes.

Apesar do cultivar c3 apresentar menor área foliar total e menor IAF, suas folhas são eretas (característica importante, principalmente quando se trabalha com altas densidades de plantas). Folhas eretas tendem a minimizar o autossombreamento, permitindo maior superficie iluminada e maior eficiência fotossintética no decorrer do desenvolvimento da cultura. Entretanto, sabe-se que folhas eretas somente são requeridas quando o IAF dessas plantas é grande, ou seja, maior área foliar ocupando adequadamente o espaço de solo disponível à planta. Porém, quando se avalia uma 
cultura no campo, nem sempre uma eficiência fotossintética baixa é prejudicial. Considerando-se a transpiração da planta, processo que ocorre simultaneamente à fotossíntese, e a evapotranspiração, muitas vezes as condições de autossombreamento diminuem a eficiência fotossintética da cultura, mas também diminuem a evapotranspiração. A evapotranspiração, na maioria dos casos, é mais prejudicial para a produtividade do que a diminuição da fotossíntese líquida. Isso ocome quando se trabalha com culturas onde o fator água é limitante; entretanto, como o fator hídrico foi razoavelmente disponível durante o ciclo da cultura, uma reduzida eficiência fotossintética pode ter influenciado negativamente a produtividade dos cultivares.

\subsubsection{Taxa de crescimento da cultura (TCC)}

A variação da matéria seca total da planta com o tempo, por unidade de área do terreno é chamada de taxa de crescimento da cultura (RADFORD, 1967).

A Tabela 11 mostra a duração do crescimento e a taxa de crescimento da cultura e dos grãos do milho, segundo os tratamentos utilizados, com ênfase no período de enchimento de grãos. 
Tabela 11 - Duração do Crescimento e Taxa de Crescimento da Cultura (TCC) e dos Grãos (TCG) de cultivares de milho de diferentes ciclos (c1 = Normal, c2 = Precoce, $\mathrm{c} 3=$ Superprecoce), em três densidades de cultivo de safrinha (d1 $=33,3 \mathrm{mil}, \mathrm{d} 2=55,5 \mathrm{mil}, \mathrm{d} 3=77,7 \mathrm{mil}$ plantas $/$ ha). Piracicaba, SP. 1992.

\begin{tabular}{|c|c|c|c|c|}
\hline \multirow[t]{2}{*}{ Trat. } & \multirow{2}{*}{$\frac{G D^{*}}{(\varnothing i-\varnothing \varnothing)}$} & \multicolumn{2}{|c|}{$\mathrm{TCC}^{* *}$} & TCG** \\
\hline & & (Sø-øi) & $(\varnothing i-\varnothing f)$ & (னі-бf) \\
\hline cldl & $440,76 \mathrm{a}$ & $6,084 \mathrm{c}$ & 9,934 cde & $7,271 \mathrm{de}$ \\
\hline cld2 & $417,42 \mathrm{a}$ & $9,924 a b$ & $13,230 \mathrm{abcd}$ & $9,701 \mathrm{~cd}$ \\
\hline $\operatorname{cld} 3$ & $440,76 a$ & $11,327 \mathrm{a}$ & $16,313 \mathrm{abc}$ & $12,481 \mathrm{~b}$ \\
\hline c2dl & $417,42 \mathrm{a}$ & $6,876 \mathrm{ab}$ & $11,187 \mathrm{bcde}$ & $8,124 \mathrm{~d}$ \\
\hline $\mathrm{c} 2 \mathrm{~d} 2$ & $394,08 \mathrm{a}$ & $9,286 \mathrm{ab}$ & $17,300 \mathrm{ab}$ & $11,300 \mathrm{bc}$ \\
\hline $\mathrm{c} 2 \mathrm{~d} 3$ & $417,42 \mathrm{a}$ & $12,638 \mathrm{a}$ & $19,658 \mathrm{a}$ & $15,540 \mathrm{a}$ \\
\hline c3dl & $417,42 \mathrm{a}$ & $5,876 \mathrm{c}$ & $5,263 \mathrm{e}$ & $5,047 \mathrm{e}$ \\
\hline c3d2 & $417,42 \mathrm{a}$ & $7,952 \mathrm{bc}$ & $7,405 \mathrm{de}$ & $7,147 \mathrm{de}$ \\
\hline $\mathrm{c} 3 \mathrm{~d} 3$ & $417,42 \mathrm{a}$ & $9,943 \mathrm{ab}$ & 11,952 bcde & $9,637 \mathrm{~cd}$ \\
\hline
\end{tabular}

Na coluna, médias seguidas da mesma letra não diferem entre si, ao nível de $5 \%$ de probabilidade, pelo teste de Duncan.

GD (graus-dia acumulados no período) $\mathrm{GD}(\mathrm{S} \varnothing-\varnothing \mathrm{i})=891,97$ unidades térmicas

TCC (Taxa de crescimento da cultura, em $\mathrm{g} / \mathrm{m}^{2}$.dia)

TCG (Taxa de crescimento de grãos, em $\mathrm{g} / \mathrm{m}^{2}$. dia)

(Sø-øi) (da semeadura, Sø até o início do período de enchimento de grãos, øi). Nesse estudo foi de 77 DAS, para todos os tratamentos (Vide Tabela 3) of (final do período de enchimento de grãos)

A TCC variou entre cultivares e densidades, nas duas épocas analisadas (Sø-øi, fase vegetativa, da semeadura até início do período de enchimento de grãos; e, no periodo de enchimento de grãos, øi-øf). Nas duas fases (vegetativa e reprodutiva) da planta a TCC tendeu a ser maior nas maiores densidades. Numericamente a TCC foi maior na fase reprodutiva, em relação à fase vegetativa para os cultivares $\mathrm{cl}$ e c2, nas três densidades de cultivo, e para o cultivar $\mathrm{c} 3$, apenas na maior densidade, $\mathrm{d} 3$.

Como a TCC demonstra a capacidade de produção de fitomassa da planta durante todo o desenvolvimento da cultura, espera-se realmente, que esses dois parâmetros mostrem tendências semelhantes. Inicialmente, a TCC é pequena, aumentando gradativamente até a maturação. MACHADO et al. (1982) trabalhando com quatro cultivares de milho, constataram decréscimo na TCC a partir do florescimento, 
enquanto que a planta continuou acumulando matéria seca até a maturação. A TCC foi influenciada pelos valores de IAF.

As taxas de crescimento da cultura (TCC) e de grãos (TCG) foram maiores nas densidades maiores, e refletem bem o rendimento dos diferentes cultivares. TCC e TCG maiores corresponderam a maiores rendimentos de grãos.

As funções logísticas (Anexos II e III) descreveram adequadamente as variações de peso da matéria seca total e do grão, dos cultivares, nas diferentes densidades.

\subsubsection{Taxa de crescimento de grãos (TCG)}

A variação da matéria seca de grãos no tempo, por unidade de área do terreno é chamada de taxa de crescimento de grãos. Os dados de TCG são apresentados na Tabela 11.

A TCG variou entre cultivares e densidades. TCG tendeu a ser maior nas maiores densidades de cultivo. O cultivar Precoce, c2, apresentou maiores valores numéricos de TCG, o que reflete os seus maiores rendimentos de.grãos, em relação aos cultivares c1 e c3.

As características genéticas e fisiológicas dos cultivares associadas com rendimento de grãos podem ser separadas nas que afetam a capacidade de armazenagem e naquelas que afetam a oferta de assimilados. Componentes identificados com a capacidade de armazenagem são grãos por espiga e peso de grãos por área de terreno, enquanto que a oferta total de assimilados é uma finção da duração e a taxa em que os assimilados são ofertados.

Peso de grãos atual, em contraste com o peso potencial, deve ser limitado pela oferta de assimilados e expressa o enchimento de grãos incompleto. 
Sendo a taxa de oferta de assimilados alta o suficiente para encher o grão completamente, a extensão da duração da oferta não pode ser ainda mais utilizada, como é o caso do milho (CROSS, 1975).

Todos os cultivares tiveram o enchimento de grãos incompletos, indicando inadequada oferta de assimilados durante o enchimento de grãos; sobretudo para o cultivar Superprecoce. Isto sugere que a oferta foi inferior à capacidade de armazenamento na espiga, e nesse caso, além do rendimento de grãos, outros órgãos vegetativos ficaram prejudicados em seu desenvolvimento.

\subsection{Graus-dia (GD) acumulados nos periodos vegetativo e enchimento de grãos}

A Tabela 11 mostra as variações médias de unidades térmicas para cada tratamento, no período de enchimento de grãos (øi-øf). Para todos os tratamentos foram computados 891,97 unidades térmicas para o periodo da semeadura até início do enchimento de grãos (Sø-øi).

\subsection{Considerações finais}

Os resultados desse trabalho são de experimentação de campo, conduzida na USP/ESALQ/Departamento de Agricultura, em Piracicaba, SP, em cultivo de "safrinha" (fev. a jul./1992), e integram um estudo que procura avaliar as relações entre fonte de assimilados e dreno, buscando-se fatores morfofisiológicos que limitam o rendimento de grãos em plantas de milho (Zea mays L.) de diferentes ciclos de cultivo, sob condições ambientais diversas (disponibilidades hídrica, térmica, de nutrientes e densidades de cultivo). 
Os rendimentos de grãos variaram entre os cultivares e entre as densidades, e foram significativamente superiores nas maiores densidades de cultivo, para os três cultivares.

Variações na densidade de cultivo resultaram em alterações morfológicas e fisiológicas nas plantas, sem praticamente modificarem a distribuição relativa de matéria seca entre os órgãos da planta. Observou-se uma compensação por área de terreno, resultando em maiores acúmulos de matéria seca total e de grãos, nas maiores densidades de cultivo, para os três cultivares.

As variáveis rendimento de grãos $(\mathrm{kg} / \mathrm{ha})$ e a componente número de grãos $/ \mathrm{m}^{2}$ de terreno apresentaram correlações positivamente altas para os diferentes cultivares. Essas correlações foram crescentes entre os cultivares Normal, Precoce e Superprecoce.

As taxas de crescimento da cultura (TCC) e de grãos (TCG) foram maiores nas densidades maiores, e refletem bem o rendimento dos diferentes cultivares. TCC e TCG maiores corresponderam a maiores rendimentos de grãos.

Os cultivares Normal e Precoce, nas três densidades de cultivo, e o cultivar Superprecoce, na maior densidade de cultivo, apresentaram TCC maior na fase de enchimento de grãos, em relação à fase vegetativa inicial (da semeadura até o início do período de enchimento de grãos).

A função logística descreveu adequadamente as variações de peso da matéria seca total e do grão dos cultivares, nas diferentes densidades.

Os três cultivares apresentaram comportamento similares para a variável área foliar verde. AF cresceu até um máximo, próximo do início do período de enchimento de grãos (øi), e daí decresceu até à maturação. O processo de senescência no cultivar Superprecoce, que se iniciou após o florescimento (ou início do período de 
enchimento de grãos), foi mais acelerado. Essa característica contribuiu para o menor acúmulo de matéria seca total e do grão, e consequentemente, para os menores rendimentos do cultivar, nas três densidades de cultivo.

Menores IAF máximos, dentro de cultivar, resultaram em menores rendimentos de grãos.

A função polinomial quadrática descreveu adequadamente as variações de área foliar verde dos cultivares, nas diferentes densidades.

Os cultivares apresentaram estratégias diferentes para produção. Essas estratégias são influenciadas pela interação genótipo $x$ ambiente, refletindo 0 comportamento da planta nas fases vegetativa e reprodutiva. O cultivar Superprecoce apresentou Índice de Colheita (IC) e Índice de Esforço Reprodutivo (IER) similares aos respectivos índices dos cultivares Normal e Precoce; entretanto, apresentou Índice de Partição (IP) com valores numéricos superiores.

Todos os cultivares tiveram o enchimento de grãos incompleto, indicando inadequada oferta de assimilados durante o período de enchimento de grãos; principalmente para o cultivar Superprecoce. Isto sugere que a oferta foi inferior à capacidade de armazenamento na espiga e, nesse caso, além do rendimento de grãos, outros órgãos vegetativos ficaram prejudicados em seu desenvolvimento.

Novas pesquisas devem dar sequência a esse estudo, nas seguintes linhas:

a) Interação genótipo $\mathrm{x}$ ambiente dos diferentes híbridos e variedades comerciais (em produção e promissores);

b) Avaliação dos componentes da variação genética e ambiental para as características desejáveis em cultivares de milho para plantio de "safinha":

b. 1) Com base no programa de melhoramento de populações;

b.2) Com base no programa de melhoramento de híbridos. 


\section{CONCLUSÃo}

A análise dos dados e a interpretação dos resultados do presente trabalho permitiram concluir:

As condições ambientais de cultivo de "safrinha" são subótimas para o desenvolvimento do milho, principalmente para os cultivares com características e comportamento de precocidade acentuada.

Para esse tipo de cultivo de "safiinha" deve-se dar preferência a materiais que tenham larga capacidade de dreno e que acumulem rapidamente matéria seca em seus órgãos, continuando ainda a acumular, paralelamente ao enchimento de grãos, matéria seca total. A redistribuição de assimilados após o início do periodo de enchimento de grãos é uma característica desejável. 


\section{REFERÊNCIAS BIBLIOGRÁFICAS}

ALESSI,J. \& POWER,J.F. Water use by dryland corn as affected by maturity class and plant spacing. Agronomy Journal, Madison, 68:547-50, 1976.

ALLISON,J.C.S. \& WATSON,D.J. The production and distribution of dry matter in maize after flowering. Annals of Botany, London, 30(119):365-81, 1966.

ALLISON,J.C.S.; WILSON,J.H.; WILLIAMS,J.H. Effect of partial defoliation during the vegetative phase on subsequent growth and grain yield of maize. Annals of Applied Biology, London, 81:367-75, 1975.

ASPIAZÚ,C. Pronóstico de fases en cultivos de maíz dentado mediante sumas de temperaturas. Revista de la Facultad de Agronomia y Veterinaria de Buenos Aires, 19(1-2):61-9, 1971.

ASPIAZÚ,C. \& SHAW,R.H. Comparison of several methods of growing-degree unit calculation for corn (Zea mays L.). Iowa State Journal of Science, 46:435-42, 1971. 
BADU-APRAKU,B.; HUNTER,R.B.; TOLLENAAR,M. Effect of temperature during grain filling on whole plant and grain yield in maize (Zea mays L.). Canadian Journal of Plant Science, 63(2):357-63, 1983.

BENINCASA,M.M.P. Influência de exposições norte e sul sobre parâmetros de crescimento de Sorghum bicolor. Jaboticabal, 1977. 149 p. (Livre-docência Faculdade de Ciências Agrárias e Veterinárias/UNESP).

BERLATO,M.A. \& SUTILI,V.R. Ecologia do milho: II. Determinação das temperaturas bases dos subperíodos emergência-pendoamento e emergência-espigamento de três cultivares de milho (Zea mays L.). In: REUNIÃO BRASILEIRA DE MILHO E SORGO, 11., Piracicaba, 1976. Anais. Piracicaba, ESALQ, 1976. p. 532-7.

BERLATO,M.A.; SUTILI,V.R.; CASTRO,A.O. Comparação de três métodos de cálculo das exigências térmicas para o espigamento de milho (Zea mays L.). Agronomia Sulriograndense, Porto Alegre, 10:87-94, 1973.

BOYERJ.S. \& McPHERSON,H.G. Physiology of water deficits in cereal crops. Advances in Agronomy, New York, 27:1-23, 1975.

BUNTING,A.H. \& DRENNAN,D.S.H. Some aspects of the morphology and physiology of cereals in the vegetative phase. In: MILTHORPE,F.L. \& IVINS,J.D., ed. The growth of cereals and grasses. London, William Clowes, 1966. p.20-36. 
BUREN,L.L.; MOCK,J.J.; ANDERSON,I.C. Morphological and physiological traits in maize associated with tolerance to high plant density. Crop Science, Madison, 14:426-9. 1974.

CALBO,A.G.; SILVA,W.L.C.; TORRES,A.C. Ajuste de funções não lineares de crescimento. Revista Brasileira de Fisiologia Vegetal, Londrina, 1(1):9-18, 1989a.

CALBO,A.G.; SILVA,W.L.C.; TORRES,A.C. Comparação de modelos e estratégias para análise de crescimento. Revista Brasileira de Fisiologia Vegetal, 1(1):1-7, $1989 b$.

CARDOSO,M.J. \& MUNDSTOCK,C.M. Comparação de treze métodos de cálculo de unidades térmicas de desenvolvimento de milho (Zea mays L.). Ciência e Cultura, 31(11):1278-83, 1979.

CODY,M.L. A general theory of dutch size. Evolution, Lawrence, 20:174-84, 1966.

CROSBIE,T.M. \& MOCK,J.J. Changes in physiological traits associated with grain yield improvement in three maize breeding programs. Crop Science, Madison, 21:255-9, 1981.

CROSS,H.A. \& ZUBER,M.S. Prediction of flowering dates in maize based on different methods of estimating thermal units. Agronomy Journal, Madison, 64:351-5, 1972. 
CROSS,H.Z. Diallel analysis of duration and rate of grain filling of seven inbred lines of com. Crop Science, Madison, 15:532-5, 1975.

DAYNARD,T.B.; TANNER,J.W; DUNCAN,W.G. Duration of the grain filling period and its relation to grain yield in com (Zea mays L.). Crop Science, Madison, 11:45$8,1971$.

DeLOUGHERY,R.L. \& CROOKSTON,R.K. Harvest index of com affected by population density, maturity rating, and environment. Agronomy Journal, Madison, 71:577-80, 1979.

DERIEUX,M.; BONHOMME,R.; DUBURCQ,J.B.; · RUGET,F.; VINCOURT,P. Influence du genotype et du lieu sur le nombre d'ovules presents a la floraison chez le mais. Canadian Journal of Plant Science, Ottawa, 63(2):371-5, 1983.

DONALD,C.M. In search of yield. Journal of the Australian Institute of Agricultural Science, Sydney, 28:171-8, 1962.

DONALD,C.M. \& HAMBLIN,J. The biological yield and harvest index of cereals as agronomic and plant breeding criteria. Advances in Agronomy, Madison, 28: 361$405,1976$.

DRAPER,N.R \& SMITH,H. Applied regression analysis. 2 ed. New York, J. Wiley, 1981. 709 p. ilust. 
DUNCAN,W.G. Maize. In: EVANS,L.T., ed. Crop physiology; some case histories. London, Cambridge Univ. Press, London. 1975, p. 23-50.

DUNCAN,W.G.; WILLIAMS,W.A; LOOMIS,R.S. Tassels and the productivity of maize. Crop Science, Madison, 7:37-9, 1967.

DURÃES,F.O.M.; MAGALHÃES,P.C.; OLIVEIRA,A.C.; FANCELLI,A.L.; COSTA,J.D. Partição de fitomassa e limitações do rendimento de milho (Zea maxys L.) relacionadas com a fonte-dreno. In: CONGRESSO BRASILEIRO DE FISIOLOGIA VEGETAL, 4., Fortaleza, 1993. Resumos. Fortaleza, SBFV;UFCE, 1993. Revista Brasileira de Fisiologia Vegetal, São Carlos, 5(1):1-120, jan/jun. 1993.

DUVICK,D.N. Continuous backcrossing to transfer prolificacy to a single-eared inbred line of maize. Crop Science, Madison, 14:69-71, 1974.

EASTIN,J.A. Leaf position and leaf function in corn - carbon-14 labeled photosynthate distribution in corn in relation to leaf function. In: ANNUAL CORN SORGHUM RESEARCH CONFERENCE, 24., 1969. Proceedings. p.81-9.

EDMEADES,G.O. \& DAYNARD,T.B. The development of plant-to-plant variability in maize at different planting densities. Canadian Journal of Plant Science, Ottawa, 59:561-76, 1979. 
EIK,K. \& HANWAY,J.J. Leaf area in relation to yield of corn grain. Agronomy Journal, Madison, 58:16-8, 1966.

EMPRESA DE PESQUISA, ASSISTÊNCIA TÉCNICA E EXTENSÃO RURAL DE MATO GROSSO DO SUL. Milho safrinha. Fato Rural. MILHO. junho/93. 4 p. (Boletim Informativo, 32), 1993.

EVANS,L.T. The physiological basis of crop yield. In: ed. Crop physiology; some case histories. London, Cambridge Univ. Press, 1975. p. 327-55.

FANCELLI,A.L. Influência do desfolhamento no desempenho de plantas e de sementes de milho (Zea mays L.). Piracicaba, 1988. 172 p. (Doutorado - Escola Superior de Agricultura "Luiz de Queiroz"/USP).

FAIRBOURN,M.L.; KEMPER,W.D.; GARDNER,H.R. Effect of row spacing on evapotranspiration and yield of com in a semi-arid environment. Agronomy Journal, Madison, 72:795-7, 1970.

FISHER,K.S. \& PALMER,A.F.E. Maize. In: SYMPOSIUM ON POTENTIAL PRODUCTIVTTY OF FIELD CROPS UNDER DIFFERENT ENVIRONMENTS, Los Baños, 1983. Proceedings. Los Baños, IRRI, 1983. p. 155-80.

FRANCIS,C.A; TEMPLE,S.R.; FLOR,C.A; GROGAN,C.O. Effects of competition on yield and dry matter distribution in maize. Field Crops Research, Amsterdam, 1:51-63, 1978. 
FREY,K.J. Improving crop yields through plant breeding. In: Moving off the yield plateau. ASA, 1971. (ASA Special Publication, 20).

FREY,N.M. Dry matter accumulation in kernels of maize. Crop Science, Madison, 21:118-22, 1981.

GERAGE,A.C. \& BIANCO,R A produção de milho na "safrinha". Informe Agropecuário, Belo Horizonte, 14(164):39-44, 1987.

GIFFORD,R.M. \& EVANS,L.T. Photosynthesis, carbon partitioning, and yield. Annual Review of Plant Physiology, Palo Alto, 32:485-509, 1981.

GILMORE,E.C. \& ROGERS,J.S. Heat units as a method of measuring maturity in corn. Agronomy Journal, Madison, 50:611-5, 1958.

GOLDSWORTHY,P.R. \& COLEGROVE,M. Growth an yield of higland maize in Mexico. Journal of Agricultural Science, Cambridge, 83:213-21, 1974.

GOLDSWORTHY,P.R ; PALMER,A.F.E.; SPERLING,D.W. GTowth and yield of lowland tropical maize in Mexico. Journal of Agricultural Science, Cambridge, 83:223-30, 1974.

HALLAUER,A.R. \& TROYER,A.F. Prolific com hybrids and minimizing risk of stress. In: ANNUAL CORN SORGHUM RESEARCH CONFERENCE, 27., 1972. Proceedings. p. 140-58. 
HANWAY,J.J. Corn growth and composition in relation to soil fertility. I. Growth of different plant parts and relation between leaf weight and grain yield. Agronomy Journal, Madison, 54:145-8, 1962.

HANWAY,J.J. \& RUSSELL,W.A. Dry-matter accumulation in corn (Zea mays L.) plants: comparisons among single-cross hybrids. Agronomy Journal, Madison, 61:947-51, 1969.

HARPER,J.L. \& OGDEN,J. The reproductive strategy of higher plants. I. The concept of strategy with special reference to Senecio vulgaris L. Journal of Ecology, London, 58:681-98, 1970.

HICKMAN,J.C. \& PITELKA,L.F. Dry weight indicates energy allocation in ecological strategy analysis of plants. Oecology, Berlin, 21:117-21, 1975.

HRSHFIELD,M.E. \& TINKLE,E.D. Natural selection and the evolution of reproductive effort. Proceedings of the National Academy of Science of the USA, Washington, 72:2227-31, 1975.

HOYT,P. \& BRADFIELD,R. Effect of varying leaf area by partial defolation and plant density on dry matter production in corn. Agronomy Journal, Madison, 54:523-5, 1962.

JAIN,H.K.; MUKERJEE,B.K.; SINGH,R.D.; AGRAWAL,K.N. The present basis future possibilities of breeding for yield in maize. Zeitschrift fur Pflanzenzuchtumg, Berlin, 76:90-101, 1976. 
JOHNSON,D.R. \& MAJORS,D.J. Harvest index of soybeans as affected by planting date and maturity rating. Agronomy Journal, Madison, 71(4):538-41, 1979.

KIRBY,E.J.M. The control of leaf and ear size in barley. Journal of Experimental Botany, 24:567-78, 1973.

LAMBERT,R.J. \& JOHNSON,R.R. Leaf angle, tassel morphology and the performance of maize hybrids. Crop Science, Madison, 18:499-502, 1978.

LOOMIS,R.S. \& WILLIAMS,W.A. Maximum crop productivity: an estimate. Crop Science, Madison, 3(1):67-72, 1963.

MACHADO,E.C.; PEREIRA,A.R; FAHL,J.I.; ARRUDA,H.V.; SII.VA,W.J.; TELXEIRA,J.P.F. Análise quantitativa de crescimento de quatro variedades de milho em três densidades de plantio, através de funções matemáticas ajustadas. Pesquisa Agropecuária Brasileira, Brasília, 17(6):825-33, 1982.

MAGALHÃES,A.C.N. Análise quantitativa do crescimento. In: FERRI,M.G. Fisiologia vegetal. São Paulo, EDUSP, 1979. v.1, p.331-50.

MAGALHÃES,P.C.; GAMA,E.E.G; MAGNAVACA,R. Efeito do despendoamento no comportamento e produção de alguns genótipos de milho. Sete Lagoas, EMBRAPA/CNPMS, 1993. 4 p. (EMBRAPA/CNPMS. Pesquisa em Andamento, 12). 
MEDERSKI,H.J.; MILLER,M.E.; WEAVER,C.R. Accumulated heat units for classifying com hybrid maturity. Agronomy Journal, Madison, 65:743-7, 1973.

MESSIAEN,C.M. Physiologie du developement chez Zea mays. Ann. Epiphyties 14:Hors scrie 11. 1963.

MONTGOMERY,E.G. Correlation studies of corn. S.1. Nebrasca Agricultural Station Annual Report, 24:108-159. 1911.

MOTA,F.S. Temperatura do ar e plantas cultivadas. In: ., Meteorologia Agrícola. São Paulo, Nobel, 1975. Cap. 8, p. 160-3.

MUNDSTOCK,C.M. Ciclo de crescimento e desenvolvimento de seis cultivares de milho em quatro épocas de semeadura. In: REUNIÃO BRASILEIRA DO MILHO, 8., Porto Alegre, 1970. Anais. p.18-29.

NEWMAN,J.E. Measuring com maturity with heat units. Cropś and Soil, 23(8):11-4, 1971.

PANE,R.T. The measurement and application of the calorie to ecological problems. Annual Review of Ecology Systematics, 2:145-64, 1971.

PALMER,A.F.E; HEICHEL,G.H.; MUSGRAVE,R.B. Patterns of translocation, respiratory loss, and redistribution of ${ }^{14} \mathrm{C}$ in maize labeled after flowering. Crop Science, Madison, 13:371-6, 1973. 
PEPPER,G.E.; PEARCE,R.B.; MOCK,J.J. Leaf orientation and yield of maize. Crop Science, Madison, 17:883-6, 1977.

PEREIRA,A.R. \& MACHADO,E.C. Análise quantitativa do crescimento de comunidades vegetais. Campinas, Instituto Agronômico, 1987. 33p. (IAC. Boletim Técnico, 114).

PETERSON,G.A.; WESTFALL,D.G.; WOOD,C.W. Crop and soil management in dryland agroecosystem. Fort Collins, Colorado State University, 1989. (Technical Bulletin, 89-3).

PLETT,S. Comparison of seasonal thermal indices for measurement of corn maturity in a prairie environment. Canadian Journal of Plant Science, Ottawa, 72:1157-62, 1992.

POEY,F.R.; GRAJEDA,J.E.; FERNANDEZ,O.J.; SOTO,F. Effect of detasseling on maize grain yield components. Agronomy Abstracts, p.44. 1977.

PRIHAR S.S. \& STEWART,B.A. Using upper-bound slope through origin to estimate genetic harvest index. Agronomy Journal, Madison, 82:1160-5, 1990.

PRINE,G.M. A critical period for ear development in maize. Crop Science, Madison, 11:782-6, 1971. 
RADFORD,P.J. Growth analysis formulae. Their use and abuse. Crop Science, Madison, 7:171-5, 1967.

RAUN,W.R.; SANDERS,D.H.; OLSON,R.A. Nitrogen fertilizer carriers and their placement for minimum till com under sprinkler irrigation. Agronomy Journal, Madison, 81:280-5, 1989.

RICHARDS,F.J. The quantitative analysis of growth. In: STEWARD,F.C. Plant physiology; a treatise. London, Academic Press, 1969. p.1-76.

SETTER, T.L. Partitioning of carbon among competing sinks. In: SHANNON,J.C.; KNIEVEL,D.P.; BOYER,C.H. ed. Regulation of carbon and nitrogen reduction and utilization in maize. Proceedings of the First Annual Pennsylvania State Symposium in Plant Physiology. ASPF. 1986. 372 p.

SILVA,W.J.; MONTOJOS,J.C.; PEREIRA,A.R. Análise de crescimento em dois híbridos simples de milho avaliada em duas densidades de população. Ciência e Cultura, São Paulo, 26(4):360-5, 1974.

SINGH,I.D. \& STOSKOPF,N.C. Harvest index in cereals. Agronomy Journal, Madison, 63(2):224-6, 1971.

SIVAKUMAR,M.V.K. \& SHAW,R.H. Methods of growth analysis in field-grown soya beans. Annals of Botany, London, 42:213-22, 1978. 
SNYDER,F.W. \& CARLSON,G.E. Selecting for partitioning of photosynthetic products in crops. Advances in Agronomy, New York, 37:47-72, 1984.

STEWART, G.A. High potential productivity of the tropics for cereal crops, grass forage crops, and beef. Journal of the Australian Institute of Agricultural Science, Sydney, 36:85-101, 1970.

STINSON,H.T. \& MOSS,D.N. Some effects of shade upon corn hybrids tolerant and intolerant of dense planting. Agronomy Journal, Madison, 52:482-4, 1980.

STOCKLE,C. \& CAMPBELL,G. A simulation model for predicting effect of water stress on yield: An example using corn. Advances in Irrigation, New York, 3:283$311,1985$.

TANAKA,A. \& YAMAGUCHI,J. Dry matter production, yield components and grain yield of the maize plant. Journal of the Faculty of Agriculture, Hokkaido University, Hokkaido, 57:71-132, 1972.

TEHLAN,RS.; SINGH,R.K.; SHARMA,S.C. Impact of growth and dry matter production pattern on yield of wheat. In: INTERNATIONAL WHEAT GENETICS SYMPOSIUM, 5., New Delhi, 1979. Proceedings. p. 1004-9.

TOLLENAAR,M. Sink-source relationships during reproductive development in maize. A review. Maydica, Bergamo, 22:49-75, 1977. 
TOLLENAAR,M. \& DAYNARD,T.B. Relationship between assimilate source and reproductive sink in maize grown in a short season environment. Agronomy Journal, Madison, 70:219-23, 1977.

TOLLENAAR,M. \& DAYNARD,T.B. Kernel growth and development at two positions on the ear of maize (Zea mays L.). Canadian Journal of Plant Science, Ottawa, 58:189-97, 1978.

VIDAL TORRADO,P. \& SPAROVEK,G. Mapa pedológico detalhado do Campus "Luiz de Queiroz", Universidade de São Paulo. Piracicaba, ESALQ, 1993. (escala 1:10.000).

VILLA NOVA,N.A; PEDRO Jr.,M.J.; PEREIRA,A.R.; OMETTO,J.C. Estimativa de graus-dia acumulados acima de qualquer temperatura base, em função das temperaturas máxima e mínima. Caderno de Ciências da Terra, Instituto de Geografia, USP, no. 30, 8 p. 1972.

VOLDENG,H.D. \& BLACKMAN,G.E. Interactions between génotype and density on the yield components of Zea mays. II. Grain production. Journal of Agricultural Science, Cambridge, 84:61-74, 1975.

VOORSHEES,W.B.; JOHNSON,J.F.; RANDALL,G.D.; NELSON,W.W. Corn growth and yield as affected by surface and sub-soil compaction. Agronomy Journal, Madison, 81:294-303, 1989. 
YAMAGUCHI,J. Varietal traits limiting the grain yield of tropical maize. IV. Plant traits and productivity of tropical varieties. Soil Science and Plant Nutrition, Tokyo, 20:287-304, 1974.

WATSON,D.J. The physiological basis of variation in yield. Advances in Agronomy, Madison, 4:101-45, 1952.

WILLIAMS,W.A.; LOOMIS,R.S; LEPLEY,C.R. Vegetative growth of corn as affected by population density. II. Components of growth, net assimilation rate and leaf area index. Crop Science, Madison, 5:215-9, 1965.

WILLIAMS,W.A.; LOOMIS,R.S.; DUNCAN,W.G.; DOVRAT,A.; NUNEZ,F. Canopy architecture at various population densities and the growth and grain yield of corn. Crop Science, Madison, 8:303-8, 1968.

WILSON,D. Breeding for morphological and physiological traits. In: FREY,K.J. ed. Plant Breeding II. Ames, Iowa State University Press, Iowa. 1982.

WILSON,J.H.; CLOWES,M.St.J.; ALLISON,J.C.S. Growth and yield of maize at different altitudes in Rhodesia. Annals of Applied Biology, 73(1):77-84. 1973.

WRIGHT,D.L.; GALLAHER,R.N.; TEARE,I.D: Tropical corn as a grain crop. In: TEARE,I.D. \& BROWN,E. od. Proceedings Southern Regional Tropical Corn Symposium. PPI; FAR;IFAS;University of Florida. 1991. p.28-30. 
WRIGHT,D.L.; TEARE,I.D.; KDD,B.T. Ontogeny of maize in relation to sequential cropping. Tropical Agriculture, Trinidad, 65(2):169-72, 1988. 
ANEXOS 
ANEXO I - Temperaturas médias do ar (máxima, minima e média, em ^o ${ }^{\circ}$, radiação solar média (cal. $/ \mathrm{cm}^{2}$ dia) e precipitação $(\mathrm{mm})$ ocorridas durante o periodo de Fevereiro a Julho de 1992. Piracicaba, SP. 1992. (Dados do Posto Agrometeorológico do Departamento de Física e Meteorologia da ESALQ, USP. Coordenadas geográficas: $22^{\circ} 42^{\prime} 30^{\prime \prime}$ de latitude sul, $47^{\circ} 38^{\prime} 00^{\prime \prime}$ de longitude oeste e 546 metros de altitude).

\begin{tabular}{|c|c|c|c|c|c|c|}
\hline \multirow[t]{2}{*}{ Período } & \multicolumn{3}{|c|}{ Temperatura $\left({ }^{\circ} \mathrm{C}\right)$} & \multirow{2}{*}{$\begin{array}{c}\text { Radiação } \\
\text { Solar } \\
\text { (cal./cm² dia) }\end{array}$} & \multicolumn{2}{|c|}{ Precipitação } \\
\hline & máx. & $\min$. & média & & (mm/alt.) & dias de chuva \\
\hline Fevereiro & 30,63 & 18,65 & 24,64 & 394,28 & 2,50 & 19 \\
\hline Março & 29,68 & 18,20 & 23,94 & 329,13 & 7,51 & 22 \\
\hline Abril & 28,00 & 15,92 & 21,96 & 334,33 & 2,66 & 10 \\
\hline Maio & 26,61 & 14,82 & 20,71 & 265,77 & 2,38 & 7 \\
\hline Junho & 27,02 & 12,39 & 19,70 & 277,37 & 0,02 & 1 \\
\hline Julho & 24,92 & 11,27 & 18,10 & 278,52 & 1,18 & 3 \\
\hline
\end{tabular}


ANEXO $\Pi$ - Coeficientes das equações $\left({ }^{*}\right)$ que descrevem a matéria seca total (MST, $\left.\mathrm{g} / \mathrm{m}^{2}\right)$ em função do tempo e respectivos coeficientes de determinação $\left(R^{2}\right)$, para cultivares de milho de diferentes ciclos $(\mathrm{cl}=$ Normal, $\mathrm{c} 2=$ Precoce, $\mathrm{c} 3$ $=$ Superprecoce), em três densidades de cultivo de safininha (dl $=33,3$ mil, $\mathrm{d} 2=55,5 \mathrm{mil}, \mathrm{d} 3=77,7 \mathrm{mil}$ plantas/ha). Piracicaba, SP. 1992.

\begin{tabular}{|c|c|c|c|}
\hline c1, cultivar Normal & $\mathrm{dl}$ & $\mathrm{d} 2$ & d3 \\
\hline $\mathbf{a}$ & 1161,1856 & 1603,6946 & 1892,0249 \\
\hline b & 155,6811 & 134,590 & 76,8777 \\
\hline k & 0,05736596 & 0,05828324 & 0,05165149 \\
\hline $\mathbf{R}^{2}$ & 0,95 & 0,94 & 0,93 \\
\hline SQtotal & 1828119 & 3606439 & 4575171 \\
\hline GLresiduo & 6 & 6 & 6 \\
\hline $\mathbf{N}$ & 10 & 10 & 10 \\
\hline & 441,5025 & 219,4389 & 419,723 \\
\hline SQresíduo & 24844,07 & 98608,91 & 65402,72 \\
\hline GLregressão & 3 & 3 & 3 \\
\hline QMresiduo & 4140,677 & 16434,82 & 10900,45 \\
\hline c2, cultivar Precoce & $\mathrm{dl}$ & d2 & $\mathrm{d} 3$ \\
\hline a & 1166,4464 & 1550,8898 & 2164,2271 \\
\hline $\mathrm{b}$ & 131,6108 & 201,274 & 112,3074 \\
\hline $\mathrm{k}$ & 0,05797175 & 0,06489967 & 0,05540982 \\
\hline $\mathbf{R}^{2}$ & 0,94 & 0,96 & 0,95 \\
\hline SQtotal & 1891124 & 3559259 & 6152031 \\
\hline GLresíduo & 6 & 6 & 6 \\
\hline & 10 & 10 & 10 \\
\hline & 314,7362 & 237,2834 & 562,9665 \\
\hline SQresíduo & 36051,61 & 90000,22 & 66633,07 \\
\hline GLregressão & 3 & 3 & 3 \\
\hline QMresiduo & 6008,601 & 15000,04 & 11105,51 \\
\hline c3, cultivar Superprecoce & dl & $\mathrm{d} 2$ & $\mathrm{~d} 3$ \\
\hline$a$ & 730,3093 & 1081,2770 & 1340,7698 \\
\hline b & 320,9604 & 199,092 & 168,8214 \\
\hline & 0,08040832 & 0,07294096 & 0,0716757 \\
\hline $\mathbf{R}^{2}$ & 0,95 & 0,95 & 0,95 \\
\hline SQtot & 863661,3 & 1802676 & 2739239 \\
\hline GLresíduo & 6 & 6 & 6 \\
\hline $\mathbf{N}$ & 10 & 10 & 10 \\
\hline $\mathbf{F}$ & 535,024 & 418,438 & 449,3583 \\
\hline $\mathrm{SQ}$ & 9685,488 & 25848,65 & 36575,34 \\
\hline GLregressão & 3 & 3 & 3 \\
\hline QMresiduo & 1614,248 & 4308,108 & 6095,89 \\
\hline
\end{tabular}


ANEXO III - Coeficientes das equações $\left(^{*}\right)$ que descrevem a matéria seca do grão (MSG, $\mathrm{g} / \mathrm{m}^{2}$ ) em função do tempo e respectivos coeficientes de determinação $\left(\mathrm{R}^{2}\right)$, para cultivares de milho de diferentes ciclos $(\mathrm{cl}=$ Normal, $c 2=$ Precoce, $c 3=$ Superprecoce), em três densidades de cultivo de safrinha $(\mathrm{d} 1=33,3 \mathrm{mil}, \mathrm{d} 2=55,5 \mathrm{mil}, \mathrm{d} 3=77,7 \mathrm{mil}$ plantas $/ \mathrm{ha})$. Piracicaba, SP. 1992.

\begin{tabular}{|c|c|c|c|}
\hline cl, cultivar Normal & dl & $\mathrm{d} 2$ & $\mathrm{d3}$ \\
\hline a & 451,4785 & 580,6478 & 792,6905 \\
\hline b & $1,057725 E+09$ & $4,245993 E+09$ & 9771679 \\
\hline $\mathbf{k}$ & 0,1838803 & 0,1967241 & 0,1375835 \\
\hline $\mathrm{R}^{2}$ & 0,99 & $1,011\left(^{* *}\right)$ & 0,99 \\
\hline SQtotal & 229198,9 & 381475,5 & 609391,9 \\
\hline GLresíduo & 2 & 2 & 2 \\
\hline $\mathbf{N}$ & 6 & 6 & 6 \\
\hline $\mathbf{F}$ & 279,8342 & 3979,323 & 14018,42 \\
\hline SQresíduo & 1638,105 & 191,7288 & 86,9416 \\
\hline GLregressão & 3 & 3 & 3 \\
\hline QMresíduo & 819,0526 & 95,8644 & 43,4708 \\
\hline c2, cultivar Precoce & dl & d2 & d3 \\
\hline$a$ & 493,1350 & 628,2588 & 930,8483 \\
\hline b & $1,053559 E+07$ & $1,63677 E+09$ & $3,067324 \mathrm{E}+07$ \\
\hline $\mathbf{k}$ & 0,1445242 & 0,1943112 & 0,1524528 \\
\hline $\mathbf{R}^{2}$ & 0,999 & $1,002\left({ }^{* *}\right)$ & 0,998 \\
\hline SQtotal & 245651,5 & 444350,8 & 896843,6 \\
\hline GLresíduo & 2 & 2 & 2 \\
\hline & 6 & 6 & 6 \\
\hline F & 488,9792 & 198,0367 & 1886,966 \\
\hline SQresíduo & 1004,752 & 4487,561 & 950,5666 \\
\hline GLregressão & 3 & 3 & 3 \\
\hline QMresiduo & 502,3762 & 2243,78 & 475,2834 \\
\hline c3, cultivar Superprecoce & d1 & d2 & d3 \\
\hline $\bar{a}$ & 295,8876 & 421,5240 & 547,1633 \\
\hline b & $4,548803 E+09$ & $6,261945 E+09$ & 2192585 \\
\hline $\mathbf{k}$ & 0,2075306 & 0,2144771 & 0,1389413 \\
\hline $\mathbf{R}^{2}$ & $1,040(* *)$ & $1,026(* *)$ & 0,98 \\
\hline SQtotal & 75777,46 & 193225,2 & 291298,2 \\
\hline GLresíduo & 1 & 2 & 2 \\
\hline $\mathbf{N}$ & 5 & 6 & 6 \\
\hline F & 613,8843 & 1841,854 & 528,4687 \\
\hline SQresíduo & 123,4393 & 209,8159 & 1102,424 \\
\hline GLregressão & 3 & 3 & 3 \\
\hline QMresiduo & 123,4393 & 104,908 & 551,2118 \\
\hline
\end{tabular}

* Função logística $w=a /\left(1+b e^{-k i}\right)$

* * Conforme DRAPER \& SMITH (1981), o critério dos quadrados mínimos gera

estimativas tendenciosas dos parâmetros de funções não lineares quando o número de pares de pontos é pequeno. Nesses casos, eventualmente, podem ocorrer estimativas de $\mathrm{R}^{2}>1$. 
ANEXO TV - Coeficientes das equações $\left(^{*}\right)$ que descrevem a área foliar (AF, $\mathrm{cm}^{2} /$ planta) em função do tempo e respectivos coeficientes de deterninação $\left(R^{2}\right)$, para cultivares de milho de diferentes ciclos (c1 $=$ Normal, $\mathrm{c} 2=$ Precoce, $\mathrm{c} 3=$ Superprecoce), em três densidades de cultivo de safiinha $(\mathrm{d} 1=33,3 \mathrm{mil}$, $\mathrm{d} 2=55,5 \mathrm{mil}, \mathrm{d} 3=77,7 \mathrm{mil}$ plantas/ha). Piracicaba, SP. 1992.

\begin{tabular}{|c|c|c|c|}
\hline cl, cultivar Normal & d1 & d2 & d3 \\
\hline a & $-2,241812$ & $-3,662002$ & $-4,745199$ \\
\hline $\mathrm{b}$ & 0,1044931 & 0,1739647 & 0,2305594 \\
\hline k & $-6,049011 \mathrm{E}-04$ & $-1,007268 E-03$ & $-1,36843 \mathrm{E}-03$ \\
\hline $\mathrm{R}^{2}$ & 0,95 & 0,96 & 0,94 \\
\hline SQtotal & 7,943833 & 21,88639 & 40,62541 \\
\hline GLresíduo & 7 & 7 & 7 \\
\hline $\mathbf{N}$ & 10 & 10 & 10 \\
\hline $\mathrm{F}$ & 143,0337 & 162,4691 & 107,9198 \\
\hline SQresíduo & 0,3887673 & 0,9429779 & 2,635086 \\
\hline GLregressão & & & \\
\hline QMresiduo & $5,553818 \mathrm{E}-02$ & 0,1347111 & 0,3764409 \\
\hline c2, cultivar Precoce & d1 & d2 & d3 \\
\hline$a$ & $-2,145536$ & $-3,316037$ & $-4,275737$ \\
\hline b & 0,1062498 & 0,1663918 & 0,2183645 \\
\hline k & $-6,369821 E-04$ & $-1,007826 \mathrm{E}-03$ & $-1,331844 \mathrm{E}-03$ \\
\hline $\mathrm{R}^{2}$ & 0,91 & 0,91 & 0,88 \\
\hline SQtotal & 9,056263 & 22,84715 & 41,3824 \\
\hline GLresíduo & 7 & 7 & 7 \\
\hline $\mathbf{N}$ & 10 & 10 & 10 \\
\hline $\mathbf{F}$ & 77,6089 & 75,91741 & 58,70909 \\
\hline SQresíduo & 0,8168373 & 2,106632 & 4,934105 \\
\hline GLregressão & & 2 & \\
\hline QMresíduo & 0,1166911 & 0,3009475 & 0,7048721 \\
\hline c3, cultivar Superprecoce & dl & d2 & d3 \\
\hline$a$ & $-1,605158$ & $-2,4888$ & $-3,165558$ \\
\hline b & 0,0402036 & 0,1318521 . & 0,1737994 \\
\hline $\mathbf{k}$ & $-5,214518 E-04$ & $-8,143174 \mathrm{E}-04$ & $-1,086174 \mathrm{E}-03$ \\
\hline $\mathrm{R}^{2}$ & 0,82 & 0,87 & 0,83 \\
\hline SQtotal & 6,980092 & 15,9501 & 30,20951 \\
\hline GLresíduo & 7 & 7 & 7 \\
\hline$N$ & 10 & 10 & 10 \\
\hline$F$ & 38,86863 & 53,09065 & 41,77798 \\
\hline SQresíduo & 1,257072 & 2,10302 & 5,061676 \\
\hline GLregressão & & 2 & 2 \\
\hline QMresiduo & 0,1795816 & 0,3004314 & 0,7230966 \\
\hline
\end{tabular}

* Função polinomial quadrática $\mathrm{w}=\mathrm{a}+\mathrm{b} \cdot \mathrm{x}+\mathrm{c} \cdot \mathrm{x}^{2}$ 
ANEXO V - Coeficientes de correlação entre as variáveis Rendimento de Grãos (RGPMF, em $\mathrm{g} / \mathrm{m}^{2}$, a $13 \%$ de umidade), Quantidade Total de Grãos, por Espiga (QTG/E), e Número de Grãos, por metro quadrado de terreno, por Tratamento $\left(\mathrm{NG} / \mathrm{m}^{2} / \mathrm{T}\right)$, de cultivares de milho de diferentes ciclos, em três densidades de cultivo de safrinha ( $\mathrm{d} 1=33,3 \mathrm{mil}, \mathrm{d} 2=55,5 \mathrm{mil}, \mathrm{d} 3=77,7$ mil plantas/ha). Piracicaba, SP. 1992.

a) cl, cultivar Normal

\begin{tabular}{lccc}
\hline & RGPMF (g/m $2,13 \%)$ & QTG/E & $\mathrm{NG} / \mathrm{m}^{2} / \mathrm{T}$ \\
\hline RGPMF $\left(\mathrm{G} / \mathrm{m}^{2}, 13 \%\right)$ & 1 & & \\
QTG/E & $-0,837$ & 1 & \\
NG/m $/ \mathrm{T}$ & 0,733 & $-0,713$ & 1 \\
\hline
\end{tabular}

b) c2, cultivar Precoce

\begin{tabular}{lccc} 
& RGPMF $\left(\mathrm{g} / \mathrm{m}^{2}, 13 \%\right)$ & QTG/E & $\mathrm{NG} / \mathrm{m}^{2} / \mathrm{T}$ \\
\hline RGPMF $\left(\mathrm{G} / \mathrm{m}^{2}, 13 \%\right)$ & 1 & 1 & \\
QTG/E & $-0,679$ & 1 & \\
$\mathrm{NG} / \mathrm{m}^{2} / \mathrm{T}$ & 0,896 & $-0,641$ & 1 \\
\hline
\end{tabular}

c) c3, cultivar Superprecoce

\begin{tabular}{lccc} 
& RGPMF $\left(\mathrm{g} / \mathrm{m}^{2}, 13 \%\right)$ & QT $/ \mathrm{E}$ & $\mathrm{NG} / \mathrm{m}^{2} / \mathrm{T}$ \\
\hline RGPMF $\left(\mathrm{G} / \mathrm{m}^{2}, 13 \%\right)$ & 1 & & \\
QTG/E & $-0,315$ & 1 & \\
$\mathrm{NG} / \mathrm{m}^{2} / \mathrm{T}$ & 0,918 & $-0,129$ & 1 \\
\hline
\end{tabular}

